GISELLE LARIZZATTI AGAZZI

\title{
A Crise das Utopias: A Esquerda nos romances de Antonio Callado
}

Dissertação de Mestrado apresentada ao Departamento de Letras Clássicas e Vernáculas da Faculdade de Filosofia, Letras e Ciências Humanas da Universidade de São Paulo.

Orientador:Prof. Dr. Flávio Wolf de Aguiar

São Paulo

1998 
Para o Luiz, E para Mariana. 
Agradecimentos

Eu tenho muito a agradecer ao Flávio, meu orientador, pelo estímulo e pelas intenções sempre sabiamente traduzidos e, claro, pela sua incansável luta contra qualquer tipo de autoritarismo e intolerância.

Ao Tino e à Myrna, que me lançaram às veredas literárias da vida; e às irmãs, que não me deixam esquecer de que resistir é preciso.

Ao Briseido e à Vima, amigos do sempre, pelas horas de trabalho dedicadas, de maneira direta ou indireta, a este trabalho e pelas deliciosas conversas.

À Val, à Vivi, à Lu e à Ju e a todos os amigos que lutam para fazer de suas vidas um 'romance da aprendizagem'.

À família Buscapé, em especial, ao vô Antônio, que me ensina a ver, com seus 93 anos, as belezas de um mundo marcadamente cruel.

À FAPESP, que me outorgou bolsa para a realização da pesquisa e produção da Dissertação. 
Sumário

Introdução 2

1. A construção da utopia: Quarup, o "romance da aprendizagem" 13

2. A reciclagem das águas: Bar Don Juan, entre o "idealismo abstrato" e o "romance da aprendizagem" 95

3. A derrocada das utopias: Reflexos do Baile, a implosão do texto literário 137

O hino às avessas: Sempreviva, o "romantismo da desilusão" 173

Conclusão 223

Bibliografia 229 
1. Introdução

“Quero reverte, pátria minha, e para reverte me esqueci de tudo,

Fui cego, estropiado, surdo, mudo, Vi minha humildade morte cara a cara, rasguei poemas, mulheres, horizontes. Não te direi o nome, pátria minha, teu nome é pátria amada, é patriazinha. Não rima com mãe gentil.

Vives em mim como uma filha, que és" (Vinícius de Moraes, em Pátria minha) 
Há trinta anos do Ato Institucional de número cinco, vemos que os estudos sobre as décadas de 60 e 70 proliferam rapidamente. É como se durante o longo silêncio a que o país fora submetido pelo regime militar, as idéias tivessem sofrido um intenso processo de esterilização e nada mais tivessem a comunicar sobre a história do Brasil. E, só agora, quando o tempo cumpriu com a lenta e árdua tarefa de iluminar o passado, os estudiosos voltam-se para aqueles tempos impossíveis e descobrem o quanto ainda existe para ser dito.

Essa lacuna nos estudos e documentos sobre o período ditatorial não deixou, todavia, de ser sabotada pela ficção, que, como cabe a ela, não se rendeu à censura e ao desânimo que penetraram nas universidades, nos veículos de comunicação, nos sindicatos, nos partidos políticos, enfim, na casa de cada um dos brasileiros.

Por muito tempo, criou-se o hábito de estudar o período ditatorial a partir da produção cultural da época, o que era, às vezes, enriquecido por alguns depoimentos ainda tímidos de ex-presos, exilados e políticos cassados. É a partir da década de 80, quando a Lei da Anistia entra em vigor e a democracia parece querer acordar do sono intranquilo a que se entregara, que a literatura especializada debruça-se sobre os turbulentos anos do terror e começa a assombrar o imaginário das novas gerações com a descrição da inadmissível capacidade do poder repressor de violentar a nação brasileira.

Nesse contexto, Antônio Callado foi um dos escritores mais significativos do seu tempo exatamente porque resistiu e, por isso, impediu que os acontecimentos fossem traduzidos apenas pelo olhar autoritário dos governos. Com a sorte de poucos, Callado entrou na guerra contra a ditadura, aprendendo a sabotar as armadilhas do violento poder opressor e a 
insistir na esperança. Embora tenha sido preso em dois momentos diferentes, o autor conseguiu driblar as autoridades, para dedicar-se a pensar a sua época, a imaginar novos projetos utópicos 1 para o Brasil e a produzir a sua arte.

Os quatro romances analisados neste trabalho resgatam esse período da nossa história, que compreende desde a consolidação das Ligas Camponesas (Quarup, 1967) até os momentos que antecederam a declaração da Anistia ditadura (Bar Don Juan, 1971) e pela derrocada definitiva do imaginário utópico comunista (Reflexos do Baile, 1976)². As narrativas compõem, assim, uma tetralogia, já que as obras dedicam-se à compreensão e à análise crítica da luta das esquerdas contra o período ditatorial, o que se revela tanto no conteúdo quanto na estruturação das narrativas, conforme teremos oportunidade de demonstrar.

O movimento revolucionário é resgatado em diversos momentos, cada romance busca plasmar a situação posterior à tematizada no romance

\footnotetext{
${ }^{1}$ O termo 'utopia', no presente trabalho, não deve ser entendido como Marx e Engels queriam em seu Manifesto Comunista (São Paulo, ed. Boitempo, 1998), um projeto inatingível por não contemplar os meios e as transformações sociais, econômicas, políticas e culturais a serem conquistados pelo povo para viabilizar a sua concretização. O conceito de utopia aparece ligado ao que Fredric Jameson, em $\mathbf{O}$ inconsciente político. A narrativa como ato socialmente simbólico ( São Paulo, ed. Ática, 1992 ), evoca, quando o relaciona a um desejo coletivo:“(...)o desejo por um determinado objeto é, ao mesmo tempo, alegórico de todo o desejo em geral e do Desejo enquanto tal, em que o pretexto ou tema desse desejo, ainda não foi relativizado e privatizado pelas barreiras do ego, que ciosamente confirmam a experiência pessoal e puramente subjetiva dos sujeitos como mônadas, que assim separam." ( p. 159)

Em muitas situações, o termo 'utopia' será adjetivado. Dessa forma, há a 'utopia comunista', a 'utopia coletiva', ou mesmo 'utopia individual'. Tais adjetivações servem para descrever o momento pelo qual o romance ou o personagem atravessa, quando revela um profundo desejo, que pode ter sido ou não cercado por o que Jameson chama de 'barreira do ego'. Há, em outras situações, a descrição mais cuidadosa do que se quer traduzir com o termo 'utopia, a partir das definições gerais propostas pelo livro O que é utopia, de Teixeira Coelho (São Paulo, ed. Brasiliense, 1990 ). No geral, esse tipo de descrição ocorre, quando o desejo do personagem representa o desejo de um grupo. O trabalho também conta com muitas das observações feitas por Ernildo Stein, em Orfãos de Utopia. A melancolia da Esquerda (Porto Alegre, Ed. Universidade, 1996 - 2 ed. ), que muito contribuiu para o desenvolvimento de algumas análises. Por fim, resta advertir que todas essas informações são trabalhadas mais enfaticamente nos dois primeiros capítulos, já que houve a preocupação de não tornar o estudo muito repetitivo.

${ }^{2}$ As datas referem-se aos anos de publicação do romance.
} 
anterior. É como se o autor procurasse construir a memória histórica das esquerdas, registrando o que os historiadores não podiam registrar e dando voz àqueles que a imprensa devia ignorar. Por isso, a ficção de Callado não pode ser entendida como um pretexto para o entretenimento ou para o experimento artístico, ao contrário, a ficção de Callado deixa clara a necessidade de se desenvolver uma reflexão crítica sobre os acontecimentos nacionais.

Atualizados com relação a seu tempo, Quarup, Bar Don Juan, Reflexos do Baile e Sempreviva trazem à tona as experiências dos marginalizados pelo processo histórico e impedem que os projetos utópicos da esquerda sejam sugados pelos porões do DOI/CODI. Todavia, apesar da urgente necessidade de se construir um espaço (o espaço ficcional, já que os outros estavam ocupados pelo discurso monocórdico do poder) que desse projeção às vozes roucas dos revolucionários, Callado não poupa críticas às propostas e ao comportamento das esquerdas brasileiras, tantas vezes equivocados e inócuos.

Lidos em conjunto, os romances contam a derrota das esquerdas pela ditadura, contam a crise das utopias de esquerda, que se dá tanto pelas situações cruéis e desumanas a que os revolucionários foram submetidos, estraçalhando com as suas subjetividades, como pelo redemoinho de falsas imagens em que os homens se perderam por não encontrarem sentido em suas vidas pessoais, quando mais na luta coletiva.

Os quatro romances estudados de Antônio Callado colocam-se, assim, a serviço das circunstâncias sociais, históricas e nacionais, e apontam, ao mesmo tempo, para a necessidade da construção da memória histórica da esquerda e para a de repensar o imaginário utópico proposto por esse 
segmento. Em entrevista concedida à crítica literária Lígia Chiappini1, Antonio Callado revela a sua paixão pelo Brasil e o mais profundo desejo de ver a transformação da nossa sociedade:

"Voltando (da Europa), então, logo que pude, dei um jeito, como jornalista, de viajar pelo Brasil. Fui ao Xingu, conhecer os índios, e me deu uma paixão pelo Brasil e um desejo de ver essas coisas que o brasileiro raramente vê. De forma que Quarup é fruto desse deslumbramento, desse retorno ao Brasil. Assim, foi um livro em que eu tomei conhecimento dessa variada realidade, e tentei, senti necessidade de organizar o Brasil na minha cabeça de certa forma. Isso que, no início, era banhado de um certo otimismo, foi esmorecendo(...)... eu levei alguns anos projetando (o livro), escrevendo, mas quando eu acabei, aquela esperança de ver alguma coisa sair de um país tão grandde e tão variado como o Brasil já estava um tanto esquecida...(...)O Quarup, o Bar Don Juan e sobretudo o Reflexos do Baile (...), esse conjunto é que dá o meu projeto de escritor, que é evidentemente parte da minha vida. (...) Como você já viu, meus livros todos têm essa marca da realidade brasileira. Não são livros desligados nem do meio geográfico nem do Brasil político e social. Então, o meu projeto de escritor está, digamos, nesse ponto.2"

Esse projeto de Callado revela uma literatura engajada na formação de uma consciência revolucionária capaz de compreender as imensas disparidades sociais existentes no país e as suas várias faces. Para o autor, a esquerda deveria aprender com a realidade brasileira e ensinar, a partir da sua própria atitude no mundo, um caminho coerente e viável para a conquista de um outro projeto utópico, já que a busca da utopia comunista tornou-se

\footnotetext{
${ }^{1}$ Leite, Ligia Chiappini Moraes. "Entrevistas com Antônio Callado" ( In: Zilio, Carlos e outros. O Nacional e o

Popular na Cultura Brasileira (Artes Plásticas e Literatura). São Paulo, ed. Brasiliense, 1982 - p.p. 235 a 267)

${ }^{2}$ Idem, ibidem. ( p. 235,236)
} 
uma tragédia histórica. Não obstante, imaginar outros caminhos é, segundo o próprio autor, um esforço quase inglório:

"A menos que acontecesse, como pode ainda acontecer, uma coisa muito ines perada...porque aquela esperança de transformações, a partir das greves, dos movimentos estudantis... essa caiu. E, para começar o quê?Uma tremenda revolta popular, a partir da fila do feijão, ou coisa parecida? É muito difícil imaginar, porque o Exército brasileiro é muito bem organizado, o seu poderio de ataque e repressão é uma tremenda arma...de modo que custa ver como o pais vai sair desse atoleiro em que se meteu."1

O presente trabalho debruça-se sobre essa crise da utopia das esquerdas que os romances buscam traduzir e que se revela na composição dos personagens, do espaço do tempo e da própria estrutura narrativa. Para tanto, a reflexão sobre as obras tem como eixo fundamental a tipologia da forma romanesca descrita por Lukács, na Teoria do romance2, o que encaminhou este estudo para análise da trajetória do herói em cada um dos textos ficcionais.

A opção por essa teoria crítica deve-se ao fato de ela ser um instrumental bastante adequado e rico para a compreensão do tema explorado nesta dissertação, uma vez que a tipologia lukacsiana do romance obedece à proposta de uma estética realista voltada para a necessidade de se produzir uma obra artística capaz de promover no público leitor a conscientização da sua condição social e histórica e a politização, no sentido amplo do termo, da sua compreensão do mundo Lukács buscou, como Antônio Callado em sua ficção, construir uma crítica literária engajada no processo histórico, a partir

\footnotetext{
${ }^{1}$ Idem, ibidem. ( p. 236 )

${ }^{2}$ Lukács, Georg. Teoria do romance. ( Tradução de Alfredo Margarido ). Lisboa, ed. Presença, s/d.
} 
da elaboração de um olhar voltado para as possibilidades que a arte teria em transformar a consciência política dos homens.

Mesmo quando a narrativa ficcional foge à tipologia do romance proposta pelo crítico ( o "romance da aprendizagem", o "idealismo abstrato" e o "romantismo da desilusão"), o instrumental teórico fornecido pela Teoria do romance continua a ser de extrema importância, uma vez que nega a estética realista significa negar a construção dos romances que a perseguiram e, portanto, negar as suas propostas.

É o que ocorre em Reflexos do Baile, narrativa construída a partir de cartas, páginas de diários, bilhetes, todos escritos em uma linguagem cifrada e obscura e sem a explicitação dos receptores das mensagens. Na disposição desses fragmentos textuais, também não há nenhuma ordenação lógica, cabendo ao leitor o trabalho de propor alguma coerência para os caos que se apresenta. Sem dúvida, a elaboração dessa obra nega a estética realista e nega os dois romances anteriores Quarup e Bar Don Juan, ainda que ambos, em muitos momentos, superem algumas das limitações propostas na teoria do romance lukacsiana.

Contudo, o romance seguinte, Sempreviva, recupera muitas das categorias narrativas destruídas em Reflexos do Baile, como a construção mais definida do foco narrativo e dos personagens e a configuração menos fragmentada do espaço e do tempo. O romance é mais trabalhado, pois apresenta os elementos de coesão que em Reflexos do Baile faltam e o movimento do enredo é mais linear, já que os conflitos são, lentamente, explicitados. Sempreviva, como o próprio Callado afirma na entrevista citada anteriormente, procura recuperar a comunicabilidade com um público 
maior, sem, porém, abandonar algumas propostas experimentais, tais como a multiplicação de protagonistas e uma certa fragmentação nos discursos:

"Em Sempreviva eu procurei, digamos, manter tudo o que experimentei em fazendo Reflexos do baile, uma coisa mais aprofundada no sentido literário da coisa, mas com maior velocidade interna, deixando mais linear, como você estava dizendo. Em outras palavras, eu quis fazer um livro bem trabalhado mas que, ao mesmo tempo, as pessoas com um mínimo de paciência passassem dessa coisa estética do livro para aquilo que o livro quer dizer."1

Ao se voltar novamente para a busca de um romance mais realista e menos experimental ( como confirmam seus próximos livros, A Expedição Montaigne, Concerto Carioca e Memórias de Aldenham House ), Callado parece querer levar para os seus livros a atitude que crê ser essencial aos intelectuais de países que, como o Brasil, foram corrompidos pela fome e miséria da maior parte do seu povo:

"Eu acho que o intelectual no Brasil deveria ser muito mais humilde, como cidadão. A literatura dele ele pode fazer como quiser. O Brasil precisa das pessoas que saibam alguma coisa, que conheçam alguma coisa. E que tenham essa sensibilidade para refletir de certa forma o seu pais. E contribuir de certa forma para que ele pudesse sair desse atoleiro que é O Brasil é uma vergonha (...) Em todos os campos, artes, literatura, jornal, as pessoas estão começando a achar que o Brasil não pode continuar como está.Então aí me daria a esperança de que o intelectual, mais especificamente, o homem que escreve, portanto, que pensa... supõe-se, não? Quem escreve, pensa Que essas pessoas dessem uma contribuição muito maior. Porque o Brasil precisa da gente. A verdade é essa"2

\footnotetext{
${ }^{1}$ Op. Cit. ( p. 262 )
}

${ }^{2}$ Idem, ibidem (p. 258.259 ) 
É essa atitude do intelectual engajado na busca, incansável, de um projeto para o Brasil que se revela em seus quatro romances. O estudo de Quarup, Bar Don Juan, Reflexos do Baile e Sempreviva nesta dissertação explora a dimensão social enquanto estruturadora das narrativas, seguindo as orientações do crítico literário Antônio Cândido, em seu artigo "Crítica e Sociologia"1, que apontam para a possibilidade de os elementos externos à obra interferirem na sua economia, quando "o elemento social torna-se fator da própria construção artística, estudado no nível explicativo e não ilustrativo"2.

Porque em alguns aspectos as obras superam, como veremos, o olhar de Georg Lukács, na Teoria do Romance, usaremos outros autores e teorias críticas ao longo desta dissertação, a fim de que a análise procure não submeter as narrativas às limitações da teoria crítica luckasiana. Todavia, é fácil perceber que este estudo deixou à margem assuntos importantes dos romances, o que se deu pelo recorte horizontal aqui realizado, a crise da utopia das esquerdas em quatro dos textos ficcionais escritos por Antônio Callado.

Se, por um lado, para conseguir cumpri com tal recorte, houve um empobrecimento da interpretação das obras ( as quais, certamente, teriam uma proposta de análise mais adequada se fossem trabalhadas isoladamente), por outro, os capítulos desequilibraram-se com relação ao número de páginas que os compõe. O desequilíbrio se deu em função da variedade, maior ou menor, mais ou menos trabalhada, dos elementos oferecidos por cada romance para a exploração do tema da crise das utopias. Por exemplo,

\footnotetext{
${ }^{1}$ Cândido, Antônio. Literatura e sociedade: estudos de teoria e história literária. (7 ed. São Paulo, ed. Nacional. 1985 - p.p3-15)

${ }^{2}$ Idem, ibidem ( p.7 )
} 
Quarup cobre um período histórico amplo, além de um tempo longo da vida do protagonista, em oposição a Reflexos do Baile, que cerca o sequestro do embaixador norte-americano pelos revolucionários. Conforme se verá, a análise de Quarup rendeu mais do que a de Reflexos do Baile. Isso ocorreu não por causa de algum julgamento a respeito do valor artístico daquela obra sobre esta última, mas porque Quarup conta com muitos aspectos que, para serem devidamente valorizados e aproveitados na exploração do tema proposto, requereram uma leitura mais demorada.

Espera-se compensar tais desequilíbrios com um estudo dos romances suficiente para demonstrar a tese de que, lidas em conjunto, as obras revelam a crise da utopia das esquerdas nas décadas de 60 e 70 e de que isso se traduz na estruturação das narrativas - mais especificamente na trajetória dos protagonistas - e, não, no conteúdo específico de cada uma.

Antônio Callado não poupa o movimento revolucionário de críticas, porém não deixa de apontar para a generosidade e solidariedade de muitos dos homens que participaram da luta contra a ditadura. Callado não apenas resgata em seus romances a admirável resistência das esquerdas contra a repressão, como tece os fios da história dos oprimidos, para garantir que da memória do Brasil não se subtraiam as vozes daqueles que, de alguma maneira contestaram o poder.

O que se lê por trás da necessidade de se construir uma memória histórica brasileira insubordinável ao discurso monocórdico do poder é parte do projeto utópico que, dos romances, surge. É esta memória que, com efeito, revelaria as verdadeiras faces do Brasil, o que faria vir à tona as vocações dessa terra e os equívocos e crimes cometidos ao longo de todos os séculos que sucederam a colonização. A luta contra a ditadura não é, pois, uma luta 
contra um único regime que se estendeu por mais de dez anos, mas contra todos os governos opressores que mascararam os anseios da população e as torturas, morais e físicas, promovidas pelas elites políticas e econômicas. Nesse ponto, seria, então, possível imaginar os meios para a construção do novo devir: uma ordem social que contemplasse todos os grupos marginalizados do autoritário processo histórico brasileiro e que humanizasse as relações sociais, destruídas pelo violento curso dos acontecimentos nacionais e mundiais.

Para a conquista desse projeto, conforme veremos, Callado elege a figura feminina, pois a luta armada, eminentemente masculinizada por apropriar-se da linguagem violenta e egocêntrica utilizada pelos regimes militares, não contempla as múltiplas faces do Brasil e não pode combater o poderoso e amoral exército nacional, apenas provocá-lo ainda mais a violentar os oprimidos. As mulheres poderiam, no imaginário traçado pelos romances, gerar uma maneira de atuar na realidade brasileira eficiente, já que, assumindo uma postura generosa e entendendo a felicidade do outro como parta da sua, não perpetuariam em si o autoritarismo e a intolerância.

Antônio Callado sabe das dificuldade de o Brasil encontrar o caminho para um processo revolucionário, mas não se rende a elas. Ao contrário, ao engendrar em sua literatura as imagens de um pais derrotado pela dor, provoca o leitor a sentir a realidade brasileira e pensar nela, redescobrindo as tantas faces da nação dissolvidas nas noites de terror. Em meio a tantos sentimentos e reflexões, há de emergir a nova utopia. E a literatura cumpre, mais uma vez nas palavras do Professor Antônio Cândido, com a sua função social de humanizar os homens. 


\title{
1. A construção da utopia: Quarup, o 'romance da aprendizagem'
}

\author{
"Evolução \\ Todas as noites o sono nos atira da \\ beira de um cais e ficamos repousando \\ no fundo do mar. \\ O mar onde tudo recomeça... \\ onde tudo se refaz... \\ Até que, um dia nós criaremos asas. \\ E andaremos no ar como se anda em \\ terra." \\ (Mário Quintana, em Esconderijos do \\ $\underline{\text { tempo) }}$
}

"Liberdade, essa palavra que o sonho humano alimenta, que não há ninguém que explique e nem ninguém que não entenda." (Cecília Meirelles, em $\underline{\text { Romanceiro da Inconfidência) }}$ 
O primeiro capítulo do livro de Antônio Callado tem como eixo a preparação do protagonista, Padre Nando, no mosteiro onde lhe era atribuída a função de guardião de um santuário, para que realizasse sua verdadeira missão: fundar, no Xingu, uma Prelazia para a catequização dos índios, através da qual, sonhava Nando, construiria uma sociedade perfeita com base numa combinação de princípios religiosos e sociais.

Antes mesmo de tentar construir as condições necessárias para a realização do seu projeto utópico, o romance inicia-se com Nando em meio a uma crise existencial, porque teme não conseguir pôr em prática as teorias que há anos vinha estudando. O processo de preparação pelo qual o jovem padre passa é uma longa e sofrida aprendizagem que o coloca em contato com o mundo exterior à Igreja, antes desconhecido por ele, haja vista o isolamento em que os membros do mosteiro encontravam-se.

O modo de vida dos religiosos com os quais Nando convive representa o distanciamento da Igreja em relação à realidade nacional. É uma igreja voltada para si e para a vida depois da morte, como fica claro nas primeiras páginas do romance em que o padre, na cripta, cuida dos ossos dos frades e com eles conversa, num contato íntimo com as forças místicas.

É, porém, nesse isolamento, durante um intenso exercício místico, que surge o elemento que dará sentido ao mundo de Nando: Levendo, o estudante revolucionário que, ferido, entra no santuário em busca de refúgio, pois havia sido atingido por um tiro de raspão, ao, mais uma vez, participar de um movimento pela reforma agrária:

Levindo continuou a história da chegada da Polícia das arrogâncias de Zé Quincas e das condições de trabalho escravo que me impunha aos lavradores, mas Nando fitava 
com desalento a mancha de sangue no marfim ilustre da caveira franciscana. Uma profanação, o episódio de loucura e violência vindo desaguar no ossuário. O sangue de um jovem desmiolado a manchar quem só aguardava o sangue da Ressureição. Que tinha Levindo a fazer ali, santos Deus?" (p.p. 11-12)

A morte e o misticismo vividos cotidianamente pelo padre são drasticamente interrompidos por Levindo, o qual irá, ele mesmo, tornar-se, ao final do romance, um herói mítico: seu sangue revolucionário , simbolizando vida e transformação, irá opor-se aos ossos dos frades mortos e ao reacionarismo da Igreja. Pode-se dizer que a cena descrita acima condensa o sentido da viagem do protagonista ao interior do país, pois Nando fará do universo de Levindo - as suas utopias políticas ( a revolução socialista ) e pessoais ( o casamento com Francisca ) - o sentido da sua própria vida.

A partida para o Xingu que Nando, pressionado por seu superior, D. Anselmo, finalmente, realiza, representa a transformação da visão de mundo de parte significativa da igreja católica, que se voltará para os pobres 1 , e de seu próprio universo interior2. O movimento centrifugo dos religiosos e, consequentemente, das instituições eclesiásticas, dá-se pela necessidade de

\footnotetext{
${ }^{1}$ Essa postura da Igreja Católica teve início nos anos 50 e deu início ao que veio a ser conhecido como "Teologia da libertação". "A Teologia da Libertação foi uma ruptura teórica e prática com a teologia tradicional. Uma espécie de 'revolução copernicana' nas bases cristãs (...) Inspirada na vida de Cristo, a teoria vincula ser cristão com lutar por justiça social. Por isso, a partir da década de 70, militantes católicos participaram ativamente nas lutas democráticas no continente" (Revista Atenção!, ano 2 n. 9)

${ }^{2}$ Muitos padres, nas décadas de 60 e 70, ficaram convencidos de que o "capitalismo é 'intrinsicamente' mau porque "é o egoísmo socialmente institucionalizado, a idolatria pública do lucro pelo lucro, o reconhecimento oficial da exploração do homem pelo homem, a escravidão de muitos ao interesse e a prosperidade de poucos. (Dom Pedro Casldáliga)" (idem, ibidem.). Há, nesse período, uma profunda desagregação da igreja, haja vista a adesão de parte significativa da Igreja contra o poder ditatorial ( e contra a vontade do Vaticano ). (In: BOFF, Leonardo. Teologia do cativeiro e da libertação. 4 ed. Petrópolis. Vozes. 1985)
} 
desenvolver um trabalho junto às questões sociais, o que faz com que o sentido da História e o dos próprios símbolos religiosos sofram mudanças profundas.

O protagonista - como a ordem religiosa a que pertencia - parte de uma leitura do real em que o homem comum não é o sujeito da História, mas o objeto, e, por isso, deve submeter-se a um modelo de comportamento, pautado numa concepção de mundo masculinizada (porque regida pela razão) e martírica (porque prevê a salvação através do sofrimento).

O primeiro imaginário utópico de Nando projeta a fundação de um Paraiso terrestre no Xingu, segundo o modelo dos jesuítas das Missões, uma vez que julgava serem esses religiosos detentores de um saber que lhes fora atribuído por Deus. Ignorando os valores da cultura indígena, o jovem padre crê que a vida martírica que os jesuítas levavam nas Missões devia-se tão somente à necessidade dos índios de salvarem suas almas e aprimorarem seu modo de vida.

“_ Se amolo vocês com minhas histórias - disse Nando - prometo não voltar ao assunto. Mas palavra que eu gostaria de ver a República Comunista dos Guaranis estudada até pelo biologistas. Os jesuítas das Missões não aceleram a história de um povo. Aceleraram a evolução de um povo.” (p. 30)

É possível caracterizar essa primeira mentalidade utópica de Nando, segundo Teixeira Coelho1, como um 'sonho abstratamente utópico', uma

${ }^{1}$ Coelho, Teixeira. O que é utopia. São Paulo, Brasiliense. 1980. 9 ed. (p.p. 14 a 34) 
vez que, de maneira simplista, formula "emblemas do futuro, que arrancam soluções do passado para projetá-las, jogá-las para frente" sem, porém, considerar as possibilidades históricas da realização"1.

Padre Nando encontra-se passivo e distante das condições objetivas da realidade, fechado num universo rígido demais para que percebesse os absurdos do seu imaginário utópico. Porém, ao preparar-se para a viagem, torna-se necessário contatar outras pessoas que não seus antigos conhecidos do mosteiro, e é a partir desse momento que o protagonista começa a se questionar e a reconstruir seu olhar e suas utopias:

"Desde que D. Anselmo lhe dera permissão - mais do
que isto, lhe ordenara - que saísse do Mosteiro, que
fizesse relações com gente do mundo, Nando só ti-
nha encontrado uma paz séria e tranquila em Fran-
cisca, noiva de Levindo. O mais era o desmembra-
mento, o mundo entrando em filetes de distração por
todas as frinchas da fortaleza que ele fora anti-
gamente. A convivência com seus amigos ingleses
era, sem dúvida estimulante mas agora o levava
quase ao desespero, de tanto que o tirava de dentro
de si mesmo" ( p. 12 )

Segundo a tipologia romanesca de Lukács2, Padre Nando, nessa sua performance inicial, preencheria a descrição do que o crítico designa por 'idealismo abstrato': o 'indivíduo problemático'3 esquece a diferença entre

\footnotetext{
${ }^{1}$ Idem, ibidem ( p. 34 )

${ }^{2}$ Lukács, Georg. Teoria do romance. Trad. Alfredo Margarido. Lisboa. Editorial Presença. s/d. ( p.p 109-128 )

${ }^{3}$ Georg Lukács aponta para o fato de que o 'espírito fundamental do romance, aquele que lhe determina a forma, objetiva-se como psicologia dos heróis romanescos: esses heróis estão sempre em busca'. O 'sentido da vida' deixa de ser inerente à existência do indivíduo, e este parte para a sua busca, ainda que saiba da impossibilidade de reencontrá-la. A essa condição da construção do romance, Lukács define a categoria do 'herói problemático'. ( Idem, ibidem. P 65 a 110)
} 
'ideal' e 'ideia', entre o 'espírito universal e a alma individual', e parte cego para o mundo sem, contudo, compreendê-lo.

O protagonista mostra-se, nos primeiros momentos da narrativa, a-histórico, pois renega sua temporalidade na expectativa de que a sua alma seja salva e eternizada pelo plano divino, ao mesmo tempo em que se julga ser o eleito de Deus para fundar uma Prelazia no Xingu.

Em oposição a esse estado inicial, Nando irá transcorrer um longo percurso para aprender a ter a realidade enquanto parâmetro para as formulações dos seus projetos de vida, o que fará com que a narrativa venha a compor, na terminologia lukacsiana1, um 'romance da aprendizagem'.

A consciência de Nando transforma-se à medida que o conhecimento da realidade traz consequências para o seu universo interior. A perda dos antigos valores faz com que o protagonista inicie a busca de um sentido verdadeiro para a sua vida, assumindo, dessa vez, todos os seus conflitos e paixões humanas.

É nesse momento que se cristaliza na imagem que Nando tem de Francisca todo o seu ideal de mulher e de amor, do qual ele se afasta fisica e espiritualmente, ao se sentir impelido a usufruir, no segundo capítulo do romance, dos prazeres das drogas e do sexo.

A estruturação do romance em sete partes, sob sete subtítulos diferentes 'O ossuário', 'O éter', 'A maçã', 'A orquídea', 'A palavra', 'A praia' e 'O mundo de Francisca' -, determina 'sete mudanças profundas no universo romanesco que se dão, como veremos, em função das transformações na intimidade do protagonista ao longo da narrativa.

${ }^{1}$ Idem, ibidem. ( p.p. 155-183) 
Nando é o herói problemático que, em contato com a realidade brasileira, trilha os caminhos do autoconhecimento, uma vez que essa é a única maneira de não se anular diante de um mundo que lhe é vazio de significados. Quarup cumpre, então com as expectativas que a Teoria do romance tece sobre o romance moderno:

"O processo assim explicitado como forma interior
dor romance é a marcha para si do indivíduo proble-
mático, o movimento progressivo que - a partir de
uma obscura sujeição à realidade heterogênea pura-
mente existente e privada de significação para o in-
divíduo leva a um claro conhecimento de si."1

É essa pesquisa do 'eu' que leva o protagonista a ver suas primeiras utopias dissolvidas num passado arcaico e é a paixão por Francisca que o faz lutar pela revolução social, para, só ao final do romance, depois de um doloroso processo de aprendizagem, adquirir a consciência de que ele, assim como todos os homens, deve assumir o papel de sujeito da História do seu país.

Os conflitos vividos pelo personagem no primeiro capítulo do romance originam-se, pois, do confronto entre o contexto social e a sua intimidade, desestabilizados pelas influências dos seus recentes amigos: o casal de protestantes, Winifred e Leslie e de Levindo e Francisca. Os frequêntes diálogos que Nando Mantem com o grupo irão minar a sua fé e flagrar as fragilidades dos dogmas da Igreja Católica:

"Quase todos os dias, num obstinado exame de consciência, Nando procurava ver como per-

${ }^{1}$ Idem, ibidem. (p.90) 
dera o vácuo interior que antigamente a medidatação enchia como a água enche uma cisterna vazia." ( p. 16)

O foco narrativo funde a terceira pessoa ao monólogo interior técnica que se realiza ao longo de todo o romance com algumas variações que acompanham as mudanças da visão de mundo do protagonista, como veremos ocorrer nos capítulos subsequentes. Nesse primeiro momento, o narrador abandona o leitor à sorte das ações e sensações de Nando, arriscando, vez por outra, um comentário sobre as motivações interiores dos outros personagens. O narrador explora a construção do protagonista ora apenas expondo seus conflitos entre sua subjetividade e a realidade, ora levando o leitor a desconfiar desse padre que se quer tão resoluto diante de um universo extremamente complexo e diverso.

O caráter monolítico e olhar centralizador que o protagonista acreditava ter é, por isso, contradito pelo próprio narrador em cenas como as das intensas discussões que trata com seus amigos protestantes:

“_ Nós temos planos, eu e D. Anselmo, inclusive de um bom tratamento para você - disse Leslie.

Nando deu de ombro. Winifred sentiu um rubor de cólera.

_ Olhe - disse - já vi muita gente falhar no que empreende e muita gente tentar o evidentemente impossível. Mas esse espetáculo de um homem como você descobrir de repente que o que Deus deseja é que você atenda a campainha do Mosteiro, isso, Nando, não é nem burrice. É blasfêmia. É inventar um Deus idiota. Nando ficou mais branco ainda, mas sorriu. 
_ Foi a solução que encontrei, winifred. Não existe outra." ( p. 84 )

Os longos debates entre Nando e seus amigos, ao mesmo tempo em que chamam o leitor a refletir sobre as convicções do jovem padre, fazem com que ele mesmo seja objeto de seus intensos questionamentos. $\mathrm{O}$ desequilíbrio do universo do protagonista gera uma situação irônica ao extremo, uma vez que o protagonista percebe que o seu imaginário não corresponde à realidade e sente que todos os seus planos estão fadados ao fracasso.

Esse é, segundo Lukács, o 'caráter demoníaco do herói' ${ }^{1}$, que vive uma espécie de ironia do destino, da qual só se libertará mediante um longo aprendizado que deverá reconciliá-lo com a 'realidade concreta e social' Tal reconciliação entre as expectativas do protagonista e o contexto histórico em que vive, porém, não poderá fazer com que ele abandone de todo a situação irônica em que vive, uma vez que a ação social do herói depende de que "certas partes da realidade sejam idealizadas, romantizadas, e que outras sejam abandonadas à prosa como vazias de sentido ${ }^{3}$." . Caso contrário, Nando voltaria ao final da narrativa, ao seu estado inicial, pois que teria abandonado o impulso central da narrativa: a utopia.

Levindo é, no primeiro capítulo, o antagonista de Nando não apenas por disputarem o amor da mesma mulher, Francisca, mas, fundamentalmente, pelos interesses opostos que representam. Ao contrário das inquietações de Nando em relação a sua vida religiosa e da sua passividade em relação aos seus desejos utópicos, Levindo está convicto das utopias revolucionárias representadas pelo programa socialista-comunista e participa ativamente da

\footnotetext{
${ }^{1}$ Idem, ibidem. (p.p. 61-106)

2 Idem, ibidem. (p. 155)

${ }^{3}$ Idem, ibidem. (p. 163)
} 
luta pela queda do capitalismo. Se Nando anseia pela eternização da alma no plano divino ao mesmo tempo em que sabe estar longe de compreender a si e à vida terrena, pois sente esvair-se o sentido das suas primeiras utopias, Levindo tem em perspectiva um futuro historicamente determinado ${ }^{1}$, que deverá ser conquistado através da união dos oprimidos.

Lê-se, apesar das diferenças abissais entre os imaginários utópicos de Nando e de Levindo, que ambos têm no horizonte utópico a possibilidade de transformação da sociedade por um percurso martirizador. Os dois personagens acreditam ser ou um 'missionário de Deus' ou um 'arauto de todas as liberdades possíveis e imagináveis', ambos eleitos pelas forças místicas ou históricas, para mudar a sociedade através do sofrimento, assim como Cristo sofrera para salvar os homens.

Nando e Levindo acreditam ser, portanto, de uma maneira ou de outra, responsáveis por mudar o curso da história brasileira. E isso só seria possível conquistar, segundo a perspectiva utópica de ambos, depois de terríveis tormentos e dores.

Outro aspecto fundamental que se observa em ambas as utopias é a marginalização do princípio feminino, uma vez que tanto Nando como Levindo entendem a construção de uma outra sociedade através de ações conduzidas pela razão e pela determinação de uma disciplina rigorosa e violenta. Esse processo, fatalmente, obedeceria a uma conduta excludente, a qual submeteria muitas pessoas a uma ordem social incompatível com os princípios de solidariedade e igualdade: no caso do padre, a imposição da

\footnotetext{
${ }^{1}$ Nando, nesse primeiro capítulo, representaria os utópicos que foram duranmente criticados por Marx e Engels no Manifesto Comunista. As críticas deviam-se, basicamente, ao fato desses utopistas não considerarem quaisquer possibilidades de as próprias classes oprimidas terem iniciativa histórica para a sua emancipação. Marx e Engels acreditavam que a revolução aconteceria quando houvesse a politização da população, a qual teria a iniciativa de propor as necessárias transformações no sistema social e econômico.
} 
cultura dos brancos sobre a cultura indígena; no caso do comunista, a emancipação dos oprimidos via luta armada.

A construção de ambas as utopias não contaria, portanto, com aquilo que, segundo Jung $^{1}$, o feminino personifica, como as intuições proféticas, a sensibilidade, a faculdade de sentir a natureza e, fundamentalmente, a capacidade de doar-se e de amar indiscriminadamente. A esse dado, porém, a imagem da mulher em Quarup ( bem como nos romances subsequentes ) opõe-se radicalmente, pois é de Francisca e da própria Winifred que Nando extrai a coragem para seguir viagem e é por causa delas ( e de outras tantas mulheres ) que ele entende a necessidade de buscar o autoconhecimento e de rever sua conduta no mundo.

O universo feminino desempenha, pois, uma função essencial no que diz respeito à trajetória do herói e ao próprio desenvolvimento da narrativa, pois são as mulheres que proporcionam a Nando re-unir as partes fraturadas da sua alma, mostrando-lhe como fundir sua intimidade ao real.

Um episódio bastante significativo é o da perda por Nando das esperanças de conseguir ganhar coragem para ir ao Xingu, sentindo-se, diante dos seus projetos de vida, fracassado e profundamente desanimado. Não por coincidência, há pouco tempo Francisca partira para a Europa em companhia de seu pai, a fim de convencê-lo a aceitar a sua decisão, a contragosto da família, de casar-se com Levindo e de passar a lua-de-mel no Xingu, em busca do Centro Geográfico do Brasil:

\footnotetext{
"Nos poucos dias que o separavam do dia em que devia viajar para o Xingu, Nando viveu uma fe-
}

\footnotetext{
${ }^{1}$ JUNG. Carl G. e outros. O homem e seus símbolos. Trad. de Maria Lúcia Pinho. 3 ed. Rio de Janeiro. Nova Fronteira. s/d.
} 
bre. Francisca, bruscamente retirada, era sinal de nova aliança. Em matéria de vida mística Nando não tinha sequer entrado na fase humilde de purgação.” (p. 78)

O vazio que a partida de Francisca abre na alma de Nando detona seus temores em relação aos possíveis desejos sexuais que viesse a sentir pelas índias quando estivesse no Xingu. Tanto é o seu desespero que chega a desmaiar no ossuário e a necessitar dos cuidados de seus amigos protestantes. É nesse contexto que Winifred lança mão da sua intuição feminina e, solidária ao amigo, tenta resgatar sua vontade de viver e de lutar, oferecendo seu corpo ao gozo precoce do padre:

"Lá fora Nando imaginava a tarde solarenta e biliosa que se arrastava como sempre, no quarto raiava sanguínea e fresca a madrugada. Sentia o corpo dela nas mãos quase como se estivesse fazendo Winifred naquela hora, dos pés aos olhos, pela entreperna, pelos seios. Sanquínea e fresca a guerreira Winifreda. Quando parecia a Nando que um relativo e momentâneo hábito se criara e que ia ver Winifreda em pêlo com alguma naturalidade raiava sanguinea e fresca a madrugada.

_Meu amor, vem - dizia Winifred - De novo.

Vê se me espera agora.

E lá se ia sua calma entre fonte e fonte a fonte das lagoinhas e a fonte da rosa funda, vinofreya, vitiviniternura de ruiviroxas parreiras." 
A cena do amor físico descrita pelo discurso indireto-livre, em oposição ao amor espiritual que até então Nando experimentara, é fortemente marcada pela cor vermelha dos cabelos e dor pêlos de Winifred, assim como o foi a invasão da cripta por Levindo, ao derramar seu sangue sobre os ossos de uma caveira. $\mathrm{O}$ vermelho invade o protagonista, representando, ao mesmo tempo, a mulher e a violência, ambos, noinício do romance, rejeitados pelo pseudo-equilíbrio da paisagem inicial do mundo de Nando:

\footnotetext{
"Mais um pedaço de corredor aberto na pedra e a subida que ia dar no claustro revestido de azulejos azuis (...) Depois do pleno ar livre do pátio, o sol encharcando a branca fachada quinhentista. Outro dia enjoado e lindo, pensou Nando sentindo o sol escorrer feito melado pelos muros, lambuzando tudo. O céu azul como uma gamela de louça da índias emborcada em cima do mundo Coqueiros de palmas bordadas pelas rendeiras, tronco cinzelado por santeiros." ( p.18)
}

A experiência sexual de Nando coloca-o em contato com seus temores e faz com que os assuma, o que vem a descontruir seu universo e a desautomatizar a sua compreensão do mundo, rompendo, definitivamente, com seus valores antigos, A reinvenção de palavras para descrever as sensações de Nando ( "vinofreda, vitiviniternura de ruiviroxas parreiras") portua a sua profunda revolução interior, prevenindo o leitor das 
consequências que o descobrimento do prazer sexual terá nos próximos capítulos:

\begin{abstract}
"Nando abriu os olhos e ia se levantar para fugir quando ouviu a porcelana do mundo se esfarelane chiando nos ares feito areia que escorre de uma ampulheta quebrada. Desapareceu o céu de sempre. As estrelas fuzilaram nos confins sem fundo. Um feio mar escrespado ao contrário pelo vento cuspiu sal nos coqueiros que chupavam água pelas raízes para esporrar leite nos cocos.” (p. 89)
\end{abstract}

O mundo do protagonista, posto em ruínas, rompe com qualquer possibilidade de se recuperar a situação inicial do romance, o que não deixa outra opção a Nando senão partir para o Xingu. Vence, então, uma face da igreja que, naquele período, revelava-se contra a impossibilidade de os padres praticarem o amor físico.

É Hosana, padre do mosteiro que tecia duras críticas a D. Anselmo, o representante dessa tendência ao longo do primeiro capítulo. Apaixonado por sua prima, Hosana defende o direito dos padres de casarem-se e de manterem contato com a sociedade a sua volta - não de maneira mais ampla como deseja o revolucionário Januário, que acompanha as ações de Levindo e defende as causas dos oprimidos e as lutas coletivas - mas de maneira a atender as suas necessidades individuais e, como ele mesmo afirma, biológicas dos homens, abolindo a relação indissociável entre sexo e pecado da tradição cristã. 
Por um lado, Hosana mantém de maneira indireta um intenso diálogo com Nando, uma vez que questiona o voto de castidade, motivo central das angústias e da própria crise existencial do protagonista. Por outro, há o padre André, um homem obcecado pela segunda vinda do salvador, o que o leva a querer morar na cripta. Essas personagens figuratizam, de maneira quase caricatural, as profundas contradições vividas pela Igreja Católica a partir dos anos 60:

\begin{abstract}
“A religião em geral e a Igreja Católica, em particular, vivera nesta década um dos momentos críticos de sua história. Uma crise global que não poupou nenhum domínio - dogma, liturgia, hierarquia, sacramentos, teologia, fé, vocação - e chegou a ser comparada à que precedeu a Reforma Protestante."1
\end{abstract}

Padre Hosana e Padre André representam as duas opções que se impõem a Nando: a Igreja em contato com o mundo e a Igreja voltada apenas para a salvação após a morte. Os conflitos do protagonista estão, portanto, intrinsicamente ligados ao processo histórico pelo qual os religiosos passavam.

Os dois religiosos, Hosana e André, têm um final trágico: o primeiro não suporta a repressão do seu superior, D. Anselmo, sobre seus amores pessoais e acaba por assassiná-lo; e o segundo é internado em um manicômio. Em meio às vidas fracassadas dos padres e à equivocada história da igreja, padre Nando irá buscar uma saída mais equilibrada e lúcida para a sua vida. Ao assumir seus conflitos o protagonista inicia a descida em seu universo

\footnotetext{
${ }^{1}$ Os anos 60. A década que mudou tudo. Edições VEJA. Uma publicação da Revista Veja, da editora Abril. Org. Zuenir Carlos Ventura.
} 
interior para dai sair, depois de viver profundas dores, convicto de qual é o centro verdadeiro da sua existência.

Se Hosana e André representam o estado de degeneração da instituição eclesiástica, Nando representa a possibilidade de ruptura com essa história fracassada e de construção de um outro caminho para a igreja. Buscando no autoconhecimento princípios que o possibilitassem constituir um modo de vida compatível com sua intimidade de uma atuação social coerente com a História do País, o percurso de Nando aponta para a necessidade de a igreja rever sua história e reconstruir o seu modo de intervenção na sociedade segundo a realidade da maior parte dos brasileiros, marginalizados e empobrecidos.

A sabedoria e a solidariedade que as mulheres transmitiram para Nando tornaram viável a concretização da sua incansável busca do conhecimento de si e do Brasil. É pelo contato físico com Winifred que Nando torna-se capaz de libertar-se do mundo fechado do mosteiro, aproximando-se da natureza e compreendendo os seus instintos vistos, antes, como fantasmas da sua mente culposa. A experiência sexual faz com que o padre se torne apto a realizar a viagem para o Xingu que sempre desejara, mas que nunca tivera coragem.

Porém, é Francisca que, sem o saber, muda definitivamente os rumos da vida de Nando. Invadindo o mosteiro, local proibido às mulheres, para ilustrar um mural de azulejos com a história de Santa Teresa D'Avila, Francisca domina os pensamentos do jovem padre, que passa a amá-la de maneira obsessiva. No primeiro capítulo, o protagonista consegue racionalizar sua paixão e delegá-la ao plano espiritual, pois julga que seu amor por Francisca é como o amor dos santos por Deus, conforme se lia nos 
textos de Santa Teresa D’Avila um intenso exercício místico de devoção e adoração.

Nando pertencia à ordem franciscana, a qual se formou no intuito de negar as ordens já existentes. S. Francisco de Assis cumpriu, pois, a função de um reformador, bem como Francisca, cujo nome é sem dúvida uma referência ao santo, cumpre com relação à vida do padre. A "monja branca em açucena passada a limpo" é o elo fundamental entre o claustro e a realidade, pois, ao mesmo tempo em que permite ao protagonista uma relação mística com o mundo, leva-o, pouco a pouco, a assumir o prazer sexual e o desejo de transformar a realidade nacional.

A associação entre amor e revolução, sexo e transformação, será o eixo fundamental das utopias de Nando, o que vem a representar um imaginário que ganhou muitos adeptos a partir da década de 60, com a ampla divulgação das teorias ( revolucionárias ) freudianas. Hebert Marcuse ${ }^{1}$, retomando a observação de Freud de que o sexo é a mola da civilização, propõe a liberação sexual, entendendo que, com isso, os indivíduos, ao trilharem os caminhos do autoconhecimento e da plena satisfação pessoal, romperiam com a "coisificação em que as relações humanas se petrificaram", , aprimorando, consequentemente, as relações interpessoais e a própria vida em comunidade.

\footnotetext{
${ }^{1}$ MARCUSE, Hebert, Eros e civilização ( Uma interpretação filosófica do pensamento de Freud). $3^{\circ} \mathrm{ed}$. Trad. Álvaro Cabral. Rio de Janeiro. Zahar, 1956.

${ }^{2}$ Idem, ibidem. (p.217)
} 
É esse ideário utópico que começa a se desenhar no capítulo seguinte, “O Éter", embora ainda se apresente de maneira bastante prematura e incongruente, pois trata muito mais da deseducação de Nando e do amadurecimento da sua visão do mundo, do que propriamente da consolidação do seu desejo de transformar a sociedade.

As primeiras páginas da segunda parte surpreendem o leitor pela mudança brusca da ambientação do romance. Do espaço restrito do mosteiro e do convívio com pouquíssimas personagens, o protagonista passa ao Rio de Janeiro, onde tenta conseguir permissão para partir para o Xingu e onde se relaciona com um grupo de pessoas variadas e extravagantes, que representam a elite política e intelectual da cidade mais importante do país.

A cena inicial narra o prazer de Nando ao cheirar lança-perfume, uma vez que esse lhe proporciona o esquecimento de seus fracassos e uma intensa sensação de poder. O espaço interior do protagonista é implodido e uma cascata de imagens sobrepõem-se e substituem-se, rompendo com a relativa linearidade do tempo que o romance mantivera até então. É como se a narrativa quisesse imitar a fusão de tempos e de espaços que ocorre na mente dos usuários da droga:

"A imagens da vida giravam como lanterna presa a rodopiante bastão de bambu e cada imagem apagava com sua violência memória da precedente: toureiro de jaleco fagulhante, calção de rubis e rabicho de jacarandá polido, pajem andrógino, moço enfermo de velho terno de linho branco sem gravata,moreno pálido no fulgor insolente da paisagem, mandarim enunciando o segredo com forte articulação de mandíbulas mas sem som.” ( p. 94 ) 
O uso da onisciência múltipla ${ }^{1}$ por trechos mais longos, embora a narrativa continue a se desenvolver fundamentalmente, em torno do Padre Nando, liberta os personagens do filtro do protagonista e lhes proporciona maior autonomia. Cada personagem tem seu perfil definido por suas ações e pensamentos, dando ao leitor a possibilidade de interpretar as figuras construídas, sem passar, antes, pela compreensão e julgamento do padre. Essa democratização do foco narrativo vem acompanhada de intensificação das intervenções do narrador:

\begin{abstract}
"Quando se despediam viram Falua, Vanda e Sônio que chegavam à porta do edifício. Evidentemente tinham saído em seguida mas ainda cheirando éter pois pisaram a calçada cambaleantes e se sentaram no meio-fio. Sentaram bem juntinhos um do outro. Falua estendeu nos joelhos, como uma faixa, o lenço, apertou com vigor o gatilho do lança-perfume umedecendo o lenço, metódico como se pavimentasse uma estrada, e os três juntaram os narizes no lenço. Nando sentiu inveja." ( p.96)
\end{abstract}

A partir dessa multiplicidade de tempos e de focos narrativos, desenhamse todas as vidas que Nando rejeitou e o fascínio que elas exercem sobre ele. As sensações recorrentes em seu espírito são perseguidas pela linguagem, que procura traduzi-las na construção de quadros em que se somam recortes de imagens e de discursos, apresentados, porém, sem nenhuma lógica

\footnotetext{
${ }^{1}$ LEITE, Lígia Chiappini Moraes. O foco narrativo. São Paulo. ed. Ática. 1989. A autora faz uma sistematização da tipologia do foco narrativo segundo Norman Friedman.
} 
aparente. O narrador persegue os movimentos internos de Nando, mas não os organiza, ao contrário, cola-se ao protagonista e adquire a mesma consciência que ele tem sobre a sua subjetividade. Narrador e protagonista confundem-se e os conflitos vêm à tona:

"E Nando viu, viu, a forma que era estranhíssima mas era ele mesmo, uma espécie de fole ou de balão de berrantes listras coloridas, deitado em chão de barro vermelho, abrindo e fechando. Deitado e concentrado no esforço imenso de abrir e fechar, abrir e fechar,inspirar, expirar e ali estava tudo, a grande alegria capaz de se comunicar ao mais inanimado. Agora ele realmente ia..." ( p. 139)

Longe dos seus referenciais e com sua fé abalada, Nando quer esquecer-se do que outrora fora e libertar-se dos seus medos e tabus. A droga torna-se o meio mais fácil e imediato do protagonista desprender-se dos seus antigos valores para se entregar a uma busca de verdadeiros valores ou, como queria Ramiro Castanho, decadente diretor do Serviço de Proteção ao Índio, chegar ao fundo do seu próprio universo e descobrir-se a si mesmo.

Nando, na busca da sua verdade pessoal, vive os conflitos entre fé e ciência, entre a vida religiosa no mosteiro e a vida mundana no Rio de Janeiro. A grande cidade associa-se ao centro do poder político e econômico do país e a inserção de personagens como o comunista Otávio e o jornalista Falua, além de Ramiro Castanho, revela as tensões que o Brasil sofria em 
1954 com a corrupção moral dos homens do governo e com o fortalecimento dos grupos de oposição ao Presidente Getúlio Vargas. ${ }^{1}$

'O Éter' compõe uma problemática fundamental que perpassa todo o romance: o abandono em que o Brasil se encontra. Tanto a igreja quanto as elites, que deveriam trabalhar por um projeto de nação, encontram-se ensimesmados e submersos em crises pessoais, pois não conseguem encontrar sentido na caótica realidade brasileira. A camada governante vive num estado de entorpecimento, fugindo às responsabilidades sociais e tornando-se omissa diante de um poder que se vende às mais diversas formas de corrupção:

“- Isto não vai assim não, doutor. Um marmanjo e duas moças se empilecando de lança-perfume no meio da rua. Puxa! Onde é que nós estamos? Porre de éter na cara da gente!

- Pois é - disse Otávio - é o que todo mundo está fazendo.

- Que todo o mundo? - disse o tira.

- Desculpe seu investigador - disse o Falua - Se quiser me leve, mas deixe as moças. Foi uma doideira mesmo, como diz aqui o meu amigo.

- O Brasil está assim, seu detetive - disse Otávio Clorofórmio no lenço e depois cama para que te quero. Um país de porre.” ( p.p. 97 e 98 )

\footnotetext{
${ }^{1}$ SKIDMORE, Thomas. Brasil: de Getúlio Vargas a Castelo Branco (1930 - 1964). Trad. Ismênia T. Dantas e outros. 6 ed. Rio de Janeiro. Paz e Terra. 1979.
} 
O consumo de lança-perfumes e bebidas alcóolicas é a forma que as elites encontram para preencher o vazio do seu cotidiano, corrompido pelos vícios do universo burguês e pela diluição dos valores morais e da ética na briga pelo poder. Se, por um lado, o éter leva ao sentimento de liberdade e transcendência, o que tanto seduz Nando, por outro, essa vivência puramente subjetiva denuncia a debilitação do mundo objetivo, povoado por pessoas frágeis e omissas, que sobrevivem através da fuga do peso desse mundo. $\mathrm{O}$ Brasil vive o estigma de ser o país do futuro e as elites dançam sobre a imensa massa de marginalizados, que já aprendia a técnica do adiamento das esperanças.

A realidade nacional encontra-se totalmente desvinculada do universo burguês a vida de Ramiro Castanho ou de Falua é tão diferente da vida dos camponeses como o é a vida de D. Anselmo dos indígenas. A diferença entre as condições de vida da maior parte dos brasileiros e as da elite flagra a passividade em que as pessoas se encontram diante da desigual e injusta organização social.

À exceção de Otávio, o restante do grupo que se forma em torno de Ramiro Castanho ( Lídia, Sônia, Vanda e Falua ) assume grande distanciamento dos problemas brasileiros e não demonstra qualquer preocupação com um possível julgamento moral e ético de seus atos por parte da sociedade. O comportamento irresponsável que grupo tem em seu cotidiano lembra o estado de profunda euforia e disforia que o carnaval provoca na população de modo geral. O povo, porém, passados os quatro dias de festa, volta aos problemas cotidianos e à luta pela sobrevivência, enquanto a elite continua a desfrutar dos devaneios provocados pelas drogas. Enquanto Ramiro insiste no uso do éter para promover o autoconhecimento, Falua vê 
na droga uma função educativa, uma vez que liberta o homem da sua visão determinista do mundo e dos seus preconceitos para a compreensão das mais elaboradas abstrações.

Cria-se, em torno da viagem ao Rio de Janeiro realizada por Nando, uma situação paradoxal: o jovem padre dirige-se à capital brasileira por motivos de caráter social ( conseguir uma permissão para ajudar os indígenas do Xingu ), Mas isola-se nos vícios da camada governante e fica ainda mais distante da realidade do que quando estava no mosteiro, porque marginaliza os índios e o interior do país e ignora os compromissos e responsabilidades que assumira para a transformação social:

\footnotetext{
"Nando apenas sorria, mais discreto que os outros, mas sentia um estranho desejo de éter. Ainda bem que não havia lança-perfume ali! Tinha saudade até do cheiro, tão repelente logo de início, do dzim-dzim-dzim que precedia as visões coloridas.” ( p.p. 123, 124 )
}

Vanda, a sobrinha de Ramiro, entrega-se a Nando e doa toda a sua sexualidade, a fim de que ele conseguisse controlar seu gozo precoce. O que antes o padre via como um milagre, uma 'revelação informativa' enviada por Deus, para que ele vencesse o medo da nudez das índias e partir para o Xingu ( "Que milagre maior feito por intermédio de Winifred? (...) Podia agora chegar aonde queria. Podia inclusive voltar à castidade ferida uma ver."), torna-se uma prática prazerosa e um caminho para o autoconhecimento. O aprendizado sexual de Nando acontece paralelamente ao seu aprendizado das condições objetivas da realidade, um influenciando o 
outro: a liberdade interior do protagonista impele-o a buscar a vida em sociedade e vice-versa.

Nesse contexto, embora o protagonista questione sua fé e os dogmas da Igreja Católica, não abandona sua religiosidade, mas a modifica de acordo com sua própria consciência. Padre Nando passa a humanizar as relações que mantém com o plano divino, atribuindo a Deus muitas das 'armadilhas' que lhe aparecem na vida:

“... Nando apressado e já agora nas garras da nova angústia. A prova real assim tirada, Nando sentiu, para consolo seu, menos culpa no burlar seu voto de castidade. Usando de cautela, como Labão quando experimentava Jacó, o Senhor lhe permitira acesso à mulher. Mas lhe reservara uma surpresa.” (p.144)

O amor físico passa a ser perseguido por Nando como o meio de se chegar à raiz dos seus conflitos. Compreender a si mesmo torna-se, para Nando, condição fundamental para compreender a sociedade brasileira. O protagonista termina sua viagem ao Rio de Janeiro numa busca de si, absolutamente ensimesmado, porém ciente de que não conseguiria mudar a sociedade se não resolvesse as profundas contradições do seu mundo interior.

Depois de ter convivido com Ramiro, Otávio, e Falua, Nando parte desconfiado de que sua utopia estava bastante longe de poder concretizar-se, até porque passa a questionar a qualidade das propostas de vida dos cristãos para os indígenas. Porém, como ainda não compreendera a violência terrível e destruidora do homem branco sobre o povo indígena, bem como as 
diferenças abissais entre as duas culturas, mostra-se obstinado em relação à necessidade de levar adiante sua missão.

Em 'A Maçã', a recepção feita pelos índios a pedidos de Lídia, a psicanalista namorada de Otávio, forja uma situação adâmica em que Nando, embora ainda não conseguisse compreender os significados profundos da encenação de Adão e Eva às avessas, começa a vislumbrar os diferentes contornos da cultura indígena. Se em 'O Ossuário' e em 'O Éter' Nando centrava suas atenções apenas sobre si mesmo e sobre suas utopias, nesse terceiro capítulo o espaço é o do outro. Pouco a pouco, Nando desprograma seus antigos moldes de recepção e despe-se de suas verdades e de seus medos e inseguranças para recriar seu universo interior. Procura modificar, por isso, seu olhar sobre o mundo e sua inguagem, entranhando-se num outro código, em tudo alheio ao seu:

"Em longas caminhadas de beira-rio, em visitas aos índios camaiurá acampados à beira do lago, embrenhando-se na mata para ver um veado correndo na distância ou garças voando reto como flechas brancas disparadas da copa das àrvores, Nando ruminava $o$ plano e triturava nomes com veror. Takuxirrãe, suiá, txukarramãe, iarumá, miarrã."

( p. 167 ) 
O protagonista, ao reconhecer o esfacelamento da cultura indígena por causa das intervenções do homem branco, compreende, enfim, o quanto os ideais que tanto cultivara partiam de pressupostos absolutamente equivocados. É dessa inadequação entre o herói e o mundo e do reconhecimento de que a grande busca de um sentido para a vida está fadada ao fracasso que Lukács ${ }^{1}$ dis nascer o 'grotesco' no romance moderno. Esse 'grotesco' segundo o crítico, não se limita ao homem, mas se estende ao plano das idéias, pois aponta para as incongruências entre as ações dos homens propriamente ditas e os resultados que elas produzem. Como essas ações não se pautam em parâmetros objetivos, os resultados só encontram reflexo no mundo interior do protagonista e, não, como se esperava, no mundo exterior.

A consciência do fracasso faz com que o herói perca o seu centro, o eixo da sua conduta no mundo, e inicie uma nova busca do significado da vida. $\mathrm{O}$ romance, consequentemente, desloca o sentido da narrativa e as imagens apresentadas passam a ser o oposto do esperado por Nando: o Xingu é o avesso do Paraíso, e os índios, corrompidos e aviltados pelo homem civilizado, inspiram dor e piedade:

\footnotetext{
“Algumas mulheres já estavam acocoradas à porta das malocas, cercadas de crianças. Quase todas envelhecidas precocemente, os peitos caídos, mamados às vezes por crianças grandes, a sugarem de pé ao seio. Daquelas pobres mulheres tivera medo fundo." ( p. 155 )
}

${ }^{1}$ LUKÁCS. Georg. Op. cit. (p.p 111) 
Padre Nando, nesse capítulo, presentifica-se através de longos silêncios diante do que lhe é revelado. O foco narrativo torna-se mais expansivo, espaçando os monólogos interiores do protagonista e acentuando o registro das cenas em que ele se vê envolvido e dos debates a respeito da situação dos índios. Sensível aos acontecimentos, o jovem padre almeja realizar-se humanamente, bucando agora, concomitantemente, a sua verdade pessoal e a verdade social.

Embora o protagonista resista em abandonar sua utopia, elaborando planos alternativos que pudessem salvar o indígena e dar condições para a fundação da sonhada Prelazia, ela é minada por diversos aspectos relacionados à própria sobreviv^ncia da raça. A compreensão do choque entre as culturas e da situação de miséria e abandono em que vivem as tribos vira de pontacabeça a base da visão de mundo de Nando.

Há, neste capítulo, uma galeria de utopias, que devem ser entendidas não segundo o desejo de transformar a realidade a partir da constatação e aceitação das condições objetivas da realidade, mas segundo um intenso desejo íntimo de ver no mundo um sistema de ideias concretizado sem que se considerasse o processo para atingi-lo. A utopia casa-se, aqui, com a projeção de ideologias e não com a de uma revolução social, reforçando a clássica análise de Marx de que o pensamento utópico nao previa o momento de amadurecimento social e de politização das classes oprimidas, necessários para a construção de uma nova sociedade, mas representa um desvio da energia revolucionária para os ociosos anelos e satisfações imaginárias. 
Padre Nando, porém, irá reorganizar o pensamento utópico, como o fez Marcuse $^{1}$ ao associa Hegel e Marx, Freud e Schiller e recuperar a construção de uma utopia que contemple a coletividade num mundo capaz de proporcionar felicidade à coletividade. É Nando o único personagem que irá atravessar, ao final da narrativa, a esterilidade de ideário do grupo e assumir a utopia revolucionária das esquerdas das décadas de 60 e 70, imaginando as vias de concretização da sociedade comunista que se daria, inevitavelmente, pela luta armada.

Fountoura é o personagem que concretiza a utopia contrária à de Nando. Ao invés de integrar o indígena à civilização e educá-los segundo os códigos culturais do homem branco, Fontoura quer demarcar os terrenos e reservá-los exclusivamente para as tribos, a fim de isolá-las do resto do Brasil:

“- Sim, Magnífico - Disse o Fontoura- se fosse realizável.

E se fosse possível, de acordo com meus sonhos, estender aqui - e seu dedo passou como se abrisse uma vala pelo contorno do Parque - uma cerca de arame farpado.

- Arame farpado? - disse Nando.

- Sim - disse Fontoura - Eletrifica. Contra o Brasil.

- E educar os índios de que maneira? Que fazer deles?

Que espécie de gente?

- O Estado seria de índios, de bugres, do que eles são disse o Fontoura martelando as sílabas - Eu não quero

\footnotetext{
${ }^{1}$ In: Marcuse, Hebert. Eros e civilização. Uma interpretação filosófica do pensamento de Freud. Rio de Janeiro. Zahar. 1968. Marcuse, a partir da ideia da 'negação', organiza a ideia utópica enquanto meio de manter viva a possibilidade de construir um mundo qualitativamente distinto do nosso mundo. Quando o pensamento utópico relaciona-se a Nando, esse retoma a análise de Marcuse e aponta para o fato de ser viável a revolução social a partir da revolução individual, tomando a forma de uma inflexível negação de tudo o que existe. Quando relaciona-se aos demais personagens, o pensamento utópico atrofia-se e expressa apenas a satisfação e a felicidade pessoais.

É exatamente porque Nando tem sua felicidade individual negada - não se satisfaz espiritualmente, pois a vida mística já não lhe basta, e tampouco sexualmente, porque não consegue reter o prazer - que lhe é possível enxergar a necessária busca da felicidade coletiva.
} 
transformar índios em nada. Parques imensos, cuidadosamente vigiados, fizeram os ingleses para girafas e zebras em Quênia e Tanganica. Não para educar girafas ou zebras. Para preservá-las vivas.”( p.p. 160-161 )

O imaginário utópico de Fontoura tem uma estreita relação com o de Nando, na medida em que ambos agonizam diante do fato de não considerarem as condições objetivas da realidade. Fontoura e Nando mantêm o quanto podem suas perspectivas utópicas, mesmo sabendo que elas estão fadadas ao fracasso. Fontoura reforça a distância entre 'ideal' e 'idéia' já apontada em Nando, contribuindo para a construção do grotesco ${ }^{1}$, que vem a evidenciar os equívocos dos projetos voltados à transformação da sociedade.

As fragilidades dos projetos utópicos traduzem a falta de maturidade dos homens diante das complexas questões sociais. Fontoura não consegue propor uma saída para os índios dentro do contexto sócio-econômico brasileiro deseja voltar a um passado idealizado, discriminando, dessa maneira, as outras populações interioranas. O processo de exclusão é, para Fontoura, fundamental, bem como o era para Nando, uma vez que pensava serem os indígenas o povo eleito.

O que marca a diferença fundamental entre o padre e o funcionário público é o amadurecimento do ideário de Nando ao longo do romance. Fontoura morre devorado pelas imensas formigas do Brasil central, sem que tivesse, depois de tantas decepções, modificado quaisquer dos seus desejos utópicos e tampouco a sua atuação no mundo.

Lídia e Otávio, ela, psicanalista, ele marxista, representam as duas pontas a serem unidas para a formulação da busca de Nando: a busca da verdade

\footnotetext{
${ }^{1}$ Idem, Ibidem.
} 
pessoal associada à revolução social. Porém, eles não conseguem amoldas as visões d emundo num único caminho, como tentará fazer o protagonista, mantendo muito mais uma preocupação com as frustrações pessoais do que com os problemas sociais.

Rolando Vilar é o ideal de homem de Otávio, que o vê omo um sucessor de Carlos Prestes pela firmeza de espírito e determinação. Segundo Otávio, só um homem como Vilar poderia fazer com que os brasileiros virassem os olhos para 'dentro do Brasil' e se revoltassem contra a exclusão social e a miséria. Contudo, o ideal de Vilar não é promover uma revolução social, seu desejo é promover obras, construindo estradas aeroportos, escolas e afim de ligar o interior às grandes capitais e de fornecer infraestrutura à população. Vilar cultiva em sua perspectiva utópica a modernização do país, pois crê que só a tecnologia pode ajudar a salvar o Brasil:

“-Existem trabalhos centrais, vitais - Disse Otávio.

- A Revolução - suspirou Vilar sabendo o que vinha.

- Claro que a Revolução e ela só poderia ser desfechada por um homem como você, Vilar.

- Você sabe que eu acredito em estradas - disse Vilar.

- Mas estradas para quê? - disse Otávio. - Isto é que você deve perguntar a você mesmo.

- Ué - disse Vilar - para os brasileiros andarem.

Para se conhecerem.” ( p. 188 )

A impossibilidade de se construir um projeto de nação viável é consequência da falta de identidade nacional e da marginalização do interior 
brasileiro em relação às grandes capitais, o que gera um profundo sentimento de desequilíbrio e incompreensão e, consequentemente, a desintegração da utopia coletiva em utopias pessoais. Cada personagem guarda um imaginário utópico, que reforça a sua personalidade e a sua visão particular de mundo, fixando os limites entre o 'eu' e o 'outro'. Esses limites tomam-se intransponíveis, já que os homens, individualmente, não possuem ainda uma consciência política suficientemente amadurecida para recomporem os fragmentos num único todo, numa única utopia coletiva.

O protagonista, no Xingu, começa a reconhecer a briga voraz entre os egos dos companheiros e, incomodado, esforça-se por buscar a integração das várias visões de mundo. O índio cumpre papel fundamental nessa busca uma vez que é um dos elementos que mais contribui para a formação da sua consciência histórica. Ao reconhecer a dor e o sofrimento dos indígenas, Nando entende que os preconceitos que tinha a respeito desse povo não correspondiam em nada à realidade.

Como vimos, as suas primeiras frustrações dão-se logo que chega ao Xingu, mas o verdadeiro reconhecimento de que os índios sofrem com a presença do homem branco - assim como, paralelo que Nando fará mais tarde, a população sofre com a opressão das elites sócio-econômicas - ocorre quando Lídia leva-o para conhecer Aicá, um dos indígenas que adquirira fogo selvagem. A imagem de Aicá absolutamente isolado e cheio de terríveis sofrimentos, causa em Nando horror, pois o padre reconhece que aquele homem não sofre apenas pela dor física, sofre também pela dor moral de não ser aceito em sua comunidade, de estar fadado a nunca poder casar-se, nem ter filhos, nem trabalhar como os outros da sua tribo. 
A apatia dos indígenas revela-se em seu cotidiano. Desanimados e desaculturados, não querem trabalhar para a realização da festa ritualística de maior importância no Xingu, o quarup, celebração que faz com que os mortos revivam entre os vivos. A despeito da comunhão com a natureza, o índio mostra-se indefeso diante da tecnologia trazida pelo homem branco, o que leva Vilar a detonar dinamites dentro do rio Tuatuari, para garantir fartura no quarup. Se antes as tribos conseguiam através de seus próprios recursos promoverem seus rituais, agora mostram-se absolutamente dependentes da civilização.

Fontoura procura motivar os indígenas a festejarem o quarup, para impressionar Getúlio Vargas, que prometera visitar o Posto, e pela obrigação que sente ter de reintegrar o indígena a sua própria cultura, ensinando-os, como observa Otávio, 'a se manterem selvagens'. O quarup adquire, portanto, um significado muito maior para o homem branco do que para o próprio índio, assim como a presença do indígena no romance é mais importante enquanto formadora da consciência histórica dos visitantes do que enquanto meio de resgatar e preservar a história desse povo.

Essa impossibilidade de os índios serem autônomos ( ou porque, massacrados pela cultura do homem branco, tenham perdido a identidade cultura; ou porque reneguem suas manifestações culturais, seduzidos pela facilidade com que a civilização lida com os problemas práticos do cotidiano) retrata o silencio a que esse povo foi submetido ao longo dos séculos e as dificuldades que têm em compreender a serem compreendidos pelos brancos.

Por um lado, há a subserviência do indígena ao branco, por outro, há a culpa, a piedade ou mesmo o desdém do branco em relação ao índio. Nesse 
contexto, brancos e índios não conseguem se integrar socialmente, reproduzindo as relação entre opressor e oprimido, o que aponta para a condição de marginalização e descaso em que se encontra o interior do Brasil:

“-Meu Ministério ainda fala mal das derrubadas e queimadas, do nomadismo do homem do interior e não sei mais o quê - disse Ramiro. - Oficialmente pode estar tudo certo, mas como é que aguenta um abacaxi desses podendo morar no Cacete? Olhe, eu não vou dizer isso não, hem, que não sou doido. Mas a Constituição de 1946 garante o direito de ir e vir e eu considero um crime todos os artifícios usados para acabar com o êxodo rural. A Serra do Mar foi a barreira natural colocada por Deus para mostrar aos brasileiros onde deviam viver. Acho muito compreensível que os bandeirantes tenham invadido esse mundão do interior em busca de ouro. Mas, depois, fim. Devíamos fechar todo o interior do país. Nós somos o Chile do Atlântico.” ( p. 191 )

O protagonista participa ativamente de todos os acontecimentos e observaos com muita atenção. Como não é dado ao leitor conhecer seus pensamentos, em alguns diálogos e atitudes registra suas mais recentes opiniões sobre os índios, as quais sugerem as profundas transformações que sua visão de mundo vinha sofrendo. Tornando seu discurso solidário à voz antes solitária de Fontoura, é por oposição aos demais personagens que o aprendizado de Nando adquire formas mais precisas, o que vem a traduzir a 
sua preocupação em encontrar uma atuação coerente junto à trágica história do Brasil.

Todos os personagens apresentados no capítulo anterior, 'O Éter', integram esse terceiro capítulo, a fim de participarem da festa do quarup, seja por autopromoção, para fugir da crise política nacional, ou mesmo para resolver problemas passionais. A elite carioca desloca-se para o interior de Brasil, mas, ao invés de valorizar esse espaço, intensifica a posição periférica do Xingu em relação ao resto do país e desmitifica a figura de políticos e jornalistas, os quais, mesmo diante de fatos como a morte de Getúlio Vargas, que ocorre no último dia do quarup, preocupam-se tão somente com seus conflitos pessoais. O desenvolvimento da narrativa, nesse capítulo e no próximo, fixa uma estrutura que confere ao romance, ao mesmo tem, um tom trágico e irônico.

Sônia, a dançarina de casas noturnas, ocupa, contra a sua vontade, um papel central nos episódios que sucedem a chegada do Ministro Gouveia. O enredo, seguindo uma construção digressiva e a-linear, traz à tona as causas e consequências da paixão obsessiva de Ramiro, de Falua e do próprio Ministro por essa mulher. Mesmo sabendo das proibições em relação ao envolvimento sexual entra brancos e indígenas, Sônia foge com Anta, índio visto como despreocupado, um 'gigolô das selvas'.

A ousadia de Sônia ao abandonar toda sua vida na capital para viver com Anta provoca a ira em Ramiro e Falua e contraria os conceitos de Fontoura sobre a impossibilidade de índios e brancos integrarem-se. Sônia e Anta, como aponta Édison José da Costa', 'adentram juntos - a mulher sonhadora e o índio americano, Ceci e Peri revisitados - o terreno do mito'. A mata, em

\footnotetext{
${ }^{1}$ COSTA, Édison José da. Quarup: tronco e narrative. Curitiba, Scientia et labor, 1988. (p.88)
} 
meio às crises políticas, é o refúgio para o despojamento e a libertação e é o espaço ritualístico em que se traça um novo projeto histórico.

Concomitantemente a esse fato, ocorrem o quarup e a mudança de governo com a morte de Vargas. Numa explosão de cenas que se sobrepõem, desenha-se o destino arrevesado do Brasil e a impossibilidade de se construir uma nação segundo as diversas e divergentes utopias, sempre abortadas por algum inesperado fato histórico conduzido pelas elites nacionais:

“(...)Falua que acionava o Johnson na popa berrava para a margem à sua direita, Ramiro com desconsolada carranca à proa berrava seu Sônia pra a beira oposta e até índio já cansado do quarup berrava Sônia também só de picardia e divertimento. Otávio teve um ataque de fúria quando mais uma vez chegou diante do Posto o barco dos dois que berravam Sônia.

- Escapistas! Subdesenvolvidos! Caçando a mulher no mato com gasolina do Goverto enquanto o Goverto é derrubado!

- Vou levar os índios para o Rio - disse Fontoura bêbado, chegando da casa.

- Você é outro escapista - disse Otávio. - Protegendo índio!

Que topete. O Brasil inteiro é um Protetorado.” (p. 255)

A falta de valores gera uma profunda crise em relação ao respeito pelo outro e, nesse contexto, a história reduz-se à luta pelo poder. A imagem do país do Carnaval, sustentada pelos amigos de Ramiro, ou do Paraíso terrestre, segundo Nando, ou mesmo a imagem do governo do Pobres, 
como queria Vargas, são desmontadas diante da degradação das relações sociais e políticas.

A ironização dos imaginários dos personagens estende-se à da própria visão história do Brasil, uma vez que a narrativa, desqualificando a elite política e intelectual brasileira e as suas perspectivas utópicas, esvazia as visões dos brasis que se multiplicam de acordo com os projetos pessoais de vida. Exemplo disso é Ramiro, que crê que só através da proliferação das doenças o país poderia desenvolver-se porque o sofrimento faria com que os brasileiros valorizassem suas vidas e, portanto, a sua terra. Ramiro refere-se aos problemas do país como se fossem meras abstrações para divertir sua mente hipocondríaca. Muito mais preocupado como desprezo de Sônia por ele do que com os últimos acontecimentos históricos, o diretor do Serviço de Proteção aos Índios guarda verdadeiro asco do Xingu e dos próprios índios, ignorando o passado e o presente do Brasil.

Em oposição à intelectualidade que se mantém passiva em relação aos fatos nacionais, Fontoura, inspirado em Orlando Villas Boas ${ }^{1}$ e no Marechal Rondon, por causa da impossibilidade de chamar a atenção para o crime nacional contra os indígenas, orna-se um bêbado e busca a morte, depois de tanta frustração e desespero diante do cenário de destruição das culturas nacionais.

O quarup uialapiti recompõe o tempo mítico da criação e da vida, reintroduzindo, no espaço ritualístico, o antepassado morto no seio da comunidade. A morte aparece como o ato de preservação e revigoramento

\footnotetext{
${ }^{1}$ LEITE, Lígia Chiappini Moraes. "Entrevista com Antônio Callado”. In: O nacional e o popular na cultura brasileira. Artes Plásticas e Literatura. São Paulo, Brasiliense, 1982. Antônio Callado aponta para a associação de ambas as personalidades. Villas Boas e Rondon, na construção do personagem Fontoura, que vem representar o homem apaixonado pelo interior do Brasil e pelos indígenas.
} 
vital e o quarup compõe-se, para Nando, como o compromisso do ser coletivo com a história individual.

Porém, o desânimo dos índios para a preparação do quarup, causado pelas doenças disseminadas pelo homem branco e pela imposição da sua cultura e tecnologia, e o posterior cancelamento da visita presidencial, consequência das turbulentas políticas brasileiras interceptam o quarup, que representa a energia vital dos índios, e rompem com a unidade vida/morte buscada por um povo que sabe estar distanciando-se da sua tradição, da sua identidade, da possibilidade de perpetuar a sua existência no mundo dominado pelo homem branco. A ideia de fim contamina a vida dos índios e mostra o destino trágico a que essa população está condenada.

A morte gradativa dos índios plasma o 'apodrecimento' do país dentro dos próprios brasileiros. Ocorre não só a anulação da cultura indígena, mas todo o imaginário que ela gerou, extinguindo a visão romântica e nacionalista do Brasil. Estraçalhado o passado do país, rompe-se a possibilidade de projetarse o futuro e de, portanto, recriar-se o presente. É essa consciência que leva Fontoura a aceitar e acelerar sua trágica morte e é, por outro lado, essa mesma consciência, embora por objetivos distintos, que leva o grupo expedicionário a buscar o centro geográfico do país.

"A orquídea" é o quarto capítulo do romance, central, tanto no que diz respeito a número de capítulo e de páginas, quanto à importância que guarda em relação ao desenvolvimento da narrativa. Logo nas primeiras páginas denuncia-se o abandono em que o Posto da Funai, estabelecido no centro da aldeia indígena, encontra-se e a degradação moral de Fontoura sete anos depois do último quarup. O tempo desenvolve sua ação corrosiva, 
deteriorando o interior do Brasil por causa da absoluta indiferença do resto do país com relação a esse espaço. O homem branco renega os indígenas e as políticas públicas lançam-nos, junto a Fontoura e Nando, para a margem da História, para o total isolamento.

A sensação de vazio é reforçada pela desagregação do mosteiro, do Xingu, do passado e do presente do Brasil. A narrativa retoma o curso segundo os pensamentos e sensações de Nando, que volta a filtrar os acontecimentos. O narrados exime-se da função de organizar os fatos, deixando o romance seguir o turbilhão mental do protagonista. Tudo converge para a figura de Nando que ainda se mostra assustado com a sua própria decisão de ter rompido com o passado, com a Igreja, com a batina, com os interesses da civilização.

Para Nando, porém, o tempo é de amadurecimento, de decisões e de definições, uma vez que sua perspectiva utópica fora destruída pela mudança do seu olhar sobre o mundo, pautado, agora, em um horizonte religioso que tem no sofrimento e na disposição causal das circunstâncias a manifestação da vontade de Deus. É a partir dessa perspectiva que Nando irá desenvolver um projeto para o que ele julga ser a salvação do homem.

Em meio às imagens que se confundem na consciência do protagonista, vem à tona a cena em que Hosana, padre do mosteiro a que pertencia, mostra-lhe uma arma e expressa o intenso desejo de matar o superior, D. Anselmo, caso esse não o deixasse continuar o namoro com a Prima. Hosana concretiza seu anseio, assassina D. Anselmo e foge com a prima, despertando em Nando a culpa por não ter evitado o crime, já que ele lhe havia confessado anteriormente seus planos. 
O revólver, além de provocar a sensação de culpa no ex-padre, reintroduz em seu universo, e no romance, a imagem de Levindo morto, lutando pelas causas dos camponeses. O padre Hosana e o comunista Levindo tentam reverter situações opressoras através da radicalização dos atos de violência, flagrando a impossibilidade de se conviver pacificamente em uma realidade que há muito abortou os ideais de justiça e igualdade.

A violência penetra na vida do protagonista enquanto viabilização de um caminho para a transformação das relações sociais. Nando muito reluta à aceitação dessa ideia, mas pouco a pouco, vai a seu encontro, tendo como modelo de comportamento a figura do mártir, pois, como Jesus Cristo, ou como Levindo, dedicaria toda a sua história de vida ao outro, sofrendo passivamente os piores tormentos e buscando a morte para sustentar suas opiniões:

\footnotetext{
"Ele ao chegar à cela se considerava quase indiciado, criminoso, a velha ideia de martírio servindo de pano de fundo. De qualquer forma o cárcere de Hosana acabava por ser desejável em comparação com o cárcere ilimitado, a pena obscura." ( p. 268 )
}

Tendo conseguido que Ramiro lhe arrumasse um emprego no Serviço de Proteção ao Índio, Nando mora com Fontoura no Xingu e pacifica tribos indígenas dentre elas a reclusa e violenta aldeia dos txikão. O seu afastamento da Igreja abre espaço para que ele persiga, de maneira obstinada, a ideia de aprender a 'amar lentamente as mulheres' e de, inspirando-se em Fontoura, salvar os índios do furor expansionista do homem branco. 
Não mais acreditando nos resultados da caridade cristã, a presença de Nando no Xingu perde o caráter utópico que o levara a chegar até lá, ainda que suas duas últimas ações enquanto sertanista - a pacificação dos txikão e aproximação física de Aicá, índio portador do incurável 'fogo selvagem' sejam descritas a partir de uma ambientação impregnada de signos religiosos. Nando entende que o trabalho que realizava junto aos índios pouco utilidade tinha a eles, quando Aicá nega o carinho do ex-padre mal compreendendo o que ele queria:

\footnotetext{
"Em seguida estirou-se na rede ao lado de Aicá e o estreitou contra si, peito nu em peito nu, face direita contra face direita, seus lábios apertados contra o pescoço rugoso de Aicá. Assim ficaram os dois um minuto, imóveis, Nando sentindo bater de encontro ao peito o coração de Aicá. Finalmente Aicá sorriu vago e se desvencilhou de Nando, sentando-se na rede, tirante. Nando se levantou, apanhou a camisa e saiu ligeiro como um ladrão.” (p. 275)
}

É nesse momento que o protagonista rompe definitivamente com sua utopia religiosa, pois compreende os equívocos de suas ações, uma vez que conscientiza-se do fato de que a integração desejada entre brancos e índios torna-se absolutamente fora de propósito depois desses últimos terem sofrido um intenso massacre cultura.

A partir de então, Nando dá fim ao modo de vida sertanista, abandonando o isolamento em que se encontrava, para dedicar-se exclusivamente a sua paixão - de início platônica - por Francisca, que chega ao Xingu ao fim de 
cumprir a promessa feita a Levindo de fincar bandeira no Centro do Brasil e de levar/trazer terra de lá para os Sindicato dos Palmares.

Nesse ponto, a narrativa distancia-se do narrador onisciente, que passa a ser, predominantemente, observador, ocultado do leitor, mais uma vez, grande parte das emoções e dos pensamentos do protagonista. $\mathrm{O}$ romance vem a privilegiar nessa segunda parte o desenvolvimento da expedição ao Centro Geográfico, que conta com Ramiro e Olavo, já apresentados nos capítulos anteriores, Fontoura e seu futuro substituto no Posto - já que o Serviço de Proteção ao Índio via ser fundamental seu afastamento da Funai Vilaverde Lauro, um etnólogo, além de Francisca e Nando. Embora cada personagem veja a expedição como a possiblidade de realizar uma sua utopia pessoal, a viagem ao centro do país é a alegoria da necessidade coletiva de descobrir um Brasil desconhecido, imprevisível. O Centro Geográfico é o coração do país e, conhecê-lo, é descobrir os significados da nação, é forjar uma identidade nacional:

“-Pois eu estou na Expedição devido ao entusiasmo de

Levindo e...

Francisca apontou para Nando.

- Sim? - disse Nando.

- E devido ao seu desinteresse

- Meu desinteresse?

- Nas discussões com Leslie você não dizia que era o cúmulo a gente continuar fazendo pátrias no mundo de hoje?

-Bem, isto sim, me lembro. Mas..

- Pois você então não acha incrível que ainda exista um país em busca do seu coração?" 
A expedição adquire, de início, um tom heróico, mantido pela figura de Lauro - que entende a viagem como um fato inédito e de inigualável importância para os brasileiros, uma vez que nunca, ninguém, nenhum estrangeiro, chegou lá - e por Vilaverde - que propões um método de pacificação em que ao invés de os índios irem, por causa dos presentes, em busca dos brancos, esses é que se encaminhariam para o meio daqueles, deixando-se ficar à mercê das suas reações. Lembrando uma espécie de Rondon dos novos tempos, a bravura de Vilaverde reforça a imagem do sertanista ousado e agressivo inaugurada por Vilar, e encontra um reflexo em Nando, também por sua determinação e coragem ao pacificar os índios.

Porém, a cuidadosa construção do caráter heróico da expedição funciona na medida mesma em que se intensificam os trágicos acontecimentos que se sucedem até a chegada ao Centro. Contrariando todas as expectativas do grupo, logo que se veem verdadeiramente em perigo, Otávio e Lauro, que na verdade desprezam os índios, tentam atirar nos txucarramãe, porque esses, vivendo em condições miseráveis, fogem com a comida da expedição. Doentes e famintos, os índios lutam pela sobrevivência e as suas ações, como as dos brancos, não têm nada de heróicas.

A viagem ao coração do Brasil divide-se, dessa maneira, em duas partes: a primeira, paradisíaca, em que os brancos entendiam-se entre si e com os índios, em que a natureza era generosa e representava o reencontro com as forças divinas; e a segunda, que é o exato contrário dessa, é a descida aos infernos. Quanto mais avança a expedição, aprofundando-se no interior, mais intensas são as dificuldades e a viagem transforma-se num caminho de provação e suplícios. 
A Ruptura com o equilíbrio inicial dá-se em paralelo com outra ruptura fundamental na vida de Nando: ele, finalmente, tem uma relação sexual com Francisca, na qual encontra um prazer nunca dantes experimentado. A satisfação de Nando ao conseguir superar sua ejaculação precoce confere um romantismo ainda maior ao episódio, que se desenvolve numa maravilhosa vereda de orquídeas e num equilíbrio quase perfeito entre intenções e gestos, vindo a recuperar, como nos alerta Lígia Chiappini, a representação de um tempo mítico:

“A planta ( orchidion, do grego = testículo) símbolo da fertilidade, aparece no centro da floresta tropical, com muita água e muita cor, no momento do encontro de Nando e Francisca, e no centro do livro. É quando o herói, fundindo numa só a Francisca real com a Francisca da sua imaginação, deixa de ser impotente para encontrar-se na sua masculinidade, encontrando o seu complemento feminino. A integração dos amantes com a natureza é completa, a mulher se funde com as flores e a cena reatualiza o mito de Adão e Eva, inocentes a descobrir o amor no paraíso."

Mas essa integração natureza-amor logo se rompe com a culpa sentida por Francisca, pois ela crê que, amando outro homem, estaria traindo Levindo. Essa culpa faz com que a sua relação com Nando adquira um sentido negativo na narrativa, antecipando o tom trágico que, a partir daí, a viagem terá: a enxaqueca de Ramiro, o encontro com os txucarramãe, as bolhas nos pés de Francisca e a doença de Fontoura. Depois disso, no último círculo do inferno, o encontro com os cren-acárore, e, no centro dele, o imenso sauval.

\footnotetext{
${ }^{1}$ LEITE, Lígia Chiappini. Op. Cit. (p.165)
} 
A ironização dos propósitos heróicos da expedição contamina a própria mãe natureza e a pátria gentil. As saúvas impedem que a Vilaverde coloque, além do padrão, um mastro para ali fixar o emblema nacional. O grupo, já cansado e faminto, frustra-se ainda mais com o formigueiro ameaçador, que acaba de matar Fontoura, já muito doente:

“- Vamos voltar, Fontoura;

- Espere, espere.

Quando chegaram ao pé do padrão fontoura pôs os joelhos no chão e leu:

- Centro Geográfico do Brasil, latitude dez graus e vinte minutos sul, longitude cinquenta e três graus e doze minutos oeste de Greenwuich.

Fontoura se levantou, mais pesado, muito mais pesado do que antes. Francisca esfregou a cara e o pescoço de Fontoura negros de saúvas, passou a mão no próprio rosto, arrastou Fontoura para fora do formigueiro que agora fervia como um fogo negro-fulvo de cabeças e ferrões.” (p.p. 376 e 377)

A elaboração narrativa de Quarup não ironiza apenas o imaginário coletivo u os imaginários individuais - representados pelos personagens - a respeito da identidade nacional, mas a própria estruturação do livro, que, a cada transformação anunciada na intimidade de Nando, renova-se ( ou mudando o foco narrativo, ou o ritmo de texto, ou o enfoque predominante ), como se o romance negasse as soluções encontradas anteriormente tanto pelo 
protagonista como pelo autor. Neste momento da narrativa, o romance imerge em um ritmo intenso em que se cruzam as ações e pensamentos dos personagens, os quais convergem para uma única avaliação trágica da realidade.

O tom heróico buscado no início da viagem é desmontado devido à impossibilidade de se construir um mundo épico. Isso se dá, segundo Lukács ${ }^{1}$, depois da chamada era moderna, uma vez que ao homem deixa de ser possível aprender a totalidade do mundo, o sentido da vida, passando a agir de maneira equivocada:

"O romance é a epopeia de um mundo sem deuses: a psicologia do herói romanesco é demoníaca, a objetividade do romance, a viril e madura constatação de que nunca o sentido poderia penetrar de lado a lado a realidade e que portanto, sem ele, esta sucumbiria ao nada e à inessencialidade."

Antônio Callado compõe um romance que ironiza ${ }^{2}$, ao mesmo tempo, a própria tentativa de retomar o caráter heróico das composições épicas e a expectativa do leitor com relação à inteireza dos personagens e às imagens do Brasil cultivadas ao longo dos governos populistas. Os personagens estão

\footnotetext{
${ }^{1}$ Op. cit. (p. p. 95-106)

${ }^{2}$ Beth Brait tem u m estudo bastante rico e esclarecedor sobre a ironia enquanto elemento estruturador do enunciado e sobre a sua função no discurso: "Constituindo um fenômeno bivocal, dialógico, um sistema de interação, para utilizar os termos de Bakunin, as formas de recuperação do já-dito com o objetivo irônico não assumem, como tal, a função de erudição, no sentido de invocação de autoridade e muito menos de simples ornamento. Ao contrário, são formas de contestação da autoridade, de subversão de valores estabelecidos que pela interdiscursividade instauram e qualificam o sujeito da enunciação, ao mesmo tempo em que desqualificam determinados elementos.” In: Brait, Beth. A ironia em perspectiva polifônica. Campinas. Editora da UNICAMP, 1996. (p.107)
} 
sempre prontos para fugir da difícil luta de construir o Brasil: Francisca vive o dilema de quem aprendeu que só às custas de muito desassossego e dor o país pode ser libertado e recriado e sente-se tentada a fugir para um universo burguês, pleno de comodidades e tranquilidade; Otávio mantém-se sempre longe dos conflitos, exercitando muito mais sua oratória do que defendendo de fato suas ideias; Fontoura prefere a embriaguez e a morte; e Nando renuncia ao mundo para seguir os passos de Francisca. Assim também o Brasil parece não reconhecer os filhos pródigos, sempre os decepcionando, gerando e fazendo multiplicarem-se os traidores da pátria.

Ao final do capítulo, chega o hidroplano para salvar o grupo, depois muitos dias sem aparecer nos céus do Xingu. O piloto Amaral, responsável por assessorar a expedição, só consegue ir ao centro geográfico com a ajuda da Missão Militar Americana, sendo, por isso, acompanhado por um americano, Major Norry. É só nesse momento que os expedicionário descobrem os motivos do atraso da ajuda solicitada: a renúncia de Jânio Quadros, apenas sete meses depois de começado o seu mandato.

Esse último capítulo encerra-se da mesma maneira que o anterior, 'A maçã', encerrara-se, definindo a absoluta marginalização do interior do Brasil. Primeiro, a morte de Getúlio Vargas, pondo fím à esperança de Fontoura de proporcionar ao indígenas condições para que eles sobrevivessem à exploração dos brancos; depois, a renúncia de Jânio Quadros, que faz com que os expedicionários, cujos intuitos eram a integração ao Brasil do interior e a construção de um projeto de nação, sejam abandonador no meio da silva, pondo suas vidas em risco.

A história arrevesada do Brasil surge como a responsável pelo esfacelamento das utopias, sejam elas pessoais ou sociais, as quais não 
sobrevivem, como os índios não sobreviveram, às profundas crises nacionais. O suplício dos expedicionários, junto aos cren-acárore que lhes perseguiram para terem o que comer, acaba no vazio, embora tenham conseguido chegar ao centro e aí fincar o padrão. O mastro, colocado com muito cuidado por causa do sauval, lá ficou sem, contudo, a bandeira do Brasil, já que haviam esquecido no Posto. A todos esses fracassos soma-se a presença do americano e a maneira debochada com que trata o grupo de brasileiros, afirmando a superioridade de sua civilização.

Os personagens encontram-se ao final da viagem, longe de suas antigas convicções, e o que seria um contato com um mundo edênico, nada mais é do que a aproximação com uma população marginalizada e oprimida, com uma parte do Brasil rejeitada. Índios e brancos não conseguem encontrar o verdadeiro eixo das suas identidades, o que os faz perder de vista o centro dos mundos geográfico e humano e os contornos das utopias.

Da construção de um quadro de miséria e abandono, destaca-se a violência do homem nas relações entre opressor e oprimido, que se desenvolver num intenso confronto, seja no caso dos indígenas, seja no caso de Getúlio Vargas, seja no caso de Levindo ou de Fontoura. Em todas as situações, os homens mataram ou morreram, direta ou indiretamente, por força de suas utopias, pessoas ou coletivas.

Cada história de vida caracteriza as opções e os anseios de cada personagem. Os diversos perfis construídos ao longo do romance representam perfis mais gerais dos grupos sociais a que pertencem. $\mathrm{O}$ conjunto deles desenha a variedade de projetos utópicos - muitos dos quais somente visavam a conquista de uma felicidade individual, outros a salvação dos indígenas, outros a emancipação dos camponeses, outros a construção 
de estradas - e aponta para o conflito da esquerda da época que se enfraquecia pela impossibilidade de apresentar um projeto político, econômico e social que contemplasse as diferentes, e por vezes incompatíveis, visões do Brasil. Essas diferentes visões preveem diferentes caminhos para a nação, os quais, para serem conquistados, oscilavam entre a escolha da luta armada ou da luta pacífica, via cargos políticos, via conscientização das massas. ${ }^{1}$

Nando dialoga com essa realidade social que se encontra impregnada de violência e intolerâncias, definida pelas tensões de uma sociedade que tem de viver o confronto entre forças opostas de renovação e conservadorismo, entre o desejo de libertação do homem das antigas relações de poder e o da manutenção de valores e privilégios próprios às estruturas arcaizantes e injustas. Em 'A Orquídea', vida e morte estão tão próximas que o grotesco da expedição em busca da identidade nacional, metaforicamente traduzida na busca do coração do Brasil, revela-se num trágico equívoco, provocando em Nando uma profunda desconfiança das possibilidades de transformação social.

Não à toa o protagonista torna-se um seguidor de Francisca, pois que a sua paixão por ela não se revela apenas na relação platônica ou na plenitude do gozo sexual, mas, fundamentalmente, nos caminhos apontados por ela, sombra viva do noivo Levindo:

\footnotetext{
1 "Discutia-se um modelo de revolução, e como se chegar a ela. Pelo menos duas concepções se chocavam. Uma entendia a revolução como ruptura violenta, isto é, como uma explosão desencadeada por uma vanguarda que, ao ser logo substituída pela classe operária, criaria uma sociedade nova e um homem novo. Defendiam essa concepção as organizações que já se preparavam para a luta armada e os setores estudantis e culturais a elas ligados. A outra posição, defendida pelo PCB, via a revolução não como um objetivo imediato, e sim como um lento processo que poderia até culminar com uma ruptura, desde que fosse o resultado da gradual organização da sociedade civil e da acumulação de forçar" In: Ventura, Zuenir. 1968. O ano que não terminou. Rio de Janeiro. Nova Fronteira, 1988. (p.62)
} 
"Nando olhava Francisca que ia e vinha entre as barbudas sombras dos caraibas ou entre os índios esquálidos e evocava imagens de santas levadas em procissão pelos pestilentos de outras eras. Como podiam outras pessoas transformar impulsos como aquele que arrastava para Fran- cisca em alguma outra coisa que não fosse o próprio im- pulso" (p.p 366 e 367)

É por Francisca que Nando toma a decisão de engajar-se nos trabalhos sociais junto ao campesinato. Desejando ficar junto dela e seguir-lhe os passos, o protagonista volta a Pernambuco disposto a assumir qualquer tipo de atividade, desde que pudesse alimentar seu amor platônico e possibilitar uma atividade social. Mais uma vez, com o 'O ossuário', são as motivação pessoais do ex-padre que o conduzem a um trabalho que visa à transformação da realidade, sugerindo a íntima relação entre Amor e Revolução.

Francisca concretiza o papel revolucionário da mulher, porque acaba por representar a força renovadora que luta pela transformação das relações sociais fortemente marcadas pelas características típicas do universo masculino: poder, violência e intolerância. Até partir definitivamente para a Europa, Francisca dedica-se às causas populares e faz de sua vida uma luta pacífica pelas causas sociais. Embora tenha sido o próprio Levindo o maior responsável pelo engajamento social de Francisca, ela nega o modo de luta do ex-noivo, que se fixava na necessidade de se fazer o confronto armado com o opressor. O caminho de Francisca é o de doar trabalho e amor e é por esse amor que Nando não hesita em engajar-se na luta pacífica revolucionária. 
A realização sexual de Nando e de Francisca restabelece, no contexto geral desse capítulo, a harmonia entre a natureza e homem. Momento único e fugaz, abre uma fenda de vida num mundo de mortes. Concretiza-se num lapso de tempo a utopia de uma vida que proporciona ao homem a mais plena realização.

A utopia perseguida pela expedição marca o tom conservador e nacionalista do grupo, o qual espera ver ressurgir a imagem idílica de um Brasil, que, acredita-se existiu no passado: uma terra virgem, dotada de uma natureza generosa e habitada por índios selvagens, porém pacíficos e ingênuos.

Todavia, a viagem ao Centro Geográfico, antes tido como lugar sagrado, torna-se um lugar de força centrífuga, que arrasta as pessoas para longe de si, como o Brasil arrasta os marginalizados. Presos pelos cren-acárores até o final da expedição, um tom de ironia domina a composição das cenas, cujos contornos grotescos introduzem o estranhamento e a inquietação. A tribo, acometida de diarreia, evoca o estado doentio, de debilitação e desamparo em que se encontra o país. É como se a narrativa, mostrando o aprisionamento da expedição pelos índios, a filmagem da mata para recompor as aventuras de Sônia por uma equipe estrangeira, o incrível formigueiro no local exato do Centro Geográfico, mostrasse o drama nacional e desvendasse os frágeis alicerces sobre os quais se sustenta o mito da nacionalidade brasileira.

Minando o Centro, a viagem que se traduzia na busca da alma nacional, num mergulho fundo à procura de raíses que se alongassem na direção da construção de um mito, converte-se num contejo fúnebre. Para Nando, completa-se a descoberta do homem oprimido e de Francisca, do amor e da luta. 
O esfacelamento do imaginário utópico de Nando e a decisão de conquistar Francisca fazem-no partir com ela. A vida dos dois em Pernambuco extingue as utopias passadistas e inaugura uma nova perspectiva: a revolução pela palavra.

'A palavra', quinta parte do romance, funda, dessa maneira, os novos horizontes utópicos de Nando, que Nascem da observação da realidade e do longo aprendizado e amadurecimento adquiridos no convívio com a miséria dos índios. Nando compreende que, apesar da ameaça do terrível sauval no coração do país, conhecer aquilo que representa a alma nacional é fundamental para que sejam propostas as profundas mudanças a serem feitas no país.

Antônio Callado, com clara intenção de perseguir os movimentos da esquerda e da direita daquele momento histórico, procura traduzir, nas primeiras páginas desse capítulo, a atmosfera que a conduta de Arraes e de Jango e os últimos acontecimentos internacionais geraram no Brasil. Tomadas pela euforia das vitórias contra o capitalismo em Cuba e na Argélia, além da Revolução Cultural promovida na China e da guerra do Vietnã contra os Estados Unidos, as esquerdas produziram uma intensa campanha para a educação e politização das massas camponesas. ${ }^{1}$

Para tanto, a narrativa abandona o interior do Brazil e retorna aos pólos econômicos e políticos. O enredo desenvolve-se em Pernambuco, quando

\footnotetext{
1 “A influência internacional tinha outra fonte importantíssima nas lutas revolucionárias dos países de predominância camponesa. As vitórias das revoluções cubana e argelina, a guerra travada pelo Vietnã contra os Estados Unidos e a Revolução Cultural chinesa impressionaram tremendamente a juventude politizada dos anos 60. Daqueles eventos e do que sobre eles se escreveu ressaltava uma conclusão: a da potência revolucionária do campesinato.” In: Gorender, Jacob. Combate nas trevas. A esquerda brasileira: das ilusões perdidas à luta armada. São Paulo, Ática, 1990.
} 
Arraes é governador e João Goulart, presidente, num período em que as Ligas Camponesas atingiam o auge de sua movimentações políticas e educacionais ${ }^{1}$.

A cena inicial mostra Francisca desenvolvendo o Sistema Paulo Freire ${ }^{2}$ em uma aula de alfabetização, na qual são explorados os significados de palavras como 'classe', 'clamor', e 'reclamo'. Nando por sua vez, aparece deslumbrado com o aprendizado dos camponeses e com a dedicação de Francisca. Essa introdução mostra a aproximação dos dois personagens voluntários aos trabalhos da esquerda e a empatia que eles têm pela revolução pacífica e gradativa. Apesar de ambos oporem-se aos meios revolucionários defendidos por Levindo, a partir desse capítulo, a figura do guerrilheiro torna-se central no desenvolvimento de toda a narrativa, chegando mesmo a se tornar, depois de morto, o modelo exemplar para o protagonista.

A ação narrativa abandona o interior do Brasil e o protagonista distancia-se radicalmente das suas antigas preocupações, das atividades de valente sertanista, e passa a conceber o indígena como parte essencial da sua nova consciência política, negando a visão do Brasil idílico e pictórico. Suas experiências pregressas, no mosteiro e no Xingu, são substituídas pela vida de ativista de esquerda e sua visão de mundo alarga-se ao ponto de ele

\footnotetext{
${ }^{1}$ Sobre o tema, ler: Mendonça, Sônia Regina de e Fontes, Virgínia Maria.História do Brasil recente: 1964 - 1980. São Paulo, Ática, 1988. (Série Princípios, 152)

${ }^{2}$ Sistema Paulo Freire, concebido em Pernambuco, despertou um profundo debate a respeito da metodologia das escolas tradicionais, além de inaugurar uma nova consciência que se baseava na educação como um meio de garantir à população o pleno exercício da cidadania, o que significaria, em ultima instância, um caminho para a revolução social. Antônio Callado, em uma série de reportagens a respeito do governo de Miguel Arraes, entre o final de 1963 e o inicio de 1964, faz a seguinte observação: “Uma das palavras geradoras no Sistema Paulo Freire é a eleição. Uma das esperanças dos que usam o sistema é poder aumentar, já em 1965, o contingente eleitoral, isto é, tirar gente condenada ao limbro do Art. 132.” In: Callado, Antonio. Tempo de Arraes: a revolução sem violência. 2 ed, Rio de Janeiro, Paz e Terra. 1979. (p.p. 158-159)
} 
compreender a necessidade de se lançar à árdua tarefa de transformar a história:

\begin{abstract}
"Francisca útil, pensava Nando, como se em fogo santo se cozesse pão. Pão. Vida. Voto. Saúde. Depois das caras impassíveis do índios as caras dos caboclos que de repente viam no bloco de letras uma realidade transposta e quase berravam foice ao sol cegos por fio de foice e brilho de sol" (p.p. 385-386)
\end{abstract}

Nando explode, então, seu antigo referencial de mundo, antes limitado à Francisca. Torna-se professor e conselheiro, disseminando a sua admiração e entusiasmo pelo Governo de Arraes. A esperança de que a revolução ocorrerá de maneira pacífica e paulatina transforma a utopia do protagonista, que passa a projetar um mundo em que as classes oprimidas, através da educação e da consciência política, subverterão, democraticamente, a ordem estabelecida a fim de criar uma sociedade igualitária. ${ }^{1}$

A história recente do Brasil, quase abandonada em 'A Orquídea', é resgatada com todos os conflitos da esquerda em voga. E é pela ênfase dada à história nacional que o narrador denuncia a dissociação entre o mundo exterior e o universo subjetivo que persiste em Nando. Ainda que tenha tido um profundo aprendizado e que tenha adquirido uma consciência crítica a

\footnotetext{
${ }^{1} \mathrm{O}$ deslumbramento de Nando por Miguel Arraes pode ser melhor entendido se atentarmos para a imensa admiração do próprio escritor. Antônio Callado, pela conduta política do governador pernambucano: “A revolução de Pernambuco era 'piloto', no sentido de que provavelmente inspiraria a revolução maior, brasileira, e ambas tinham jeito de triunfar à brasileira, com bons modos e pouco sangue. Agora não sei. O que inconscientemente deseja talvez o regime do Ato Inconstitucional de 9 de abril de 1964 é contrariar a revolução do povo para ver a cara do Brasil desconhecido que há séculos borbulha por baixo da nossa preguiça de fazer História.” (Idem, ibidem. p.42)
} 
respeito da história nacional, Nando lida com os seus sonhos e com as suas expectativas como se esses fossem partes, efetivamente, da sua realidade.

A presença ausente de Francisca, fugidia às mãos de Nando e fiel à memória de Levindo, é exemplo desse seu mundo onírico: Nando acredita que se casará com Francisca e que com ela ficará para todo o sempre. Ele vê a salvação do homem na aprendizagem do verbo. Nando crê na Revolução que, segundo ele, Miquel Arraes promovia sem enxergar a forte oposição que o governo de Pernambuco sofria. E está certo do apoio de Jango à movimentação da esquerda:

“- Você não acredita? O Presidente da República é a favor de vocês...

- O Jânio - disse Manuel

- Jango - disse Nando.

- Ah, sim, é o outro

- E o Governador do Estado então nem se fala - disse Nan-

do - Este morre com vocês se for preciso.” (p. 405)

A cegueira de Nando diante da complexidade das relação de poder impedeo de perceber os obstáculos a serem vencidos. Crendo no sucesso do seu amor por Francisca e no sucesso da Revolução, o protagonista entra em conflito com o mundo sem perceber, esperando ver todas as suas utopias realizadas mesmo sem conseguir imaginar como isso ocorreria.

Tal conduta caracteriza, segundo Lukács, o 'idealismo abstrato', ‘porque uma vida que está em condições de obrigar a sair todos os conteúdos do seu próprio fundo pode estar cheia e acabada', o que impele o protagonista 'a um excesso de atividade, manifestada para o exterior e que nada podia 
travar' ${ }^{\prime}$. Nando só reconhece essa sua renovada 'cegueira' quando é preso e torturado junto a outros camponeses e quando Francisca parte, novamente, para a Europa, o que o leva a fazer um profundo exame de sociedade brasileira e de si mesmo.

Assim como a construção do protagonista tem como preocupação revelar sua atitude política, a dos outros personagens apresenta as diferentes correntes e grupos da esquerda nacional: Jorge Djamil, estudantes, desejam a luta armada; Otávio, do PC, defende um processo de transformação lenta, que evite o confronto com a direita; Januário, das Ligas Camponesas, radicaliza o discurso e trabalha pela revolução imediata, independentemente dos meio necessários para conquistá-la; há ainda, o Padre Gonçalo e Francisca ( além de Nando ), que atuam, primeiramente, a favor da politização das massas e da transformação da consciência nacional, para depois efetivar-se, como consequência direta, a verdadeira revolução.

$\mathrm{O}$ romance resgata a euforia das esquerdas em Pernambuco ${ }^{2}$, mas aponta bastante propício para o fortalecimento das utopias, as diferentes e mesmo antagônicas propostas para que elas se concretizassem dispersam o trabalho da esquerda, favorecendo as forças reacionárias. ${ }^{3}$

As fervorosas discussões e os intensos conflitos entre condutas políticas tornam-se mais acirradas na medida em que o governo começa a reprimir a

\footnotetext{
${ }^{1}$ Op. cit. (p.130)

${ }^{2}$ Mendonça, Sônia Regina e Fontes, Virgínia Maria. História do Brasil recente: 1964 - 1980. São Paulo. Ática, 1988.

${ }^{3}$ É comum na avaliação do período histórico que compreende as décadas de 60,70 e 80 críticas aos equívocos da esquerda com relação à sua conduta política ( ver Combate nas trevas, de Jacob Gorender. p.p. 55-69 ). Surpreende, porém, a perspectiva crítica apresentada por Antônio Callado em Quarup, uma vez que a narrativa referese a um passado recentíssimo e ao próprio presente, os quais, por causa da repressão e da falta de unidade entre as várias correntes de esquerda, tornavam quaisquer análises suscetíveis de terem sido elaboradas para favorecer um ou outro aspecto da realidade nacional, ou de não conseguirem, devido à posição do intelectual num contexto de ditadura militar, avançar na compreensão daquele momento histórico.
} 
oposição. Pouco antes do Golpe Militar, em 1964, embora as esquerdas nacionais estivesses muito divididas, todas, inspiradas nos últimos acontecimentos históricos, acretitavam na derrocada do capitalismo. Paradoxalmente, os únicos a questionarem o sucesso da sonhada revolução fazem parte dos mais oprimidos pelas elites econômicas e políticas. Diante das colocações de um homem do povo, Nando responde com inabalável convicção:

“- A coisa é a seguinte: A gente tem lá em Brasília o Jânio, quer dizer, o Jango, e tem aqui o nosso governador. Mas imagina que essa gente finória dona das terras enrola os dois.

- Agora não enrola não - disse Nando - fique tranqui1o"(p. 406)

As conflitantes posições políticas da esquerda flagram as deficiências dos homens que não conseguem chegar a uma maneira comum de enfrentar o terror, sobreviver a ele, para enfim, transformá-lo. A impossibilidade de conquistar uma unidade viável deve-se à ausência do sentimento de coletividade, uma vez que todos buscam realizar-se, antes de qualquer coisa, individualmente.

É preemente a necessidade que os homens t em de reencontrarem a si mesmos e recuperarem o sentido das suas vidas pessoais, superando os profundos sentimentos de solidão e de fracasso. Desencontrados dos seus eixos e deprimidos por não conseguirem vender suas frustrações, os homens não encontram possibilidades para suprimirem suas diferenças e abraçarem causas comuns. Disso decorre a interferência do plano individual do plano 
social e vice-versa: porque não compreendem o 'ossuário de naturezas mortas' em que se tornou o mundo, os projetos coletivos não se realizam e tormam os homens, pessoalmente, menos realizados isso faz com que ajam de maneira equivocada, o que leva, fatalmente ao fracasso dos projetos coletivos. ${ }^{1}$

Com tal funcionamenteo social, assistimos a uma disputa intensa dentro das esquerdas, que se revela no comportamente, muitas vezes incompreensível se se pensa nas ações terríveis da direita, de muitos dos personagens. Januário é exemplo dessa condição, bem como o é Nando. Ambos não tem lucidez para avaliar o que pensam e o que querem os camponeses e quais os caminhos viáveis para a revolução. Em meio a um surto de varíola em Pernambuco, como se não bastasse a fome e a opressão, Nando e Januário discutem por causa das doações de leite, comida e remédio enviadas ao Estado:

“Januário jogava agora punhados de ampolas no chão. Nando subiu num salto ao caminhão e pegou Januário pelos ombros -para com essa estupidez ou eu dou o alarma. Você não está doente e não está com fome. Esta violência te sai muito barata. Faz a tua revolução mas deixa que os que precisam aceitem a caridade alheia.

- Caridade só vale quando a gente dá as coisas que fazem falta à gen- te. Sai da minha frente.

Nando se atracou com Januário e sentiu uma dor aguda nas constas, no glúteo. Escorregou ao se afastar de Januário, rolou por cima de uma lata e caiu no chão branco de leite em pó.” (p. 427)

${ }^{1}$ LIKÁCS, Georg. Op. Cit. (p.p. 155-169) 
Como eles, Jorge e Djamil, o Padre Gonçado e o próprio Otávio debatemse por entre as contradições da esquerda e afastam cada vez mais o sonho de um pais diferente. Solitárias, as correntes da esquerda se enfraquecem ainda mais diante da enorme máquina, sólida, da repressão. As várias vozes vêm à tona, acompanhando os movimentos do protagonista, que se persegue, silenciosamente, os passos de Francisca, irredutível a seu amor.

É através da democratização do foco narrativo que tomamos conhecimento das desconfianças dos camponeses com relação à posição política de Nando, o que pontua o texto de índices do que irá ocorrer alguns anos depois com o decreto do Ato Institucional número 5.

O protagonista não consegue ter um olhar dialético sobre a realidade, pois, apesar de todo o processo de aprendizagem vivido por ele, ainda não conquistou uma revolução interior profunda que lhe desse condições de criar expectativas dentro das possibilidades oferecidas por seu contexto histórico. O processo de aprendizagem de Nando limitou-se, então, a destruir suas antigas perspectivas utópicas e a recriar outras sem, porém, avaliá-las. Crendo piamente na concretização da Revolução social, tranquila e paulatina, como queria Francisca, Nando reforça as primeiras impressões do inicio da narrativa: o fanatismo pela religião católica transforma-se na fé cega nos governos brasileiros.

Coloca-se o problema fundamental da narrativa que é a necessidade dos homens de fazerem a História nacional e, não, de deixá-la à deriva para servir às elites e a interesses escusos. Nando vê-se nessa cilada, uma vez que ele mesmo não sabe nem como direcionar sua vida pessoal - sempre aos pés de Francisca, que o rejeita para homenagear, de alguma maneira, Levindo - 
quanto mais a história nacional - crendo fielmente na força política de Arraes e Jango.

O imenso abismo entre ideia e ideal, entre o que é a realidade possível e os sonhos impossíveis, reforça o grotesco na composição do protagonista e no tom geral da narrativa, uma vez que o caráter demoníaco do herói ( Lukács ) é definido: ele vive sua realidade puramente interior, que "entra em concorrência com a do exterior, e que possui em si própria uma vida rica e movimentada, e se considera, na sua espontânea confiança em si mesma, como a única verdadeira realidade, como a própria essência do mundo, constituindo o seu fracasso na tentativa de tornar efetiva essa adequação, o objeto mesmo da narrativa."1:

“- Logo agora - disse Gonçalo - quando o Governador pro - mete resolver o problema do Auxiliadora apesar da terrível situação do país. Sabe que ele escreveu uma carta a todos os Governadores do Nordeste dizendo que vem ai um golpe mi- litar?

Tinha, Nando tinha ouvido falar, mas a notícia não entrava no contexto das coisas aceitáveis. A pequena área comum de mun- do limpo arado e semeado pelos homens como criatura maio- res do que elas mesma não podia ser assim envenenada a pon- to de levar cada um de novo à casca da sua própria pele" (p. 421)

O herói deixa de pertencer, portanto ao tipo lukácsiano que corresponderia ao 'idalismo abstrato', como ocorre nos quatro capítulos anteriores, para

\footnotetext{
${ }^{1}$ LUKÁCS, Georg. Op. Cit. (p. 129)
} 
identificar-se com o 'romantismo da desilusão'. A nova fase de Nando continua a apresentar uma inadaptação entre a alma e a realidade, mas, agora, essa inadaptação "decorre do fato de a alma ser mais ampla e mais vasta do que todos os destinos que a vida pode lhe oferecer".

A diferença que daí decorre está no fato de a discordância entre a interioridade e o mundo estar na construção de um ideal concreto, qualitativo e rico em conteúdo - e não de um ideal absolutamente abstrato - que concorre com a realidade. Portanto, se antes Nando desejava construir um novo império católico, no coração do Brasil, agora ele projeta, a partir do momento histórico presente, a consolidação, gradativa, de uma sociedade mais justa e igualitária.

Falta, porém, ao protagonista, encontrar os meios viáveis para conquistar sua utopia, e, quando isso ocorrer, configurar-se-á, ao final da narrativa, o 'romance da aprendizagem'. Só aí torna-se possível compreender as intenções de Antônio Callado, pois fica claro que as suas opções para a construção da narrativa vão ao encontro do desejo de elaborar um 'romance da aprendizagem', o que, como veremos, corresponde aos anseios da época e à própria visão que o autor tem da função intelectual.

Esse mundo ideal que o protagonista julga estar sendo construído fica em ruínas, quando ele vai preso e é terrivelmente torturado pela repressão junto a outros camponeses. ${ }^{1}$ A narrativa, nesse ponto, passa a ser conduzida pelo fluxo de consciência do protagonista, fundindo os tempos passados ao presente e ao futuro abortado.

\footnotetext{
${ }^{1}$ Os camponeses sofreram duramente com o governo ditatorial. Mesmo aqueles que mal sabiam o que ocorria no país foram submetidos às mais violentas sessões de tortura sem que a sociedade tomasse conhecimento. (Ver: EMILIANO, José e MIRANDA, Oldack. Lamarca: o capitão da guerrilha. 12 ed, São Paulo, Global, 1989).
} 
A sensação de fracasso e de inutilidade diante dos amigos violentados brutalmente diluí-se, quando, solto, tenta viajar para a Europa, a convite de Francisca. Porém, como está proibido de sair do país, todo o sofrimento de Nando torna-se um quase remorso, por ter perdido sua única oportunidade de ser feliz. $\mathrm{O}$ ex-padre deixa vir à tona os verdadeiros motivos que o fizeram estreitar suas relações com a esquerda e a lutar pelas causas populares:

“- (...)Mesmo depois de abandonar o sacerdócio o senhor con-
tinuou entre os índios. Por que resolver de repente dedicar-se
a uma atividade inteiramente nova, em Pernambuco?
Nando Pensou um instante, alegremente, no efeito que teria ali a
resposta verdadeira. Se dissesse 'Francisca, tenente, vim atrás de
Francisca. Quem, tenente, não viria atrás de Francisca"
(p. 455$)$

Perdido em si mesmo e longe do próprio centro, Nando fizera de Francisca o eixo de sua vida e a ela perseguira como se apenas a sua presença pudesse preencher de sentido o vazio da sua existência. Desde os tempos do Xingu, Francisca fora a responsável pelo destino de Nando, ainda que ele tivesse a consciência de que, assim como ela era o seu horizonte, Levindo era o horizonte dela, e de que, quisesse Nando ou não, ambos seguiam cegamente a utopia daquele que fora chamado de o 'amigo dos camponeses'. A influência determinante de Francisca e Levindo em Nando só é racionalizada por ele nesse capítulo, 'A palavra', quando perde ambos e, pior, vê seus sonhos deslizarem nos porões dos órgãos de repressão:

"Nando pensava de olhos abertos no que iria acontecer a Otávio, Januário, aos padres empenhados na luta e, principalmente, aos 
pobres camponeses das Ligas e Sindicatos, mas quando fechava os olhos a única pergunta e a única sensação eram atribuladas saudades de Francisca, o desejo enorme de saber o que é que estava acontecendo a ela entre as ruinas do mundo de Levindo. $\mathrm{O}$ mundo de Levindo era aceito por Nando como o mundo, um mundo inteiro, mas construído em torno do parque que era Francisca. Já se construira um mundo para rodear e justificar um jardim? Claro que sim. A história viva e quente da humanidade é exatamente a da per- da de um parque e da ânsia de reavê-lo". (p. 446)

Nando anseia, desesperadamente, por reaver o seu centro, Francisca, mas, impedido de fazê-lo, deixa-se ficar em sua casa da praia à espera de uma possível oportunidade, negando os pedidos insistentes de Padre Gonçalo, que tenta convencê-lo a partir com ele para o interior do Brasil e ajudar a organizar a luta armada contra a ditadura.

Se a presença de Francisca fez com que o mundo subjetivo do protagonista se fundisse ao mundo objetivo, a ausência dela acentua o embate entre sua interioridade e a realidade nacional. O protagonista quer adiar o Brasil de Levindo para conquistar a sonhada felicidade de uma vida estritamente privada, longe das contradições e conflitos da vida coletiva.

A perda de algo irrecuperável (“A história viva e quente da humanidade é exatamente a da perda de um parque e da ansia de reavê-lo"), base do romance moderno, segundo Lukács, torna-se o mote fundamental de toda a existência de Nando: perda dos projetos jesuíticos, perda do seu grande amor, fracasso na tentativa de uma revolução socialista. A ironia ${ }^{1}$ presentifica-se na inversão dos papéis de ator e receptor: não é o homem que

${ }^{1}$ Georg Lukács. Op. Cit. (p. 27-39) 
cria um novo mundo, mas o mundo que cria um novo homem. A dolorosa aprendizagem de Nando é a de que sua ação está condenada ao fracasso e de que o tempo de luta nada mais é do que o contínuo adiamento das utopias. $\mathrm{O}$ homem não detém mais o poder de transformação e de construção, mas deve se submeter a um tempo cujo o princípio, segundo Lukács, é um 'princípio de depravação':

\begin{abstract}
“A maior discordância entre a ideia e a realidade é o tempo, o fluxo do tempo como duração. A mais profunda, a mais humilhante impotência da subjetividade em dar as suas próprias provas manifesta-se menos pelo vão combate travado contra estruturas sociais privadas de idéias e contra os homens que as representam, do que no facto de ela estar sem força diante do curso inerte e contínuo da duração; de se encontrar lentamente mas incessantemente rechaçada dos pincaros para onde se tinha penosamente içado; de essa realidade imperceptível ao movimento invisível a despojar progressivamente de tudo o que possuía e lhe impor conteúdos estranhos contra a sua vontade"
\end{abstract}

O tempo de aprendizagem de Nando não the deu maturidade, bem com o tempo de politização e de educação das massas camponesas não lhes deu a liberdade sonhada e o fim dos rígidos mecanismos sociais de opressão. Com o golpe, o povo mais uma vez teve que se submeter àqueles que estavam habituados a conduzir a história nacional

O herói reconhece que o ideal de libertação nacional e popular, elemento condutor que dá unidade e sequência à ação ficcional de Quarup, não vingou e que, embora tenha envolvido-se no esforço pela emancipação do trabalhador rural, as diferenças de classe não foram eliminadas e o

\footnotetext{
${ }^{1}$ Idem, Ibidem (p.p. 140-141)
} 
camponês, recém tirado do pau-de-arara, não conquistou nenhum habeascorpus par protegê-lo

A palavra que se tornara o modo de resistência ao latifundiário e à exploração capitalista perde a conotação do meio de aproximação do centro - espaço sagrado de recomeço e reconstrução - do universo de Levindo e a edificação do mundo ideal pelo governo de Pernambuco desaba sobre o protagonista.

A desilusão do protagonista é tanto mais funda à medida que ele ainda mantém uma visão idealizadora da realidade. Vivendo a intensa expectativa da retomada do relacionamento amoroso com Francisca, o protagonista contrapõe o seu projeto de caráter privado à esfera social, coletiva, sinalizando sua felicidade no âmbito do seu universo pessoal.

Quando Nando recusa-se a acompanhar Gonçalo, fica clara a ascendência concedida ao microcosmo individual, entendendo que qualquer situação política significa 'coisa nenhuma sem o corpo de Francisca e o seu amor por ele'. Honesto consigo mesmo, Nando não consegue mentir e por isso tornase alvo fácil das duras críticas dos ex-companheiros da esquerda.

Do paraíso almejado, Nando inicia a descida aos infernos. O terror instaura-se através de Ibiratinga, o chefe de polícia que o vigiará com raiva e obstinação, e que irá representar a inversão dos símbolos religiosos:

“- Eu vou lhe dizer uma coisa, Nando, que hoje talvez lhe pareça ridícula. O senhor sabe que eu comungo todos os dias? Sabe que hoje já comunguei?

- E todos os dias - disse Nando - o senhor diz ao seu confessor que tortura gente no porão do Batalhão de Guardas?

- Digo. E sofro com isso. O senhor sofre? Com alguma coisa?" 
(p. 464)

Quando Nando sai da prisão, tudo o que reconhece eram as 'ruínas da civilização que durara um ano'. As lembranças de Nando são parte de uma memória fraturada pela violência, e as histórias pessoal e coletiva, que são feitas de lembranças e esquecimentos, se perdem na mais profunda escuridão. O tempo presente de Nando é um mero vaguear sem sentido pelo Estado de Pernambuco, tomado e vencido pelas forças reacionárias, e o futuro, um fantasma de todas as suas utopias.

A ação do sexto capítulo, 'A Praia', narra o reencontro de Nando com a vida, depois de ter decidido romper com o engajamento político de outrora, ao menos temporariamente. Abandona a política, mas não abandona os caminhos que o levaram a ela: os prazeres sexuais. Nando proporciona às mulheres momentos de amor intenso e, aos homens, o ensinamento de como o fazer, acreditando nos benefícios que ele traz para a vida de cada um. O amor carnal funde-se ao amor espiritual e o ex-padre cria uma maneira de concretizar, como queria antes do Golpe, a violência do amor, que, acreditava, provocaria no homem uma revolução interior e, consequentemente, pacifica e gradativamente, a revolução social.

Dessa maneira, o herói liberta-se de si mesmo e, inspirado pela memória de Levindo, doa-se e solidariza-se aos homens sofredores através de gestos próprios ao universo feminino ${ }^{1}$. Se antes a 'palavra' guardava para o herói

\footnotetext{
1 "Para Jung, o feminino personifica um aspecto do inconsciente denominado anima. A anima é a personificação de todas as tendências psicológicas femininas na psique do homem, como, por exemplo, os sentimentos e humores instáveis, as instituições proféticas, a sensibilidade ao irracional, a inerente capacidade de amar, a faculdade de sentir a natureza e, finalmente, embora não menos importante, as relações com o inconsciente. (...) A anima pode simbolizar também um sonho quimérico de amor, de felicidade e de calor maternal (o ninho) - um sonho que leva o homem a ignorar a realidade." (In: Chevalier, Jean e Gheerbrant, Alain. Dicionário de Sìmbolos. Mitos, sonhos, costumes, gestos, formas, figuras, cores, números. 5ed. Rio de Janeiro, José Olympio, 1991. - p 421) Nando, inspirado pela força que vê nas mulheres, volta-se para um modo de ser mais feminino, já que julga estar aí os caminhos para o apaziguamento das dores humanas.
} 
uma perspectiva salvacionista, agora, só o amor profundo, carnal e espiritual, representa essa mesma perspectiva. Despejando tal olhar sobre o mundo, Nando auxilia muitas mulheres e homens a buscarem uma vida mais livre e feliz, dentre eles, Margarida, a professora, que tentara suicidar-se no mar:

“-Eu quero é morrer. Isso é que eu quero - disse Margarida.

- Quem se mata no mar reencarna em peixe - disse Nando.

-Eu quero morrer.

- Eu te solto no mar outra vez. Prometo. Mas primeiro me conta como é que uma moça mocinha como você quer deixar os meninos sem professora e virar peixe.

- Eu quero morrer, eu quero morrer

E foi então que Nando abandonou a palavra tão novinha e deixou as forças antigas se espalharem pela aflição de Margarida. Um corpo dócil, culto; e aquela barbárie de dor. Os dedos pela blusa molhada buscando o bico ressentido dos seios. Buscando o ventre em crispação rancorosa, virando contra seu peito patrício Margarida silvestre. (...)

Margarida foi ficando incoerente com o calor de Nando. Seu corpo encharcado do mar de suicídio mas de uma secura de deserto e trancado para a entrada da morte começou a reabrir, poroso.

Margarida pedregosa cobriu-se de anêmonas" (483-484)

Ensinando as pessoas a se desprenderem dos rígidos padrões sociais e, portanto, de alguns dos mecanismos de opressão, Nando entra em confronto com muitos dos valores impostos socialmente, o que lhe rende censuras por parte tanto dos mais conservadores, quanto dos colegas de esquerda: os 
primeiros, julgam-no imoral e pervertido; o segundos alienado e individualista. ${ }^{1}$

Entre uma possível postura reacionária, ou uma possível postura revolucionária, o protagonista deseja enterrar seu passado - embora ele saiba que um dia terá de retomar o trabalho abandonado - e fecundar seu presente com gestos que ele acredita representarem a pura doação de amor.

Com tal consciência sobre a função social das suas ações, Nando continua fazendo da imagem de Francisca o centro de sua existência, revivendo, cotidianamente, os ecos longínquos da história de luta de Levindo, e recriando-a na promoção de uma silenciosa revolução Fatigado do mundo e dos homens, a imagem de Francisca é o refúgio onde o protagonista procura se abrigar, o jardim onde quer se recolher. Nando retrai-se e ignora o acontecimentos cotidianos.

O movimento de retração é a única maneira que o protagonista encontra para repudiar o esfacelamento do seu universo pessoal pela ditadura. A desordem e o caos social contaminam a intimidade de Nando que ainda não conquistara o passo decisivo do despojamento de seus problemas pessoais e não conseguira encontrar-se no ser coletivo.

Nesse contexto, proporcionar aos outros um intenso prazer sexual torna-se o único vínculo de Nando com a sociedade. Através da devoção a Francisca

\footnotetext{
${ }^{1}$ As décadas de 60 e 70 caracterizaram-se fortemente, pela contestação de diversos valores e padrões de vida. Os ideais de revolução política eram acompanhados pelos ideais da revolução sexual, pela emancipação feminina, pela liberdade de expressão: “Um neo-existencialismo não pressentido na época convencia aquela juventude a rejeitar uma secular esquizofrenia cultural que separava política e existência, arte e vida, teoria e prática, discurso e ação, pensamento e obra. Essa talvez tenha sido a grande ruptura com a geração anterior - e uma das mais difíceis realizações de 68...” (In: Ventura, Zuenir. Op. Cit. p.31)

Porém, na esquerda, muitos eram os que condenavam as relações amorosas e os movimentos culturais de vanguarda, pois julgavam-nos profundamente mesquinhos diante do contexto histórico brasileiro definido pela arbitrariedade e pela violência física e moral. (ver: Gabeira, Fernando. O que é isso companheiro?. 35ed, Rio De Janeiro, Guanabara. 1988). Muitos dos companheiros de Nando figuratiza essa expressão da esquerda, quando, por exemplo, Padre Gonçalo ou Lídia tentam convencê-lo de que deve voltar à luta contra a ditadura, condenando o seu comportamento, segundo eles, alienado, individualista e frívolo.
} 
ausente e da esperança - que, pouco a pouco, esvaía-se - de poder reencontrá-la, o protagonista 'elabora o luto' ${ }^{1}$ da morte das suas utopias. Viver em equilíbrio com a natureza e oferecer às pessoas ensinamentos sobre o dom de extrair do sexo o prazer vital é a maneira que ele encontra para integrar-se aos que lhe rodeiam. Nando volta-se para si e para a comunidade que o circunda, já que não consegue admitir o poder de violência de que a humanidade desfruta e a inacreditável capacidade que ela possui para destruir a vida e homenagear a dor e a morte:

“- O que é que você está fazendo, Nando? Juro que não entendo nada. Estive com Jorge, que também não entende.

- Estou voltando ás origens dos erros - disse Nando - Aprendendo a viver em camadas mais significativas. Ensinando as pessoas a amarem, eu que aprendi, como você sabe, as duras penas. (...)

- Por favor, Nando, vamos deixar as frivolidades para outra vez. Otávio fugiu para o interior.

- Ele não tinha se asilado? - disse Nando - Não tinha fugido para o interior?

-Não sei ao certo Perdi contato com ele durante muito tempo. Mas agora sei que está no Brasil. Está organizando a revolta.

-É o que ele faz desde os dias da Coluna.

-O que é muito melhor do que passar o dia inteiro falando em mulheres e não sei mais que tolices. (...)

- O que é que se pode fazer o exílio, Lídia? O jeito é aproveitar o tempo e cavarmos em nós mesmos. Ás vezes a gente acha alguma coisa.

- Exílio é no estrangeiro, Nando.

\footnotetext{
${ }^{1}$ Embora Ernildo Stein trate da necessidade de as esquerdas aprenderem a elaborar o 'luto' dos ideais socialistas depois da queda definitiva da união soviética, sua análise contribui muito para uma reflexão em torno da consciência do fracasso das décadas de 60, 70 e 80. (In: Stein, Ernildo, Orfãos da utopia: a melancolia da esquerda. 2 ed. Porto Alegre, Editora da Universidade/UFRGS, 1996.)
} 
- Quando é a pátria da gente que viaja, não.”

Com a interioridade esgarçada por assistir a mais um desmoronamento dos seus sonhos, Nando não deseja voltar à luta contra o governo opressor, pois sente que é impotente com relação à força bruta da pátria. Julgando ser impossível transformar a realidade brasileira, a crise existencial do protagonista reflete a crise social: a convicção de que os oprimidos não são sujeitos nem da sua própria história pessoal, quanto mais da História nacional, desvincula o homem da realidade e esvazia sua subjetividade, tornando-a volúvel e frágil, facilmente manipulável pelas elites. O poder das elites e a fragilidade do indivíduo impedem, por sua vez, que o homem atue no sentido de transformar a sociedade e libertar-se da sua permanente condição de objeto dos processos históricos.

Coloca-se mais um problema fundamental da teatrologia de Antônio Callado, que se revela na necessidade de o homem fazer a sua história, biográfica e nacional, e na dificuldade de os brasileiros descobrirem a sua verdadeira história, sempre recriada, seja pelo Estado, seja pelos próprios cidadãos, que não suportam reconhecer as faces terríveis da sua gente:

"A América Latina não gosta do nome que tem por que não gosta de ser aquilo que é. São países que se consideram, todos e cada um, em eterna formação e em busca de uma identidade. Como já disse não sei quem, todos eles sabem muito bem a identidade que têm - mas não gostam dela. Preferem, por isso, fingir que ainda não têm nenhuma". ${ }^{1}$

\footnotetext{
${ }^{1}$ Callado, Antônio. Crônicas de fím do milênio. Or. Martha Vianna. Rio de Janeiro, Francisco Alvez, 1997. (p.90)
} 
Nando sente-se absolutamente marginalizado da violenta sociedade brasileira e perdido no mundo de Francisca, no desejo de amá-la e de ser amado por ela. Incapaz de perceber um sentido para sua vida e longe de seu centro, o protagonista representa o próprio Brasil, perdido em referenciais exteriores e dilacerado pela condução imoral de sua história, incapaz de projetar um futuro próximo e, menos ainda, definir o presente.

O país e o herói constroem-se, nessas condições segundo as pressões externar que sofrem. O Brasil fica à disposição de um pequeno grupo, que faz da terra generosa e da pátria mãe uma madrasta terrível e ingrata. Nando, que tem cada vez menos liberdade para optar pelas mudanças desejadas em sua vida, acaba partindo para a organização da luta armada no sertão, pois, se assim não fosse, não teria paz de espírito, seja porque seus companheiros desfilariam com as torturadas vidas pela revolução sonhada, ou porque a polícia o espancaria pelos vínculos passados, ou ainda porque não mais se consolaria da ausência de Francisca

O capítulo 'A praia', encerra-se com um jantar que Nando oferece para homenagear os dez anos da morte de Levindo. A ideia de ceiar a alma de Levindo, como um herói, um chefe indígena, que revive no dia de quarup como um ser mítico que inunda os homens comuns de força e sabedoria, vagava nas ideias de Nando há tempos. Porém, a necessidade de homenagear Levindo nasce da visita de Manuel Tropeiro, camponês que se dedicara a aprender as letras do alfabeto com Francisca nos tempos de outrora e que, apesar das terríveis torturas, não deixaria de lutar pela revolução social.

Constrangido por negar tão veementemente um novo engajamento com as esquerdas, enquanto Manuel Tropeiro entregava-se intensamente às lições 
Recebidas de Francisca, inspiradas na história de Levindo, Nando oferece o jantar para o revolucionário assassinado como meio de reconciliar-se com aqueles que ainda acreditavam na revolução popular.

Ao contrário das expectativas de Nando, tanto para Manuel e para os companheiros da esquerda, quanto para a polícia, o 'banquete' acaba representando o seu reingresso à luta das esquerdas. $O$ que deveria ser apenas um presente à Francisca, à memória de Levindo, á Manuel Tropeiro, põe fim ao que todos julgavam ser a 'dolce vita' de Nando e inaugura o doloroso processo do retorno à busca do seu centro e de um sentido verdadeiro para a vida, já que o ex-padre não conseguira encontrar a felicidade na realização plena da sua intimidade.

Por uma série de desdobramentos inesperados, o jantar promovido por Nando vira uma provocação ao Governo, agravada por coincidir com o dia da Marcha pela Família organizada por Ibiratinga. A esquerda tenta evitar que se realize o jantar, pois afrontaria abertamente o governo e levaria a repressão a vigiar mais cuidadosamente a movimentação da cidade, inibindo o possível crescimento da organização da luta armada. Indignado com tal situação, Jorge acusa Nando de ser irresponsável, mas o que ele não imagina é que esse clima em torno da homenagem que desejava prestar a Levindo desenvolvia-se à revalia do ex-padre.

A narrativa intensifica o ritmo dos acontecimentos, e qualquer gesto passa a ser indispensável para a composição de uma atmosfera, ao mesmo tempo, tensa e irônica. As imagens construídas acompanham a confusão da mente do protagonista, que recupera, cada vez mais frequentemente, o universo ligado às águas - os rios, as cachoeiras, os mares - e as sensações provocadas, outrora, pelo éter: 
“- E se o jantar der prisão? - disse Jandira.

- Não, não dá.

- Não fala assim comigo não, bichinho. Você sabe que pode ser preso dando um jantar de homenagem a um como é que chama? Subversivo. Ah, Jandira! Por que exigir em nome da simplicidade uma resposta assim de um homem colocado feito um rio num desnível, já na curvinha do barranco mas sem querer virar cachoeira? Nem o éter tinha a resposta. Não conseguia devolver o muro branco até reduzi-lo ao vitral. Como era mesmo o vitral que sobrava da catedral lentamente demolida desde a flecha até às pedras da rua? E o fole de três cores? O puro sopro anterior ao primeiro respiro?” (p.545)

Essa atmosfera prepara o capítulo seguinte e anuncia a segunda, e muito mais profunda, descida aos infernos do protagonista. Como já se previa, o jantar é invadido pelos policiais e Nando é espancado por Xiquexique. Quase morto, o protagonista é levado por Manuel Tropeiro e Raimunda, mais Margarida, Cristiana, Djamil, Amaro e Zeferino Beirão, a casa de Hosana e Deolina, que ficava escondida, pois ali preservava-se os segredos da Quinta dos Frades.

Nando conclui a sua última fase de amadurecimento no capítulo final do romance, 'o mundo de Francisca'. Completando a sua deseducação, o protagonista, convivendo com a ideia da sua própria morte, encerra um ciclo de sua vida, pois elabora o luto do fim do amor platônico por Francisca e redescobre todo o seu ser no mergulho profundo que faz em sua história de vida. Nando preenche as 'cisternas vazias' do seu mundo íntimo e, assim, 
consegue encontrar sentido na realidade que o cerca, o que o impele a engajar-se na luta armada.

Durante o tempo em que Nando encontra-se convalescente, as imagens aquáticas, que pontuaram todo o romance, avolumam-se num turbilhão mental, desdobrando-se em figuras ligadas a sua infância. Essa infantilização do universo do protagonista introduz uma nova perspectiva na narrativa, pois, se por um lado reforça a necessidade de se pensar a história psicanaliticamente, por outro, coloca as dificuldades de se compreender os 'heróis' que a pátria, violenta e intolerante, produz ao longo dos seus sucessivos episódios de terror. Por isso, numa perspectiva lukacsiana, Nando apresenta-se como um revolucionário em formação, um herói que só poderá constituir-se enquanto tal, se reconhecer todas as suas fragilidades e a necessidade de chegar ao fundo de si, ao começo da sua existência, à raiz dos seus problemas, à deseducação completa.

A recuperação do herói, já na clandestinidade, acusado de ter agredido os soldados do Coronel Ibiratinga, dá-se lentamente e as sensações e os pensamentos de Nando são filtrados pela simbologia das várias águas que lhe vão purificando a alma. O narrador abandona o leitor aos caminhos labirínticos da mente do protagonista e conforma o seu olhar à impossibilidade de decifrar uma lógica nos seus pensamentos pulverizados. A narrativa desenvolve-se, assim, lentamente, num movimento de avanços e recuos, procurando mimetizar a consciência do herói.

Embora consiga compreender o que dizem a sua volta, Nando está mergulhado em sua interioridade e não interage com a realidade, respondendo a seus amigos com tal apatia que esses julgam que ou ele iria morrer ou enlouquecer. O protagonista perde a memória dos fatos recentes, o 
que faz com que a viva intensamente seu passado remoto, relacionando todas as manifestações do presente com os fatos ocorridos num tempo anterior.

Nesse contexto, o aprendizado do herói deixa de ser fruto da experiência e da observação da realidade para desenvolver-se num movimento de aprofundamento nos recônditos de sua subjetividade:

“- Tem alguma coisa que te doa no corpo? Ou uma preocupação que não quer nos contar? Diga, Nando, tem alguma coisa te atormentando? Nando fez não com a cabeça. Se ele ao menos pudesse explicar. Aquela sangria de trevas tinha aberto nele um vazadouro. A solução era só uma, começar a voltar, a recolher as águas, engolindo os riachos que tinham entrado pelos lados, restituindo às nuvens as chuvas caídas, me espremendo, me afinando com jeito as margens onde eu cabia menino,a- largando as beiradas um pouquinho só. Enquanto isso o coco boiando no rio, tingindo o rio para que não se perca o negro.” (p.576)

Essa última parte do romance retoma os símbolos de 'O ossuário', porém numa inversão clara de significados. Num primeiro momento, Nando é cercado de cuidados por seus amigos, como o foi por Leslie e Winifred, mas o que ele extrai dessa relação de amor não é mais a revelação de um mundo desconhecido, é a necessidade de adaptar as suas expectativas ao que a realidade possibilita, banindo de seu imaginário o passado e o futuro gloriosos da igreja. Em um segundo momento, o protagonista, orientado por Hosana, visita a Quinta dos Frades, revendo os segredos do mosteiro com um horror nunca imaginado. E, ao final, Nando redescobre Francisca numa perspectiva social e utópica, não mais pessoal e individualista, pois ela passa a figuratizar um mundo a se conquistado. 
O jogo especular que se dá entre ' $\mathrm{O}$ ossuário' e 'O mundo de Francisca' deve-se, fundamentalmente, à relação que Nando mantém com o tempo e, portanto, com uma dada perspectiva utópica. No primeiro capítulo, Nando tem em seu imaginário a vida eterna e, nessa medida, adota um olhar místico sobre o real, adorando, passivamente, a Deus, e condenando o presente e a humanidade. Ironicamente, no segundo capitulo, essa eternidade torna-se circunstancial e, nos capítulos subsequentes, ele passa a analisar cada ação sua, a fim de fugir da repressão e garantir sua vida na terra, enquanto cresce a necessidade da luta armada contra o Estado e a distância da ideia de uma verdade mística sublime e transcendente.

Essa inversão do imaginário utópico do protagonista é explicitada na oposição Nando/Hosana. Se antes Hosana, o assassino, era quem dizia que a virtude era cômica e o ossuário uma cripta fedorenta, agora é ele quem guarda essa mesma cripta e quem protege Nando contra a ditadura. E se antes Nando, o devoto, era quem abominava a arma de Hosana e pregava o respeito aos símbolos religiosos, agora é quem adota a violência como forma de sobrevivência.

A descida de Nando à Capela da Quinta dos Frades concentra uma gama de significados que despertam, quando lá retorna sozinho, os seus traumas, fazendo com que ele recupere plenamente a memória e a vontade de viver. Contemplando uma sequência de mosaicos que iconografizam temas bíblicos, Nando os interpreta sob uma ótica absolutamente contrária à de Hosana, fixando-se na brutalidade das formas de violência apresentadas: crianças de Judéia massacradas por Herodes, o filho de Maria irado, a Crucificação, os apóstolos apavorados, Maria 'desgrenhada e convulsa de 
cólera' ameaçando Deus com o punho fechado, a dor de Madalena e 'Deus morto no chão. Um homem morto'.

Superando as duras críticas de Lukács contra o processo descritivo ${ }^{1}$, o que seria a mera caracterização dos quadros sacros torna-se, aos olhos do protagonista, a violenta e trágica história bíblica, que recupera, repentinamente, as violências sofridas pelos indígenas do Xingu, pelos presos políticos, por ele mesmo. A visão de Nando, colada à visão do narrador, une experiências da humanidade tão antigas como as narradas na Bíblia às suas experiências recentes. A fusão do passado remoto aos fatos recentes dá-se pelo reconhecimento de um fundo histórico comum a todas as épocas e a todos os povos, a interminável e terrível violência entre os homens. É essa experiência profunda que dá vazão às águas turvas do protagonista, trazendo à tona, num processo claramente psicanalítico, a consciência plena sobre si e sobre o mundo:

"E Deus morto no chão. Um homem morto. Nando olhou com fixidez a tábua imensa do meio, todo ele uma concentração de memória, e quando a si mesmo disse que precisava escrever a Leslie ouviu como num eco interminável os nomes familiares do passado recente, Levindo, Ramiro, Fontoura, Lídia, Januário e compreendeu a vingança mesquinha do espírito derrotado que não queria permanecer nem naquela quantidade indispensável ao normal funcionamento do corpo. Viu a cara odienta de Vidigal que com a boca cheia de fumaça berrava 'Francisca!' mas o berro não ressou nos ares como ressoara no porão, antes explodiu surdo e terrível no crânio de Nando. Nando sentiu as pernas moles, a testa úmida mas soube

\footnotetext{
${ }^{1}$ A descrição dos quadros da Quinta dos Frades serve muito mais à composição da história bíblica do que propriamente à caracterização das pinturas. O processo descritivo compromete-se, nesse contexto, com a composição de um trecho narrativo, o que se revela na interação entre o personagem e os quadros. Antônio Callado supera, dessa maneira, o que Lukács chama de aspectos meramente decorativos e, portanto, descartáveis, propondo uma leitura daquilo que se habituou qualificar como ‘descrição’ e 'narração'.
} 
que o combate estava findo.” (p. 582)

O herói compreende, nas palavras de Lukács ${ }^{1}$, a necessidade de aceitar o fracasso como condição inexorável da vida no mundo moderno, uma vez que a unidade entre homem e natureza foi rompida e o sentido da existência perdido. É por isso que Nando, seguindo as previsões lukacsianas a respeito do 'romance da aprendizagem', só conseguiu compreender qual era sua verdadeira busca a partir do momento em que aceitou os seus sucessivos fracassos e que, desiludido, interiorizou as faces terríveis do Brasil. Adaptado a esse panorama dramático, seu mundo subjetivo não mais entra em conflito com o mundo objetivo, ao contrário, ideias e ideais coincidem num intenso esforço d se reconstruírem novas perspectivas utópicas. Nas palavras de Lukács:

"Aqui, por consequência, o que condiciona o tipo de homem e a estrutura da intriga, é a necessidade formal de a reconciliação entre a interioridade e o mundo ser problemática e portanto possível, é ser-se forçado a procurá-la à custa de difíceis combates e de penosas vagabundagens, ao mesmo tempo que se deva estar, contudo, em condições de a alcançar. E é por isso que a interioridade que está aqui em causa se situa na verdade entre os dois tipos que acabamos de analisar ( o idealismo abstrato e o romantismo da desilusão ): a sua relação com o mundo das ideais é bamba, tão flutuan- te do lado do sujeito como do lado do objeto, mas a alma que já não apó- ia senão em si mesma não acaba o seu mundo numa realidade que é ou que deve ser perfeita, que se apresente como um postulado e uma entidade rival da realidade exterior."2

${ }_{1}^{1}$ Op. Cit. (p.p. 145-154)

${ }^{2}$ Idem, Ibidem (p.p. 155-156) 
A vida privada do protagonista alarga-se em direção ao contexto histórico e é Manuel Tropeiro, o homem 'tão inteiriço e firme', o homem da 'ironia sem malicia, silvestre', da 'ironia do melhor', que the mostra o caminho a ser buscado. E é também com ironia que vemos crescer aos olhos tanto dos policiais quanto dos esquerdistas a figura revolucionária de Nando, uma vez que ele mesmo sente-se diminuído diante da determinação e inteireza de caráter de Manuel. Essa inferiorização de Nando reflete-se no plano da narrativa, na medida em que, avançando para o final, vemos o personagem de Manuel ganhar contornos mais finos e nobres, enquanto o protagonista quase deixa de sê-lo, pois perde para ele o plano principal da narrativa.

Tal inversão sugere-nos a leitura de que os homens do campo estariam muito mais aptos a lutar contra a repressão, uma vez que sofriam frequentemente a violência do Estado independente de haver ou não um movimento mais urbano e intelectualizado contra o governo. Isso constatase, por exemplo, na caracterização dos camponeses, que, segundo o romance, suportaram torturas muito mais violentas - porque, como diz o próprio Ibiratinga, não podiam dispor de advogados e nem mesmo do interesse dos meios de comunicação - e que não titubearam, como Januário e Otávio, com relação à necessidade de continuarem na luta contra a ditadura:

"Nando abraçou um, abraçou outro, aqueles pedaços do mundo de Levindo, fragmentos do mundo de Francisca. Depois fitou os dois, as boas caras caboclas que antigamente desconhecia, que passara a conhecer um pouco, que hoje conhecia em essência (...) Há tempos não sabia deles dois, ou dos outros, os pequeninos, os únicos que sofrem no Brasil.” (p. 526) 
O homem do interior do Brasil mostra-se dono das terras em que vive, pois possui um forte vínculo com a pátria e não sofre de crises com relação à identidade nacional. Manuel Tropeiro, mesmo torturado, sabe quem é e tem consciência sobre as dificuldade de conquistar seu projeto utópico, mas encontra os caminhos para busca-lo sem passear por entre os desvios labirínticos da história. A confiança no seu primo Leôncio e nos seus outros tantos parentes do sertão do Brasil dispostos a esconder os revolucionários, nasce da compreensão de que eles possuem a sabedoria advinda de uma rica experiência de vida, dificilmente conquistada por um homem que não tenha o interior do Brasil, antes de tudo, dentro de si mesmo.

É com esse olhar de ‘dono' da casa que Manuel doa sua vida sem ver nisso a perda de algo, da felicidade ou dos prazeres, desafiando o próprio olhar de Nando, que vê a conduta revolucionária como martírica: "A gente pode morrer por uma causa, pensou Nando. É quase fácil. Dedicar-lhe a vida é outra coisa." (p. 527)

Se pensarmos na tipologia romanesca de Lukács, a narrativa, que acompanha a trajetória de Nando, parece oscilar entre o 'idealismo abstrato’ e o 'romance da desilusão', mas, em seu conjunto, compõe o 'romance da aprendizagem', uma vez que o herói termina por adaptar sua interioridade à realidade. Essa maturidade do protagonista revela-se na última cena, quando percebe que não possui nenhuma outra opção a não ser partir com Manuel Tropeiro para tentar organizar a luta armada, conseguindo plasmar-se ao caminho escolhido:

\footnotetext{
“Andavam agora num meio galope, Nando relembrando coisas da vida inteira mas sem sentir nenhuma ligação com os pensamentos e sentimentos que tivera: como homem feito que encontra um dia numa gaveta ca-
} 
dernos de colégio. Estava descontínuo, leve, vivendo de minuto a minuto. Só tinha como sensação de continuidade o fio de ouro de Francisca, assim mesmo porque era um fio fiado com astúcia na trama do mundo a vir. Não vinha propriamente do passado. Bateu alegre no peito com a mão direita, sustentando as rédeas na esquerda.” (p. 600)

Ao libertar-se do passado, Nando começa a se reconhecer no seu presente concreto, deixando as imagens antigas e as do futuro vagarem livremente, pois compreende que é, finalmente, um sujeito histórico, capaz de 'sustentar as rédeas' dos fatos e transformá-los. A violência como forma de combater o Estado ditatorial é interiorizada pelo protagonista, na medida em que sente estar em dívida para com os Ibiratingas que esmagaram a utopia da revolução pacífica, fechando todas as possíveis saídas da violenta e desumana situação social do Brasil.

Pouco antes de entrar na casa de praia para apanhar as cartas de Francisca, Nando encontra-se em meio ao carnaval de rua, o qual representa, alegoricamente, a onipresença da repressão militar - em meio à alegria popular, ele é quase preso novamente - e, ao mesmo tempo, a indiferença das pessoas frente a essa repressão. É nesse momento que Nando reconciliase com sua consciência tanto com relação à sua vida no mosteiro, quanto ao fato de, egocentricamente, ter vivido intensamente suas crises pessoais, entendendo que não havia desprezado o ser coletivo, uma vez que todos, ou quase todos, dedicavam-se à vusca do aprimoramente da felicidade pessoal, e, então, 'tinha de ficar alegre vendo que não era preciso salva um povo salvo'. Ironicamente, capenga e sem um olho, Nando confunde-se em meio às fantasias, mas essa celebração ao presente que é o carnaval, logo se esvai 
diante dos policiais de Ibiratinga, que lhe surpreendem numa emboscada dentro da casa.

Nando entende, ao observar a festa nacional, que jamais foi ou seria um mártir, exatamente porque não sabe expressar os anseios populares mão tão somente seus anseios pessoais. O protagonista junta-se a Manuel Tropeiro, com quem vai gestar a luta armada, menos por convicções socialistas do que por falta de opção, o que não anula, porém, o sentido que Nando encontra para o seu estar-no-mundo: a construção de uma sociedade justa e igualitária.

A perspectiva utópica de Nando revela-se individualista, mas, com o próprio protagonista afirma, são os motivos medíocres que levam a humanidade a lutar por motivos mais nobres, já que as sociedades modernas não mais permitem a identificação entre os homens e entre os seus ideais utópicos.

Antônio Callado aponta para a necessidade de reavaliarmos os projetos de revolução socialista sugeridos no contexto histórico brasileiro, bem como a de revermos a condição dos revolucionários que a história brasileira gerou ao longo dos seus violentos anos, a começar pelo genocídio indígena. Morta a possibilidade de se construir uma perspectiva utópica social, o autos parece contar com a viabilidade de, individualmente, cada qual assumir um fio da longa colcha de retalhos que é o Brasil, extraindo das ações miúdas o necessário sentimento de solidariedade entre todos os sujeitos históricos, ainda que a única resposta possível ao poder repressor dos anos 60 e 70 tenha tido que ser, nas palavras de Jacob Gorender, a luta armada:

"Se quiser compreendê-la na perspectiva da sua história, a esquerda deve assumir a violência que praticou. $O$ que em absoluto funda- 
menta a conclusão enganosa e vulgar de que houve violência de par- te a parte e, uns pelos outros, as culpas se compensam. Nenhum dos lados julga pelo mesmo critério as duas violências - a do opressor, por- que inexiste opressão sem violência cotidiana incessante. A ditadura militar deu forma extremada à violência do opressor. A violência do oprimido veio como resposta"1

É esse terrível desdobramento do Estado ditatorial que veremos ser desenvolvido em Bar Don Juan. Estado que já se anuncia trágico na conduta exacerbadamente violenta dos policiais de Ibiratinga e nos enfraquecimento da esquerda com o exílio de alguns e a morte de muitos outros.

$\overline{{ }^{1} \text { Gorender, Jacob. Op. Cit. (p. 235) }}$ 
2. A reciclagem das águas: Bar Don Juan, entre o

'idealismo abstrato' e o 'romance da aprendizagem'

"[ Revolucionário ] é aquele que junto à inteligência, à energia, à lealdade, ao espírito de conspiração possua também a paixão revolucionária e o diabo no corpo". (Bakunin, trecho de carta transcrito do livro Bakunin: sangue, suor e barricadas, Sérgio Augusto Queiroz Norte) 
Depois de Quarup, Antônio Callado, em 1971, publica Bar Don Juan, romance que busca registrar os anos do auge do fechamento da ditadura militar e as suas consequências para a esquerda, que, diante da inesperada violência do estado ${ }^{1}$, entra em profunda crise. Sem tempo e nem meios para viabilizar uma ampla discussão e buscar caminhos para reunir os diferentes grupos da oposição numa única frente contra a ditadura, a esquerda se fragmenta e a luta armada, nascida mais da necessidade de combater o terror do que propriamente de um desejo utópico, haja vista a urgência com que foi realizada, diluiu-se nas inconciliáveis divergências entre as facções revolucionárias:

“À exceção do Comitê Central do PCB, a esquerda considerou a falência do caminho pacifico um fato provado. Seguia-se que a luta armada, não travada contra o golpe de direita, tornava-se imperativa quando os golpistas já tinham o poder nas mãos. Se tal raciocínio se cristalizou em axioma nem por isso unificou a esquerda. À questão da luta armada se acrescentavam outras, concernentes aos antecedentes partidários e doutrinários, a influências teóricas de origem nacional e internacional, pressões de países socialistas, limitações regionais etc."2

Preocupado em compor outra história que não a divulgada pelos governos, Callado resgata as vozes sufocadas pela opressão do Estado sem, porém, idealizá-las. O contexto que se procura resgatar na construção dos personagens e na própria construção narrativa apresenta uma grande preocupação com a elaboração da memória histórica dos oprimidos, que não

\footnotetext{
${ }^{1}$ As esquerdas não conseguiram prever a arbitrariedade e a violência com que o Estado passou a agir depois do Ato Institucional número 5. (VENTURA, Zuenir. Op. Cit.)

${ }^{2}$ GORENDER, Jacob. Combate nas trevas. A Esquerda Brasileira: das ilusões perdidas à luta armada. São Paulo. Ática, 1990. (p.79).
} 
tiveram tempo, ao menos, de compreender os caminhos que, na época, a esquerda tomava.

O resgate da história das esquerdas revela não somente a busca da construção de uma memória histórica, mas também a necessidade de construir uma reflexão sobre os movimentos revolucionários. $\mathrm{O}$ desenvolvimento do romance vai, pouco a pouco, desenhando uma visão bastante ousada das ações das esquerdas, uma vez que não as poupa de críticas agudas contra o comportamento dos revolucionários, os quais, agindo isoladamente, perdem-se em seus cotidianos e em seus problemas pessoais.

É com angústia que assistimos aos movimentos de João, o comandante do grupo revolucionário composto por Laurinha, sua companheira, Mansinho, Murta, Geraldino e Mariana, Aniceto e Joelmir, pois mesmo o leitor desavisado antevê o fracasso das suas ações armadas.

A compreensão do esgarçamento da esquerda evidencia-se na medida em que a narrativa explicita os graves equívocos dos revolucionários, proporcionando aos leitores o distanciamento necessário à análise dos fatos, o que era impossível de ser conquistado pelos envolvidos na luta armada, dadas as condições históricas da época (à exceção de Gil, que abandona o grupo por reconhecer os tortuosos caminhos traçados pelos companheiros).

Retomando os mecanismos de Quarup, a narrativa aponta para a relação problemática consolidada no mundo moderno entre o homen e a realidade, o que, como vimos, segundo Lukács ${ }^{1}$, teria sido a condição para a origem do romance moderno. Tal relação torna-se, porém, em Bar Don Juan, muito

${ }^{1}$ Georg, Lukács. Op. Cit. (p. 109-115) 
mais aguda, pois, aqui, coloca-se em risco não apenas a sobrevivência das utopias sociais, como em Quarup, mas também das pessoais.

O protagonista do romance, João, figuratiza o provável destino de Padre Nando, e os demais personagens figuratizam não apenas a chamada 'esquerda festiva', mas também o próprio homem moderno submetido às tragédias brasileiras. Os revolucionários, como Nando, têm os mais diferentes interesses na Revolução, que vão desde o auto-engano, o desafogamento de frustrações pessoais, a ocupação de um tempo ocioso, a necessidade de preencher a vida de algum sentido, até o desejo de tomar o papel de sujeito da história e transformar radicalmente as estruturas sociais. São esses diferentes interesses e a dificuldade de reconhece-los que favorecem, ainda mais, a dissolução da esquerda, pois, ao mesmo tempo em que forjam um engajamento romântico na luta armada, fazem com que o significado da Revolução se perca no embate entre a individualidade e o todo social:

"Era a primeira vez que o prendiam na companhia de Laurinha mas sozinho fora preso antes duas vezes, o que não lhe impedira de sentir de novo, preso com ela, a mesma áspera alegria das ocasiões anteriores, a alegria de ser posto à prova. Não ia falar, não ia dizer nada, continuariam sem confirmação seus contatos com os cubanos. Quase apostava, enquanto os tiras revolviam papéis, olhavam atrás dos quadros e recolhiam livros para levar, que Laurinha se sentia exaltada. Com uma pontinha de medo talvez, mas feliz.” (p.p. 4-5)

\footnotetext{
1 'Esquerda festiva' era uma expressão inventada pelo colunista Carlos Leonam em 63, durante a primeira grande festa que Jaguar organizou. O falecido ministro San Thiago Dantas acabara de decidir que havia duas esquerdas: 'A Esquerda positiva e a esquerda negativa'. Leonam, um atento cronista do comportamento carioca, estava dançando quando teve a ideia. Correu para a mesa de Ziraldo e disse: 'Tem outra esquerda, é a esquerda festiva.' (In: Ventura, Zuenir. 1968: O ano que não terminou. Rio de Janeiro. Nova Fronteira. 1988. - p.47)
} 
Desintegradas muitas das histórias pessoais pela violência do estado nacional, os conflitos sociais tornam-se obscuros para uma população que não consegue administrar as profundas frustrações causadas pela caótica realidade brasileira: os personagens revelam-se perdidos num universo de verdades e de valores estilhaçados, onde surge um (quase) intransponível abismo entre o mundo subjetivo e o objetivo.

João é o representante desse homem, imerso na elite ilustrada e conquistada pelas ideias das revoluções socialista e cubana. Cego para a realidade brasileira e incapaz de perceber o poder e a força do regime, o protagonista enxerga o mundo segundo sua subjetividade e, por não conseguir apreender as condições reais que o rodeiam, julga-as estarem erradas. A autonomia do herói fica, então, condicionada à crença de que há valores verdadeiros a serem conquistados e, para tanto, passa a busca-los de forma arbitrária num universo de verdades degradadas ${ }^{1}$.

Este é o 'demonismo' lukacsiano de João que se revela num excesso de atividades, as quais, muito pouco pensadas e elaboradas, são, às vezes, levadas a cabo por uma absoluta falta de horizontes. Tal atuação do protagonista, que acredita estar lutando por causas sociais, determina o 'grotesco' da sua trajetória, pois ele experimenta momentos de lucidez e percebe a degradação do universo, intuindo que a sua ação está condenada ao fracasso, bem como a revolução:

"Não é isso não, Geraldino, é que nossa organização é de outro tipo.

Nós não sabemos pensar consecutivamente. Não conseguimos produzir um feixe de pensamento que analisa. Nossa barreira de vísce-

\footnotetext{
${ }^{1}$ LUKÁCS, Georg. Op. Cit.
} 
ras e de sangue é densa demais. A gente pensa com o corpo inteiro, dentro do problema. Eu sei que isto nos torna cômicos para a outra família humana, a família dos que ganham a guerra, mas é assim que somos.” (p. 137)

A consciência crítica do João permanece, porém, como ele mesmo diz, distante demais da superfície da realidade e, por isso, não altera em nada o curso de seu programa previamente formulado. Ignorando suas próprias análises, João procura organizar, a partir do perímetro urbano, focos revolucionários no interior, a fim de cumprir a tese de que o Brasil detonaria a revolução em toda a América Latina. Age com essa perspectiva em mente, mas, por outro lado, percebe o abismo entre o contexto histórico brasileiro e o latino-americano e os discursos das esquerdas e sabe que o seu próprio grupo está longe de entender a Revolução sonhada e de conseguir reconhecer nela suas utopias pessoais.

As fraturas dessa realidade revelam-se na própria linguagem dos revolucionários, os discursos interpessoais não encontram um ponto de convergência, não se constroem em torno de um tema comum, ao contrário, cada qual impõe uma compreensão dos fatos gerada, exclusivamente, por seus universos subjetivos, sobrepondo uma impressão à outra. A comunicação não se efetiva plenamente e o que se tem é um desencontro de vozes, em que se externa os desejos mais íntimos de cada personagem e que impede a troca de experiências e a construção de uma aprendizagem social.

$\mathrm{O}$ fato de os revolucionários permanecerem ensimesmados e de reagirem aos fatos quase de maneira inconsequente expressa a dificuldade de eles reformularem as suas inadequadas visões de mundo, impregnadas da intensa sensação de fracasso, já que as subjetividades e os horizontes utópicos 
desses homens esmagados pela violência física e moral. Diante dessa sensação, os homens assumem, num jogo de máscaras, papéis que lhes possibilitem sobreviver aos olhos dos outros e de si mesmos.

Daí o conflito que se lê nesta teatrologia de Antônio Callado entre intimidade dos personagens e a realidade. $\mathrm{O}$ interesse do autor na exploração das crises pessoais dos personagens surge da necessidade de se investigar as causas que levaram o projeto revolucionário brasileiro à falência, assim como as que impossibilitaram os oprimidos e marginalizados de assumirem o papel de sujeitos históricos.

Nesse sentido, Bar Don Juan parodiza Quarup, pois revela os terríveis equívocos da história daqueles que, como Nando, engajaram-se na luta armada na expectativa de encontrar um sentido para as suas vidas pessoais. Os revolucionários de Bar Don Juan são o espelho de Nando, a imagem às avessas daquele que imaginava conseguir construir o novo porvir através da opção (única e última) pela luta armada.

O sucesso do ex-padre ao conseguir reconciliar, através das experiências vividas, sua intimidade ao contexto histórico é revista em João e nos companheiros, pois eles, com o endurecimento da ditadura, já não encontram mais as condições históricas que Nando encontrara: o medo e o terror impedem-nos de reconhecer seus fracassos pessoais e sociais, para que, como Nando, pudessem superá-los. O aprimoramento das técnicas de perseguição e tortura torna o tempo, urgente demais para que os personagens pudessem reeducar seus olhares sobre o mundo.

Vimos que Nando engaja-se na luta armada porque, perseguido pela polícia, não desfruta de nenhuma outra opção de vida, e porque a única saída para o país, sob a ótica dos revolucionários, não estaria mais na luta pacífica. 
A ditadura encurrala os homens e a eles resta apenas buscar a revolução armada, seja pela necessidade de reafirmar a individualidade destruída pelo violento poder repressor, seja pelo desejo de transformar a história brasileira, ou seja por uma questão de sobrevivência.

Corrompendo as propostas de Quarup, a história de João parte do confronto violento entre o estado e a esquerda e inverte os significados da conduta de Nando: se o ex-padre apresenta uma forte tendência e alienar-se e isolar-se da realidade brasileira, desejando manter-se passivo, o chefe do grupo do bar 'Don Juan' não pondera as possiblidades de acerto ou de erro e é extremamente ativo.

É o aspecto temporal que proporciona, por um lado, ao protagonista de Quarup superar seus equívocos e, por outro, aos revolucionários de Bar Don Juan ficarem reféns do processo histórico, gastando a vida em uisquerias e conflitos passionais:

\footnotetext{
“Gente doida, pensou Karin, com sua vida pessoal intensa, à espera de não sabem que da vida coletiva que justifique a preciosa perda de si mesmos. Lagunas esperando um oceano à altura" (p. 85)
}

Essa é a impressão da estrangeira Karin, que avalia a vida dos amigos revolucionários como um grande equívoco, assim como Winifred e Leslie avaliam o comportamento de Levindo ou mesmo de Nando. O indivíduo, apesar de estar muito distante da coletividade, tanto assim que ela pouco aparece em ambas as narrativas, julga-se autorizado a falar em nome da maior parte da população brasileira, restringindo o mundo a seus desejos pessoais. 
João não consegue avaliar o mundo a sua volta, pois está impossibilitado de superar sua 'cegueira'. Isso o faz crer que é o mundo que está absolutamente errado e não a sua conduta na realidade, fugindo à busca incansável de Nando de conhecer a si e ao contexto histórico brasileiro.

O comportamento do protagonista de Bar Don Juan compõe o que Lukács chama de ‘idealismo abstrato’. Segundo o crítico, o herói não consegue agir sobre a 'essência do mundo', porque projeta sobre a realidade algo que não lhe é próprio e luta para transformá-la sem antes, porém, conhecer os seus verdadeiros mecanismos ${ }^{1}$. A inadequação do herói ao contexto histórico em que vive estende-se aos demais personagens - à exceção de Laurinha, como veremos adiante - , os quais se tornam, em muitos momento das narrativa, protagonistas.

A multiplicação de protagonistas, ainda que a condução do enredo privilegie João, colocando-o, até certo ponto, como personagem principal, aponta para os vários sujeitos da ação narrativa. A coletivização do sujeito gera uma desordenada sobreposição de discursos, muitas vezes antagônicos, trazendo à tona a falta de unidade entre os grupos de oposição e a ausência de uma utopia coletiva.

A fragilização do projeto esquerdista que se revela em Bar Don Juan arrebanha simpatizantes interessados, prioritariamente, em darem um rumo a suas vidas tão carentes de sentido e proporciona a composição de uma frente de resistência bastante frágil e cheia de contradições.

O espaço que concentra as atenções do leitor na primeira parte da narrativa é um bar, batizado pelo dono de 'Don Juan' em homenagem a João, o romântico e incansável paquerador das noites cariocas. Nesse bar, em meio a

${ }^{1}$ LUKÁCS, Georg. (p.p. 109-114) 
profundos goles de uísque e a fofocas sobre mulheres, João convida e convence alguns amigos - que vivem suportando intermináveis ressacas - a formarem um grupo revolucionário.

Até o 'leão da chácara' do 'Don Juan', Aniceto, ou por não ter outras ocupações, ou por gratidão a João por ter arrumado um abrigo e um emprego, quando chegou de Alagoas fugido da polícia, segue as orientações do revolucionário, que o induz a participar da revolução, sem, porém, ter conseguido convencê-lo dor fins a que se pretendia chegar o movimento. É o que se lê na cena em que Aniceto falsifica garrafas de uísque, alegando assim proceder para arrecadar dinheiro para a revolução 'de João':

“-Que é isso, Aniceto? Virou médico?

-Não, enfermeiro de garrafa de uísque (...)

- Aniceto, meu filho, isto dá cana. E é uma falta de respeito. Uísque escocês é água benta de arroio que corre em terra de turfa. Tem gosto dos seixos dos riachos de montanha, assim como o xerez tem gosto das sofridas pedras da Andaluzia, como diz teu patrão Andrés. No mundo salvo do futuro só se vai manter uma tirania, um controle: o do uísque da Escócia e do vinho do Jerez de la Frontera, para todos tenham sua garrafa.

- E como é eu a gente chega lá, João?

- Lá onde?

- Lá nesse mundo de xerez e de uísque para a cabroeira toda?

-Você ainda não acredita na revolução? Logo você, meu instrutor de tiro?

- Acredito, desde que haja dinheiro para fazer ela, quer dizer a revolução.

E este serviço aqui ajuda. Como eu não assalto bancos faço finanças assim. O velho Andrés acabou concordando.” (p. 28) 
Geraldino soma-se aos exemplos do frágil compromisso que os integrantes do grupo tinham com a revolução. Tendo abandonado a batina, o ex-padre, culpado e amedrontado pelas figuras divinas, não se esquecia daquela por quem se apaixonara e a quem gostaria de juntar-se. Porém, vendo essa como uma possibilidade remota, Geraldino decide juntar-se a João, para, ao menos, tranquilizar sua conturbada consciência.

$\mathrm{O}$ enfoque descentralizado do narrador mimetiza a impossibilidade de os homens se identificarem seja uns com os outros, seja com o próprio espaço em que vivem, seja com as causas a que de dedicam, favorecendo ainda mais a violência do Estado opressor. Com tal violência sobre as lutas coletivas, o individualismo torna-se a única saída para minimizar os dramas da esquerda. Cria-se, então, a armadilha: os homens buscam a revolução como fuga para suas frustrações pessoais, mas, ao se depararem com a repressão, recolhemse às individualidades.

Jacinto admira a conduta revolucionária do seu irmão, que faz assaltos a bancos com o fim de viabilizar a luta armada. Porém, a construção do personagem Mansinho, ao longo da narrativa, não se dá prioritariamente em torno de seu engajamento político, mas das suas tramas sexuais e das suas fulminantes paixões. A sua caracterização como um soberbo paquerador, volúvel e infiel, flagra a relação superficial que mantém com o mundo e com a própria revolução. Os infinitos jogos que ele mantém com as mulheres, em especial com Mariana, a quem roubou do amigo Gil, estendem-se ao seu comportamento político, uma vez que ele não se guia por nenhum valor moral nem ético, mas apenas por uma incrível necessidade de preencher carências: 
"E pensar que iniciara a sua carreira de salteador num desespero pessoal que seu consumo seletivo e intensivo de mulheres não consolava mais! Tinha desejado Mariana, sem dúvida, mas tinha sobretudo agido magicamente ao furtá-la de Gil Setúbal: na obscura esperança de participar, pelas entranhas de Mariana, do gênio de Gil(...) Escrever como Gil não escreveria nunca mas como revolucionário triunfante talvez entrasse de herói num livro de Gil. Depois do roubo de Mariana tal possibilidade ficara remota. Só lhe restava a revolução, os bancos a assaltar, a vocação descoberta através de tão tortas linhas.” (p.p. 88-99)

Vivendo de pequenos desafios e aventuras, Mansinho não consegue avaliar os acontecimentos e tampouco descobrir a natureza das suas carências. É ele mais um pretenso artista dos assíduos frequentadores do bar Don Juan, todos eles, à exceção de Gil, fracassados: Mansinho, com sua escrita débil; Murta, ansioso por fazer um filme, cujo o tema seria 'o Brasil demente da realidade', e que não consegue sequer concretizar o esboço do seu projeto; e João, que deseja concluir um livro de índices remissivos a provérbios da América Latina, encalhado na letra ' $V$ '.

Gil é o único artista realizado do grupo, mas é também o único a abandonar os trabalhos revolucionários. Reconhecendo no pensamentos e nas intensões dos companheiros disparidades e graves equívocos, não pode ignorar que todos, inclusive ele mesmo, preocupam-se, essencialmente, com seus projetos pessoais, e que caminham em direção ao projeto político revolucionário antes de mais nada porque desejam revolucionar suas intimidades. Afinal, Gil é quem traz à luz o que todos sabem mas não compreendem: a impossibilidade de conduzirem a História do país e a história de suas próprias vidas: 
“- O Brasil é um urso que hiberna inconscientemente, vivendo das gorduras murmurou Gil. Nós somos no máximo pulgas no pelo dele. O Brasil de hoje só terá a história que eu lhe der. Eu posso inventar o Brasil aprofundando aquilo que ele é. Mas não posso inventar fatos históricos.

- A revolução a gente tem que fazer - disse Geraldino.

- Pois então façam -disse Gil- Fidel fez a revolução dele. Cuba já dava um romance. Mas essa atividade de aliciar patuscos para roubar metralhadoras e assaltar um banco ou outro e depois não acontecer nada, insto não leva a coisa nenhuma. As anotações que estão aí, se vocês não levarem, vão para o fogo. Não posso usar nada desse material em outros livros porque vocês, a menos que mudem, só chegariam ao desenvolvimento de vocês próprios mediante a revolução. Eu não quero escrever um livro sobre pessoas que se imaginaram feitas para produzir história e viveram vidas frustradas num país pré-histórico." (p.p. 122-123)

A revolução no Brasil é, para Gil, um mero projeto, tão longe de se realizar como a própria ideia de nação brasileira. Idealizando o devir brasileiro, que consolidasse a tão procurada identidade nacional, o personagem teme pela abstração desse sonho diante da fragilidade dos revolucionários.

João traz consigo essa contradição, compondo, em relação a Gil, um quadro irônico. Extremamente desumana, a lógica do sistema repressor impede que o protagonista consiga pensar um projeto viável para a transformação do Brasil. Apesar disso, João caracteriza-se pela ação e praticidade. Gil, ao contrário, tem o tempo suficiente para refletir sobre a revolução, mas não consegue mobilizar seus companheiros e tampouco orientá-los para novas estratégias de luta. Ele mesmo se reconhece impotente para escrever romance da revolução brasileira, o que aponta para a incapacidade de os comunistas construírem e manterem uma memória 
histórica e de, através dela, aprenderem a superar os fracassos e reconstruírem a utopia coletiva. ${ }^{1}$

A sensação de impotência do escritor, já consagrado pela opinião pública, por não conseguir narrar as histórias do grupo do qual ele mesmo participou, anuncia o que irá ser o tema fundamental de Reflexos do Baile: a impossibilidade de o narrador organizar os fatos e de construir a história segundo o ponto de vista dos vencidos num sistema corrompido pela ação desintegradora da luta entre opressor e oprimido, prevista, segundo Lukács,na própria concepção das sociedades modernas.

Se Nando, em Quarup, sofre profundas transformações em sua consciência, humanizando-se e adequando suas ações à realidade vivida é porque torna-se convicto de que o homem é capaz de transformar a história de um país, desde que descubra suas verdades e contradições e as interiorize como partes de si mesmo. Para tanto, Nando mergulha em si e na realidade brasileira, para compreender os mecanismos dos universos íntimos e sociais, o que se torna possível à medida que consegue absorver e trocar

\footnotetext{
${ }^{1}$ A figura de Gil abre uma discussão a respeito da função do intelectual, a qual foi bastante explorada, em diferentes artigos e entrevistas, por Antônio Callado. $\mathrm{O}$ escritor entendia que o intelectual deveria comprometer-se com o seu processo histórico, principalmente em países cuja democracia e a igualdade social estivessem ameaçadas, participando da construção do projeto de uma nação ("Acho que o escritor deve fazer aquilo que ele deseja fazer. Se a ideia é fazer poesias herméticas, teatro do gênero lonesco, acho perfeito. Muito pior é ele querer se fazer de outro tipo de escritor, que ele não é. Agora eu acho que um intelectual, sobretudo num país como o Brasil, não tem o direito de se eximir".) O intelectual, zelando pela memória histórica de um povo e analisando as suas necessidades e desejos utópicos, teria de engajar-se numa luta pela construção de uma identidade nacional e de uma sociedade justa. Esse é o conceito de 'intelectual' que passou a imperar a partir das atitudes de artistas como Zola ou Brecht.

Angel Rama resume esse conceito na função 'reguladora dos processos críticos', capaz de rechaçar estruturas arcaicas e gerar outras fundamentações ideológicas: "Las ideas vencen a las ideas pero solo las armas destruyem a las armas. Este pensamento de Marx, tantas veces citado, no deja de reconecer el papel preponderante que em la pugna histórica cabe a las ideas, las que cumplen una etapa previa y central en el proceso de transformacion de las sociedades. Como ya lo probara el paradigma dieciochesco en el ciclo de las revoluciones burguesas, a los intelectuales correspondió um exhaustivo, impecable análisis que acelero la disgregación del 'ancien régime': sus injusticias , sus fallas, sus contradicciones, su esencial arcaísmo respecto a los nuevos sectores actuantes fueron evidenciados en el campo de la cultura, transformándolo en una Bastilla indefendible e invivible. Paso prévio a la proposición de nuevas formas sócio-culturales.”. (In: RAMA, Ángel. Lá geración crítica: 1939 - 1969, Montevideo, ARCA Editorial, 1972. P.p. 16-17)
} 
experiências com o outro. É esse intercâmbio de experiências que desperta Nando para as transformações que lhe ocorrem, haja vista o papel fundamental de Winifred, de Leslie, de Francisca ou mesmo de Levindo.

Em Bar Don Juan, destruídos os canais tradicionais de comunicação ${ }^{1}$, uma vez que se encontram absolutamente bloqueados pela ação desintegradora da repressão, fica impossível a transmissão, de pessoa a pessoa, das experiências vividas.

Essa impossibilidade de cruzar experiências, confrontá-las e soma-las impede a renovação do repertório social e reduz a memória de um povo a lembranças esparsas e longínquas. Um homem deixa de ter motivos para identificar-se com um outro, já que não consegue perceber os vínculos que os ligariam e que encontra mais um repertório comum que lhe dê sustentação para compreender as histórias alheias e com elas promover a relação entre ensino aprendizagem social. Esgarça-se a identidade nacional, que promove, segundo Walter Benjamin ${ }^{2}$, o absurdo e o terrível empobrecimento da vida humana.

O grupo revolucionário não conhece as histórias brasileiras, pessoais e sociais, nem mesmo consegue conhecer os acontecimentos presentes, e, por isso, isolados, não podem rever sua visão de mundo e reconhecer erros e fracassos passados. A impossibilidade de se fazer uma autocrítica e de mudar em função dela nasce da falta de tempo/espaço que os revolucionários sofrem, pois reconhecer os equívocos representaria tornar-se mais suscetível ao inimigo.

\footnotetext{
${ }^{1}$ Walter Benjamin desenvolve preciosas reflexões a respeito da memória histórica e das consequências que a 'modernidade' teve sobre ela. (In: BENJAMIN, Walter. Magia e técnica, arte e política. Ensaios sobre literatura e história da cultura. 7 ed, São Paulo, Brasiliense, 1994 - Obras escolhidas. Vol. 1)

${ }^{2}$ BENJAMIN, Walter Op. Cit. (p.p. 114-119)
} 
Em Bar Don Juan, os devaneios interiores a que Nando se lança são duramente evitados e as críticas feitas contra o movimento não são ouvidas pelos revolucionários, nem mesmo as que Gil, o desertor do grupo, faz. Laurinha, a companheira de João, é a única que sente os conflitos vividos pelas esquerdas, mas não os quer assumir para não ter que reviver as dores do estupro quando foi presa pela repressão. É por isso que ela procura distanciar-se das ações do grupo e alienar-se da realidade, passando horas e horas a observar a movimentação das crianças, belas e saudáveis, no amplo jardim com piscina da casa do vizinho alemão.

A companheira de João busca refugiar-se nesse espaço de aparente equilíbrio e tranquilidade, utando para deixar-se contaminar pela alegria das crianças e para esquecer-se da violência que o policial, Salvador, cometer contra seu corpo e sua alma. Laurinha tenta recuperar a paz de espírito perdida, ainda que tenha consciência de que a fuga da sua história de vida em nada contribua para a reconstrução da sua intimidade, esmagada pela ação da ditadura.

A personagem vive em profunda contradição, pois seu presente, o convívio com os revolucionários e o amor por João, não a autoriza a desvencilhar-se do passado, a não ser que, como Nando o fez e como ela mesma aprenderá mais tarde, fosse a seu encontro e o reelaborasse interiormente. Aliás, o refúgio espiritual - e artificial - de Laurinha, prepara-lhe uma ironia do destino muito mais terrível, pois uma das crianças morre afogada na piscina:

“Laurinha esperou que João voltasse ao interior do apartamento para ir á janela. A piscina tinha sido soterrada, tinha desaparecido, como se nunca houvesse existido. Do grande portão até o centro do gramado havia o sulco das rodas do caminhão que trouxera terra e mais terra liquidar a 
piscina, apaga-la da memória das pessoas, enterrá-la para puni-la de haver feito enterrar a menina. A casa estava toda fechada, portas, janelas, garage, tudo, uma casa sem teto, sem olfato, sem ouvido, apenas o gosto daquela terra que entrara pelos olhos azuis da piscina. A casa tinha morrido com a menina" (p. 91)

Debatendo-se contra a dor, Laurinha fecha a janela e recobra os ânimos imaginando um outro ponto de fuga, a viagem que faria com o grupo revolucionário para Corumbá, a fim de que preparassem o encontro com outros revolucionários latino-americanos. Laurinha, como João, Murta, Geraldino e todos os outros, tentam evitar o encontro com a dor e a frustração, mesmo cientes da sua soberana existência.

Por entre assaltos a bancos, prisões repentinas e noites embriagadoras no bar Don Juan, os revolucionários aguardavam algum sinal, vindo não sabiam bem de quem, para que pudessem finalmente concretizar a revolução. Junto a eles, outros revolucionários também esperavam na Serra mineira de Caparaó o aviso de João para tirarem a poeira das armas guardadas e derrubarem o poder opressor.

Joelmir representa esses outros revolucionários do interior do Brasil, o qual, convencido da necessidade de se fazer a reforma agrária e de anular os enormes abismos sociais, aguardava as ordens da cidade a fim de iniciar a luta pela conquista da sua utopia que julgava ser coletiva. Porém, a espera infindável agita os espíritos dos revolucionários e desperta neles a desconfiança de que a revolução não representava os anseios populares e de que pouco deveriam apostar no seu sucesso. 
Depois de aguardar o sinal de João por exatos catorze meses, Joelmir vê os companheiros caírem nas amarras da repressão, já que não percebiam mais a necessidade de manterem-se escondidos numa situação de absoluto marasmo e decide partir para reconstruir sua vida pessoal.

Joelmir casa-se com sua meia-prima, Valdelize, mas, não muito tempo depois, João finalmente aparece para requerer as armas que estavam sob sua responsabilidade, alegando que elas deveriam ser levadas para o Paraguai, pois lá seria detonada a revolução latino-americana:

“- É o que carnaúba, como eu aprendi no Norte, dá cêra para guardar na sua árvore a água, queé pouca. Aqui no Pantanal água sobra. Por isso é que o carandá não dá cera, não é mesmo?(...) Assim são as coisas- disse Joelmir. - A gente dá água à carnaúba e ela não faz mais força, vira ca- randá largada aí pelos campos. Revoucionário sem ocupação também não dá mais cera não, João. Os guerrilheiros da gente aqui virou tudo carandá.” (p. 102)

Os tortuosos caminhos que a revolução tomava foram expulsando os que compreendiam-na e desejavam-na verdadeiramente. Mas Joelmir, mesmo ciente da desorganização e da fragmentação do movimento revolucionário, não consegue abandonar sua utopia e envolve-se novamente com o grupo diante da proposta de João de atravessar o rio Paraguai para levar armamentos aos revolucionários que estavam na Bolívia e juntar-se a eles.

A movimentação dos que promoveram a revolução cubana nas fronteiras anima João e a proximidade do companheiro Che Guevara preenche suas ações, aos olhos do grupo que comandava, de significados heroicos. Porém, 
vários sinais previnem João de que, ao invés de heroica, sua ação seria suicida, o que o personagem parece intuir quando descobre os resultados so assanto ao banco de Corumbá, com a perseguição a Murta e o assassinato de Mansinho:

“Amigo brasileiro - disse Pónce ao terminar - você me parece disposto a ten- tar mas fique sabendo que vai tentar uma loucura que pode terminar num cár- cere boliviano e que provavelmente termina é com a sua morte. Mas se quer vai.

-Quero - disse João - Algum brasileiro há de chegar a Bolívia.” (p. 142)

Obstinado por dar algum fim a sua história que não o de render-se ao governo ditatorial, cruzar a fronteira deixa de ser uma opção, para ser a única saída do grupo. Partem temerosos na lancha, conduzida por Joelmir, Aniceto, Geraldino, João e Laurinha.

Ocorre, então, o que desde o início do romance se insinua, a prisão e o assassinato dos revolucionários. Murta, mergulhado no rio Paraguai para esconder-se da polícia, vê a Faceira partindo e não hesita em querer salvar sua vida batendo no casco da lancha com determinação, enquanto os outros temem serem descobertos pelos policiais. A fatalidade esperada ocorre e o tiroteio nas águas do Paraguai causa morte de João e Geraldino e o desespero de Laurinha diante da inevitável tragédia. É o golpe final da derrocada das utopias:

"Foi João quem caiu primeiro. O segundo foi Geraldino. Sombras escuras escorregaram para dentro do rio protegidas pela súbita parada da metralhadora diante do aparecimento de Laurinha no tombadilho feito uma doi- 
da, no feixe de luz dos holofotes." (p. 156-157)

A estruturação narrativa até esse momento procura reproduzir as impressões e sensações dos personagens através da minimização dos monólogos e da sobreposição de discursos, os quais revelam a ausência de condições para a troca de experiências, para o aprendizado pessoal e coletivo e para o amadurecimento psicológico e histórico. Os traços paródicos e metalinguísticos concorrem para o questionamento da eficácia do realismo tradicional ao propor a representação literária de um universo definido pelo avanço tecnológico e pela violência dos regimes políticos. Esse questionamento irá desdobrar-se na própria caracterização de Gil: o livro que gostaria de escrever é um mero 'esboço', já que o material da narrativa, a Revolução, perdera-se no curso da História.

Bar Don Juan reverte as possibilidades apontadas por Quarup no que diz respeito à resistência contra o Estado opressor, reformulando a própria composição narrativa. O realismo tradicional teorizado e defendido por Lukács é reafirmado na medida em que Bar Don Juan aponta para a impossibilidade de a modernidade produzir obras de arte unas e coesas, pois o conceito de fragmentação impregna não apenas o universo dos personagens, mas, fundamentalmente, a estética romanesca.

Se Quarup caminha para a construção de um romance realista, Bar Don Juan aponta para as dificuldades de construir esse realismo pretendido em um contexto histórico caótico. É, porém, em Reflexos do Baile que Antônio Callado desconstrói até a raiz o romance realista, retomando-o, posteriormente, em Sempreviva, quando parece querer voltar à busca de uma expressão mais universal. 
As duas primeiras partes de Bar Don Juan encerram uma crítica a Quarup, às esquerdas e ao realismo, pois corrompe, ao mesmo tempo, a possibilidade de aprendizagem do homem, a da concretização de um projeto utópico coletivo e a da elaboração de um romance uno e coeso, que traga em si um retrato social, no contexto latino-americano.

Porém, inesperadamente, a terceira e última parte de Bar Don Juan procura reconstruir o 'romance da aprendizagem' numa perspectiva em tudo diferente da que se formou com a trajetória de Nando, já que essa trajetória, projetada na história de João, representou a sua derrota e a do grupo revolucionário.

Antônio Callado aponta para a urgência de realizar uma crítica à luta armada e repensar os caminhos da sonhada revolução brasileira. Para o leitor que esperava a derrocada definitiva da história das esquerdas, o romance projeta uma perspectiva utópica que suplanta o fracasso do movimento revolucionário e reforça, mais uma vez, a utopia matriarcal, já esboçada em Quarup na elaboração das personagens femininas.

A restrição do universo dos personagens nas duas primeiras partes é enfatizada pela ausência da participação em movimentos populares, os quais ocuparam o cenário político e econômico entre 1961 a 1964 com importantes lutas salariais e sociais, mas tão logo deu-se o golpe militar, as organizações legais foram extintas e a força dos sindicatos estraçalhada pela violência. ${ }^{1} \mathrm{O}$ silêncio imposto aos trabalhadores da cidade e do campo estendeu-se aos

\footnotetext{
1 “O golpe militar veio a representar a imediata destruição das mais importantes conquistas realizadas pelos trabalhadores. Significou o fim do direito de greve, das associações de camponeses e da estabilidade no emprego através das criação do FGTS; a anulação da Lei de Remessas de Lucros e da nacionalização das refinarias de sindicatos, prisões dos lideres sindicais, cassações de direitos políticos, enfim, sistematizava-se a repressão." (In: MENDONÇA, Sônia Regina de e FONTES, Virginia Maria. História do Brasil Recente. 1964 - 1992. 4 ed. revista e atualizada. São Paulo, Ática. 1996 - Série Princípios - p.p.19 e 20).
} 
quadros intelectuais e da classe média que pudessem significar algum tipo de oposição ao regime ditatorial. Os revolucionários comandados por João pertencem a classes sociais privilegiadas no contexto social brasileiro, e nas breves conversas que mantêm sobre os fins da revolução, não questionam quais seriam os interesses da população.

Forma-se um mundo paralelo e o povo é esquecido na sua miséria. Os marginalizados socialmente são também marginalizados nessa narrativa, pois contam com raríssimas aparições, todas inexpressivas para a condução do enredo. A insignificante participação da população na história ficcional faz com que vibre ao longo de todo o romance um profundo questionamento sobre o sentido da revolução.

Antônio Callado antevê o que aparecerá, anos mais tarde, na auto-crítica das esquerdas como sendo o problema central do fracassado movimento revolucionário. Distante da possibilidade de compreender os anseios populares, a esquerda debate-se por entre questões de caráter ideológico, perdendo de perspectiva as formas e cores verdadeiras da realidade, como nos alerta Fernando Gabeira, em $\mathbf{O}$ que é isso, companheiro? ${ }^{1}$ :

\begin{abstract}
“Alguns aspectos da experiência daquele grupo foram deformantes. O principal era a mistificação operária feita pelos intelectuais e estudantes de classe média. Pequenas organizações trotskitas, por exemplo, conquistavam um operário para as suas fileiras e ficavam impossíveis. Às vezes, ia toda a direção da organização visitar o seu 'operário'. Em muitos casos, divergências politicas terminavam com essa frase: vamos consultar nossas bases operárias. Nem sempre as bases operárias podiam somar mais do que cinco pessoas. Mas eram apresentadas na discussão como base e, às vezes, se saltava para uma abstração maior: setor operário. Um pouquinho de imaginação, um pouco de
\end{abstract}

${ }^{1}$ GABEIRA, Fernando. O que é isso companheiro?. 35 ed. Rio de Janeiro. Guanabara. 1988. 
discussão acalorada e o setor operário passava a ser 'os operários' ou mesmo ' o proletariado'. De repente, você era identificado com uma posição e garantiam que era uma posição antioperária, que não tinha apoio do proletariado.”

Espaço urbano e modernização acelerada, num país com graves problemas sociais como o Brasil, geram abismos entre os códigos culturais, aumentados pela opressão do Estado, já que a vida nas sombras torna-se condição para a sobrevivência de muitos dos homens da esquerda. O contato mínimo com a população impede qualquer ação transformadora e o poder ditatorial aproveita-se dessa situação para divulgar falsas informações e vender a imagem de um Brasil que se moderniza para sair da condição de país subdesenvolvido.

O universo dos primeiros capítulos de Quarup é resgatado pela conduta dos personagens de Bar Don Juan: não há um centro de convergência para o qual concorram os ideais e a procura desse centro passa por caminhos tão equivocados e tortuosos quanto os que a expedição passou na selva do Xingu. Se a expedição encontra um enorme formigueiro de saúvas gigantescas, os revolucionários encontram a morte e a loucura. Avançados os tempos históricos, os mecanismos repressivos tornam-se ainda mais violentos, surpreendendo até mesmo João, quando da sua terceira prisão com Laurinha. É esse imponderável terror que esteriliza os homens, engessandoos em uma condição brutalizada de vida, que os impede de se darem a oportunidade de se preocuparem com a sorte alheia.

O passado torna-se algo inapreensível e a urgência do presente impede que se formulem imagens a serem projetadas num futuro próximo. Os revolucionários, frequentadores assíduos do bar Don Juan, não discutem as 
ações nem antes nem depois de serem realizadas, elas se tornam meros acontecimentos que não trazem consequências maiores.

Em meio a tantas incertezas, João gesta uma nebulosa expectativa de ir à Bolívia para encontrar-se com o grupo de Che Guevara e articula o grupo para lá chegar. Porém, também diante dessa que seria sua cartada final, não socializa a reflexão de como conquistar tal objetivo e ignora as condições evidentemente desfavoráveis do momento histórico.

Ir à Bolívia torna-se muito mais uma questão de honra do que propriamente um passo importante para a revolução, pois é a única maneira de João sentir-se menos frustrado e, talvez, útil aos homens que admira profundamente. Ao descobrir que, há um ano atrás, quando ainda existiam esparsas organizações armadas em alguns pontos de Minas Gerais, Goiás e Mato Grosso, o homem que se apresentou a ele como Adolfo Mena era, na verdade, Che Guevara, João, ao mesmo tempo em que compreende o tempo perdido por entre as noitadas no Don Juan, deixando os revolucionários do interior do Brasil apodrecerem antes mesmo de amadurecerem e darem seus frutos, sente um lampejo de esperança e de orgulho por ter tido conversado com 'Che':

"João virou a cerveja sentindo no copo um cheiro de mato e de pólvora. Via-se perto do Comandante, agora que a figura no Mena fundira-se à sua. Via o encontro dos dois na selva boliviana com a certeza simples dos visionários.” (p. 142)

Com o assassinato de João, o foco narrativo converge para a figura de Laurinha, o que anuncia a redefinição dos caminhos interpretativos do 
romance, uma vez que a situação política do país passa a ser um mero pano de fundo para as crises pessoais da personagem.

Nasce, então, um herói e um outro tipo de romance sob o ponto de vista da Teoria do romance, de Georg Lukács, pois, com as sucessivas transformações por que passa Laurinha, será recuperada a perspectiva elaborada em Quarup, centrada na possibilidade de se transformar a História. Experiência e aprendizado são conceitos insondáveis até o momento em que Laurinha consegue rever os erros passados. A partir daí, a ex-companheira de João, depois de viver os limites da dor, passa a reciclar as experiências do grupo e o tempo vivido ganha as tintas de uma lição a ser aprendida.

Até a dissolução do grupo revolucionário, Laurinha diferentemente de João, que se caracteriza pela ação, mantém-se passiva em relação aos fatos vividos: esquiva-se das lutas e dos conflitos externos, minimizando quaisquer problemas que pudessem desestabilizar o seu mundo interior. É o que se vê quando, depois do estupro sofrido, enquanto João planeja o assassinato do policial, mas que Laurinha evita sequer comentar, não se dando à revolta, nem a indignação, desejando, apenas, o esquecimento.

Fechada em si mesma, como não é possível anular a violência vivida, Laurinha assume uma atitude contemplativa do mundo:

\footnotetext{
"Mesmo em noite de pouca luz, Laurinha, quando João chegava tarde, podia ficar horas contemplando, da janela do apartamento em que moravam, o jardim do alemão() Laurinha sentia na água parada, com sua coroa de sapos coaxantes, a tensa expectativa da manhã, quando seria rompida pelos corpos bronzeados das crianças, Amelinha e Karl” (p. 13)
} 
Em busca de um refúgio para a alma, Laurinha, para esquecer o violento mundo de João, procura um espaço em harmonia e equilíbrio, o qual, como vimos, rompe-se com a morte da menina Amelinha eletrocutada na piscina. A maneira como a família recebe a fatalidade, soterrando a piscina e trancando toda a casa, reforça em Laurinha a impossibilidade de desvincularse dos problemas inerentes à condição de, simplesmente, estar vivo. Porém, a personagem, não conseguindo lidar com suas frustrações, fecha os olhos e a alma para mais esses sinais do mundo e passa a procurar outros meios de se alienar dos problemas.

Amar um intelectual engajado na luta armada, responsável por um grupo guerrilheiro e por estabelecer os contatos entre cubanos e brasileiros, e desejar uma vida tranquila, num mundo idealizado, pleno de virtudes, longe da miséria e da violência, são as duas faces entre as quais Laurinha debate-se silenciosamente. Diante da situação irônica em que vive, a personagem, sem vislumbrar nenhuma saída possível, culpa João pelo estupro, uma vez que julga ter se envolvido no grupo revolucionário por causa dele, e culpa a revolução e Murta pelo assassinato do companheiro.

Trabalhando na floricultura de Maria, sua antiga conhecida, Laurinha evita pensar em Murta, a quem julga odiar por ter denunciado a Faceira, e na família de Mansinho, principalmente, em D. Adelaide, sua mãe, e Jacinto, seu romântico irmão. A necessidade de enterrar o passado faz com que a exrevolucionária deseje apenas viver o momento presente, sem qualquer perspectiva futura.

Mal suportando a dor da lembrança, Laurinha esforça-se por isolar-se do mundo e do seu próprio passado, usando como recurso os mecanismos antigos de fuga. Porém, eles já não funcionam, pois foram corrompidos pela 
ação das mortes de Amelinha e de João. As águas carregam imagens mórbidas e a narrativa passa a ser pontuada pelo simbolismo da terra. À emoção e sensibilidade, Laurinha procura responder com a razão e o egoísmo, e encontra no trabalho exaustivo com as flores e a terra, durante períodos inteiros, sem querer retornar à rotina de almoçar, jantar e dormir, a fuga necessária para que conseguisse sobreviver. Se antes a personagem isolava-se em longos devaneios a partir do quadro de aparente equilíbrio que a casa do vizinho representava, agora ela os evita, concentrando-se numa vida hiperativa.

$\mathrm{Na}$ lida as flores, como uma 'japonesa de plantação de café', Laurinha quer fundir-se ao mundo orgânico e desligar-se das leis e costumes dos homens. Nega a vida humana, como nega os revolucionários, já que não compreende os gestos de João, nem as causas e os pretensos efeitos da revolução que ele buscava, não encontra sentido na sua própria história de vida e nas outras tantas histórias que a rodeiam. Distante de encontrar o significado profundo da violenta realidade brasileira, Laurinha existe num hiato, o qual não consegue preencher seja com desejos pessoais, seja com utopias coletivas.

Laurinha desiste da busca de João, ainda que por um caminho tão barroco como o eram os 'balcões avarandados' da delegacia em que fora estuprada, de aprender e ensinar lições de companheirismo e de solidariedade em um mundo de verdades imperfeitas e de tragédias completas. A participação que Laurinha teve nos projetos revolucionários nada mais significou para ela do que uma maneira de provar a João o seu amor:

"Se tivesse coragem de puxar de novo o assunto em que ele nunca mais tocara, Laurinha lhe diria que de Salvador e da Polícia só lhe ficara a i- 
déia do sacrifício feito por ele e para ele, que se tivesse dito coragem, no dia da conversa, cada um em sua poltrona, teria falado, dramática e ver- dadeira: 'João, meu corpo já tem sua história de revolução para você e chega, chega, agora chega, olha as medalhas roxas que eu ganhei na lu- ta, as pancadas, os chupões, aquele bruto entrando em meu ventre seco. Me ensaboei no chuveiro, na banheira de água, lavei a baba, o cuspe, la- vei a revolução toda, e agora chega, chega. Não disse nada de você e de seus encontros, protegi você, menti por sua causa para você se orgulhar de mim e agora chega, pelo amor de Deus." (p.p. 48-49)

Tanto o regime autoritário surpreendeu o movimento revolucionário pela liberdade com que, aleatoriamente, aprisionava, torturava e matava pessoas, quem em Bar Don Juan, ao contrário de Quarup, amor e revolução não compõem uma unidade possível. Levindo influencia Francisca a participar dos movimentos sociais e ela, por sua vez, leva Nando a engajar-se na luta armada, o que expressa a comunhão existente entre a subjetividade dos personagens e a realidade. Essa integração não é mais viável em Bar Don Juan, já que tanto subjetividade quanto realidade estão estraçalhadas pelo poder opressor. João, ciente dessa cisão, lamenta a perda de Laurinha antes de entrar na Faceira e descobrir que ela iria acompanha-lo:

"Logo que desceram a rampa para a beira do rio João viu a Faceira no seu atracadouro e foi como se a lancha há muito o servisse e fosse sua amiga. A única tristeza que o assaltou foi a de partir assim, sem dizer adeus a Laurinha, deixando-a talvez perseguida, talvez presa, traindo Laurinha com a Faceira, confirmando quem sabe sua impressão de que uma escolha fora feita entre ela e a revolução, de que ele preferia tentar salvar o mundo a salvar-se vivendo com ela quando as duas coisas eram sementes gêmeas, germinando na mesma terra escura e fresca”. (p.p. 150-151) 
A visão martírica apresentada em Quarup é resgatada por João e por Eustáquio, o revolucionário cubano, que só concebem a transformação social através do sofrimento de muitos homens. A revolução, embora aponte para um horizonte utópico paradisíaco, em que o homem viveria em uma sociedade igualitária e justa, é uma árdua e dolorosa tarefa, que não comporta nem conflitos existenciais nem a felicidade individual.

Porém, se por um lado os revolucionários creem serem eles os mártires da revolução, por outro, abraçam a designação da 'esquerda festiva', cunhada pela maneira como tratavam a realidade nacional e como conduziam suas vidas, expressão que, segundo Zuenir Ventura, 'teria presença assegurada no léxico e no espectro ideológico da política nacional':

"'A esquerda festiva começou mesmo a ser realidade depois de 64' acredita o poeta Ferreira Gullar, um membro assumido do grupo. 'A esquerda recorreu então à festa como uma forma de se manter, de ir adiante, de não morrer, de resistir.",1

Ironicamente, martírio e 'festa' convivem na descrição das esquerdas e, sem se anularem, geram um profundo sentimento de culpa. As noites nas uísquerias não expressam uma maneira de 'resistência', como entende Ferreira Gullar na sua razão conciliadora, mas a fuga da responsabilidade histórica dos revolucionários.

É assim que João e Eustáquio se sentem ao se lembrarem das condições em que os companheiros vivem, fugindo da polícia ou tentando organizar os

\footnotetext{
${ }^{1}$ Idem, ibidem.
} 
focos revolucionários no interior do país. Também Nando, isolando-se na praia e vivendo de infindáveis prazeres sexuais, não consegue esquecer-se de Levindo, assassinado por defender as causas populares. O horizonte de sofrimento e abnegação por uma causa de nobre como a substituição do sistema capitalista pelo socialista nos países latino-americanos atormenta a consciência da 'esquerda festiva', que ainda entrevê, por entre os escombros e os mortos, uma perspectiva utópica salvacionista:

“(...)quando algum companheiro balançava a cabeça, dizendo que o Governo Militar era cada vez mais forte e a resistência cada vez mais desmembrada, que as perspectivas revolucionárias eram negras, João, com seu amor pela poesia espanhola, dizia: Aunque se de noche(...)" (p. 49)

A 'festa', enquanto um meio de fuga, é a expressão mais clara do medo dos homens diante da história latino-americana, tomada pela violência e pelo autoritarismo, e diante do esgarçamento das suas subjetividades num 'ossuário de naturezas mortas ${ }^{1}$. É o meio pelo qual os homens conseguem fugir da história nacional e das suas histórias pessoais, vivendo marginais à sociedade e a si mesmos.

Tal solução não serve, porém, aos homens que sentem desejarem valores verdadeiros para as suas vidas e, nessa medida, com um forte sentimento de culpa por não encontrarem em seus cotidianos esses valores, fazem quaisquer sacrifícios para alcança-los, crendo estarem, ironicamente, servindo à concretização de uma utopia coletiva. Nando parte para a luta

\footnotetext{
${ }^{1}$ LUKÁC, Georg. Op. Cit.
} 
armada com Manuel Tropeiro convicto de ter encontrado a sua missão na terra, a qual será em Bar Don Juan questionada pelas consequências trágicas dos caminhos tomados pelos revolucionários. $\mathrm{O}$ ex-padre seria, em Bar Don Juan, um dos que apodrecem no sertão à espera do aviso para darem início às manobras dos focos guerrilheiros.

O caráter martirizante da revolução, como queria João e Nando, não encontra eco em Laurinha, que só compreende a verdadeira dimensão do movimento revolucionário, como ela nos faz saber, no momento em que é estuprada por Salvador. O sofrimento e a dor, porém, não a fazem praticar alguma ação de revolta, e, sim, fazem com que ela enterre no seu universo interior, em silêncio, a utopia revolucionária.

Aterrorizada pela violência, percebe o quanto romantizava os companheiros e o quão distante o seu ideário utópico estava na realidade, desenvolvendo um olhar crítico sobre as ações de João, a quem outrora idealizara e a quem atribuíra a função de fazê-la feliz.

A personagem, ao visualizar a dimensão trágica da história em que estava envolvida, busca refúgio na sua subjetividade, já que, negar a perspectiva revolucionária tal qual se lhe apresentava significaria negar a sua utopia pessoal, uma vez que estaria negando João. O estupro marca a ruptura de Laurinha com o movimento contra a ditadura e, como o companheiro, sabe não ser possível a unidade entre amor e a revolução.

Laurinha evita martirizar-se e a postura passiva e contemplativa que a personagem assumira na primeira parte do livro é corrompida pela necessidade de substituir as lembranças e os pensamentos rancorosos. Porém, isso se torna impossível, pois um forte sentimento de compaixão 
começa a crescer em seu espírito depois de ela ter lido uma breve reportagem no jornal de que seriam enterrados os restos de Mansinho:

"Até agora mal havia pensado neles, ou em quem quer que fosse, drenada de qualquer piedade a partir do momento desesperado em que se abraçara na Faceira a João crivado de balas e em que tivera seu cadáver brutalmente arrancado dos braços. Não lhe sobrara nem piedade a sentir por si mesma quando foi presa, pela Polícia e pela Marinha, em Corumbá e Ladário (...) Preferia nunca mais enxergar ninguém que tivesse tido alguma coisa a ver com a lamentável história e sentia forças para cuspir na cara do Murta, caso jamais o revisse. Se ainda rezasse pediria honestamente a Deus que a morte do Murta tivesse sido severa e dura nas águas do rio Paraquai. Foi a lembrança de dona Adelaide que afinal levou Laurinha no dia seguinte à capela do Cemitério S. João Batista, onde pouca gente, muito pouca, cercava o ataúde fechado e coberto de flores" (p.p 174 - 175)

A partir desse momento, a vida de Laurinha ganha rumos inesperados e o romance passa a acompanhar os acontecimentos inusitados da sua vida. Sensibilizada pela compaixão, a protagonista recebe Jacinto e um seu amigo, João Batista, na floricultura, e vê que ambos continuavam a acreditar e a trabalhar pela revolução com o mesmo romantismo e ingenuidade dos seus antigos companheiros. Jacinto e Batista queriam pedir a Laurinha que se engajasse novamente no movimento.

Embora Laurinha tenha repudiado qualquer ajuda, é esse encontro que irá despertar nela a necessidade de reencontrar-se com o seu passado, num "desejo de vida crua e sacrílega, de sentir-se realmente perto de João, punindo João pela ausência". Para acalmar a memória insistente, a 
protagonista informa-se sobre Salvador - e descobre que ele morrera - e vai até a antiga casa do alemão na esperança de recuperar, através da beleza daquele jardim, o silêncio das suas inquietações, acordadas pela visita de Batista e Jacinto.

Porém, sua expectativa é frustrada ao perceber que aquele espaço em que homem e meio encontravam-se em completa harmonia estava abrigando um centro de recuperação para excepcionais:

"Laurinha fechou os olhos e apertou os ferros do portão com violência pensando, possessa da sua ideia, que aceitaria ir dali para o inferno se a terra diante dela se rachasse e engolfasse para sempre aquele terrível circo e de novo emergissem o gramado, as plantas, a piscina, as crianças da caas e a música triunfal" (p. 183)

As crianças excepcionais brincando no jardim causam-lhe verdadeira repugnância e o desgosto que a protagonista sente de início transforma-se em desespero. O espaço visto por Laurinha como 'deformado' e 'terrível' desestrutura o frágil universo em que tentara se isolar, impedindo que mais uma vez ela buscasse fugir de seus problemas pela construção de imagens aparentemente perfeitas.

A inversão brusca de imagens reforça no imaginário de Laurinha a impossibilidade de ela encontrar a realidade que por tantos anos fantasiara existir. Ao contrário de João, tal trajetória caracteriza o que Lukács classifica como 'romantismo da desilusão', uma vez que a alma da personagem é 'mais ampla e mais vasta do que todos os destinos que a vida lhe pode oferecer':

\footnotetext{
${ }^{1}$ LUKÁCS, Georg. Op. cit (p.p. 129-154)
} 
“A diferença estrutural decisiva que daí resulta é que já se não trata aqui de um a priori abstrato em face da vida, que pretenda realizar-se por actos e cujos conflitos com o mundo exterior forneçam ao romance a sua efabulação, mas antes de uma realidade puramente interior mais ou menos acabada e rica em conteúdos que entra em concorrência com a do exterior, e que possui em si própria uma vida rica e movimentada, e se considera, na sua espontânea confiança em si mesma, como única verdadeira realidade, como a própria essência do mundo, constituindo o seu fracasso na tentativa de tornar efectiva essa adequação, o objeto mesmo da narrativa.” (p. 129)

Laurinha resgata uma das fases da deseducação de Nando e percorre um caminho muito semelhante ao seu, uma vez que as experiências lhe mostram os equívocos da sua própria postura perante a realidade, obrigando-a, como ocorreu com o herói Quarup, a transformar a sua relação com o mundo em função das condições objetivas impostas pelo contexto histórico.

As alterações simbólicas que a casa representa para Laurinha estende-se ao plano narrativo que irá desdobrar as recorrentes imagens relacionadas à água e à terra em significados positivos e vitais. Vencendo a aversão inicial às crianças excepcionais, a protagonista, a pedidos insistentes da Matilde, a administradora da casa, ajuda a encontrar e a recuperar a piscina que fora soterrada depois da morte de Amelinha.

O envolvimento de Laurinha com as crianças desperta nela o sentimento de solidariedade há tanto tempo evitado pelo temor de novamente sofrer por causa do egoísmo e da terrível violência cultivados com esmero nas terrar brasileiras. Reconhecendo persistir, apesar da brutalização da sociedade, gestos generosos, que procuravam incluir os marginalizados num projeto utópico nacional, Laurinha sente estar redescobrindo um antigo amor pela 
humanidade, acompanhado, naturalmente, de uma intensa alegria de viver que ameaçava ressurgir:

\begin{abstract}
"Sentindo um vago mal-estar de traição indefinida diante da alegria que medrava dentro dela feito um tufo de planta num penedo, Laurinha voltou várias vezes para orientar o trabalho de recuperação, de exumação da piscina. Com pás de brinquedo as crianças ajudavam e atrapalhavam os operários, pequenos arqueólogos de uma raça enferma procurando na terra algum perdido segredo de saúde. Quando atrapalhavam demais, Laurinha lhes mostrava como podiam tirar terra mais longe e um dia riu da verdade, riu de prazer e gosto quando um dos meninos, com grande alarido, convocou todos a contemplar a sua descoberta: era o sapo bronze que esguichava água para dentro da piscina.”(p. 209)
\end{abstract}

A terra e a água, associadas à vida e à fecundidade, ao elemento criador, que abrigam não mais a morte de Amelinha e de João, mas a esperança das crianças, renova a cadeia de significados do romance. Reverter a simbologia da terra e da água é recriar a relação de Laurinha com o mundo, o que o autor cumpre reinventando o imaginário utópico das esquerdas, corrompido pelas decepções e fracassos do movimento revolucionário.

Como em Quarup, a revolução precisa construir bases novas ainda não inventadas, porque, para inventá-las é necessário que os homens mergulhem em si mesmos. Reinventar a revolução é reinventar os homens, reinventar a relação que mantêm com o mundo, é reconstruir o olhar sobre a vida. Nando sofre uma deseducação completa para projetar um novo Brasil e Jacinto e João Batista, os discípulos do ex-companheiro de Laurinha, conseguem perceber, antes mesmo dela, a necessidade de forjar novas imagens do Brasil revolucionário a partir da experiência histórica: 
“João Batista se ajoelhou aos pés de Laurinha e falou em voz baixa e comovida: (...) Só depois que a gente vence é que as coisas se revelam como são e as coisas que passaram por ser comédia e besteira se justificam. Ante não dá. Não dá para a gente bolar o desenho, sabe como é? Eu tenho um colega que foi aluno do João e me disse que o João no livro dele chegou mais perto que qualquer um do desenho que serve para a gente. O livro está pronto? Me dá que eu tenho quem publique, aqui e em Bueno Aires.

(...)Jacinto sorriu e continuou:

- No duro, no duro, Laurinha, você devia engrenar com a gente. O desenho está saindo. Vai sair. Juro" (p.p 180-181)

A compreensão do esforço daqueles jovens que Laurinha julgava serem ingênuos e românticos dá-se somente depois de ela ver ressurgir a piscina. A reciclagem das águas figuratiza, pois, a reciclagem do seu próprio mundo interior.

No dia da inauguração da piscina, a protagonista reluta contra o desejo de juntar-se às crianças, porém, diante da insistência de Matilde, aceita o convite e abre-se para receber o amor daqueles que a julgavam ser a 'ligação com o ser subterrâneo' e que, por isso, lhes traria a possibilidade de conquistarem um pouco mais de vida.

Narrada brevemente, a inauguração da piscina encerra as profundas transformações do universo interior de Laurinha, iniciada no dia em que revira a casa pela primeira vez depois da morte de Amelinha e de João. Embora a protagonista desejasse recuperar as imagens românticas da antiga piscina, soterradas pela morte da menina, não encontra meios para tanto, pois as imperfeições das crianças lhe causam repulsa, o que denuncia a impossibilidade de, novamente, mascarar a realidade. 
Diante da necessidade de ter que ligar com o mundo tal qual ele se apresenta, Laurinha reconhece o amor nesse universo degradado física e moralmente, ainda que pressinta um profundo sentimento de compaixão ao ver 'as águas renascidas, as águas lustrais, as águas (...), que muito tinham penado no exílio da terra', agora passarem 'a águas que iam operar os milagres que Matilde não sabia fazer sozinha: de água de júbilo a águas de amor'.

Num processo de identificação com essas águas, Laurinha rasga sua interioridade, desafogando rios de lágrimas, para dar e receber amor das crianças. Temendo ceder à pressão violenta da vida, como as águas piscina cederam à terra, vindo a auto-exilar-se na própria terra natal e a resignar-se a um trabalhoh movido pela compaixão, Laurinha nega a possibilidade de permanecer na casa para ajudar Matilde.

O espelhamento da protagonista nas águas denuncia o empobrecimento da força vital dos homens, os quais acabam por sucumbir à violência do opressor, passando a se esconderem nos subterfúgios da realidade, para, de alguma forma, manterem-se vivos, ainda que doentes. Entendendo que as águas deixaram de cumprir sua função primordial para servirem de meio terapêutico às crianças, Laurinha sabe da necessidade de dar continuidade ao que João começara e de auxiliar no árduo trabalho de construir e preservar a memória histórica nacional, a fim de que o presente não traísse nem o passado nem o futuro:

“-Você precisa ficar conosco, meu anjo - disse Matilde. Laurinha sorriu, naquele momento de reconciliação, mas a si mesma, com doçura, uma astuta doçura, disse que não, que não ia tombar na cilada da piedade. Acabara de encontrar o caminho de sua vida, o único, o caminho que a levava 
de volta a João. Não podia cair na armadilha da compaixão. No mundo são muito mais numerosos os sãos, e sua tarefa, a tarefa de João, era salvar os são, para que morressem com saúde.” (p. 211)

A revolução interior por que passa Laurinha faz com que ela descubra o seu eixo, recuperando o sentido profundo da vida e, portanto, o da revolução. A protagonista consolida a unidade entre amor e revolução, entre intimidade e realidade, o que a impulsiona a forjar uma perspectiva utópica diferente à de João.

Desenvolvendo a trajetória do herói do 'romance da aprendizagem', Laurinha desprende-se do caráter rígido que construíra para evitar possíveis frustrações e fracassos e reorganiza seu olhar sobre o mundo. É nesse momento que a protagonista entende a morte ${ }^{2}$ como elemento gerador da vida e não mais como o fỉm inevitável das coisas, dos seres e das ideias. O universo metodicamente construído de Laurinha para esconder a morte é destruído no momento em que ela a aceita como condição para a vida, adquirindo, numa leitura marxista, um olhar dialético sobre a história.

Das ruínas à afirmação do desejo de mudança, a protagonista nega o que seria o fracasso fundamental - a aceitação da insolubilidade dos problemas brasileiros - e rejeita a técnica básica da frustração - o adiamento das expectativas - para, aceitando a morte e vivendo o amor, alargar as

\footnotetext{
${ }^{1}$ LUKÁCS, Georg. Op. Cit.

${ }^{2}$ A força do Eros, segundo Hebert Marcuse, numa sociedade utópica, absorveria a valoração negativa da morte: "Numa civilização repressiva, a própria morte torna-se um instrumento de repressão. Quer a morte seja temida como uma constante ameaça ou glorificada como supremo sacrifício ou, ainda, aceita como uma fatalidade, a educação para o consentimento da morte introduz um elemento de abdicação na vida, desde o princípio - abdicação e submissão. Sufoca os esforços 'utópicos'.” (In: MARCUSE, Hebert. Eros e civilização. Uma interpretação 'filosófica do pensamento de Freud. 3 ed. Rio de Janeiro. Zahar, 1968 - p 203 ). Laurinha, ao desvencilhar-se do universo de João, também reelabora a visão de morte, pois abandona os sentimentos de 'abdicação e submissão' e inicia uma luta pela vida.
} 
possibilidades utópicas da construção da felicidade, fosse ela individual ou social.

A piscina torna-se a alegoria central da narrativa, uma vez que busca resgatar um momento morto, permeado pela ideia de fim - o eletrocutamento da Amelinha e o aniquilamento do espaço utópico da Laurinha - ao mesmo tempo em que traz um horizonte redentor, o qual desperta na protagonista o desejo de libertar-se do inferno de João, para construir uma nova perspectiva utópica:

“A música apenas começava quando Laurinha, antes que voltasse Matilde e que as crianças se fatigassem do banho de estréia, saiu quieta, pelo lado da garagem, andando no rupo do seu edifício. De rosto enxuto e passo firme. À medidade que avançava para o edifício despedia-se de uma Laurinha antiga, Que ela em breve não entenderia mais. O zelador, sorridente e compungido ao mesmo tempo, veio cumprimenta-la, vagamente dando-lhe pêsames e desejando boas-vindas. Dentro do apartamento foi direto à janela e abriu-a de par em par, segura não tanto da vista das crianças suas amigas como da paz reencontrada.” (p.p 211-212)

Vida e morte, amor e revolução, terminaram por compor o aprendizado de Laurinha. Tal aprendizado, porém, difere do de proposto em Quarup, pois, se Nando aposta no embate direto e violento contra o regime, Laurinha sabe estar absolutamente obstruído esse caminho e crê na possibilidade de arquitetar subterfúgios que levem os homens a resgatarem, apesar da violência irascível do Estado, a comunicação e a solidariedade entre si.

Essa seria a verdadeira revolução, pois que ela começaria na subjetividade dos brasileiros e se estenderia ao comportamento social, humanizando as 
relações entre as pessoas e, consequentemente, construindo uma sociedade justa.

Por isso, Bar Don Juan, além de apontar para o fracasso da luta armada e para o esfacelamento do ideário utópico das esquerdas, propõe, a partir de um olhar dialético sobre a história, a construção da memória dos comunistas e o uso dessa memória enquanto meio de superar os equívocos passados para projetar a imagem de um Brasil viável.

O modelo proposto neste romance concretiza a utopia matriarcal presente nos quatro romances estudados- direta ou indiretamente, como vimos em Quarup. Essa utopia revaloriza o amor e a fraternidade, porque supera a repressão sexual e a propriedade privada, próprias às sociedades patriarcais ${ }^{1}$. Antônio Callado, ao eleger a utopia matriarcal como o horizonte viável para a construção de uma nova sociedade brasileira, capta os anseios de algumas das vanguardas revolucionárias da época. Essas encontraram ressonância no mundo quando, contaminadas pelas idéias formuladas a partir da revolução sexual, desejavam abolir aspectos fortemente marcados pelo universo masculino para abraçarem outros definidos pelo universo feminino Isso significaria dizer que, afim de acabar com as violentas relações entre opressores e oprimidos, os homens teriam de passar por uma profunda revolução interior, para só depois, conquistarem a desejada igualdade social.

\footnotetext{
${ }^{1}$ Hebert Marcuse trata da construção de uma utopia mais feminina, a qual traria em si profundas mudanças nas relações entre Eros e o Instinto de morte, entre sexualidade e os valores sociais, e, fundamentalmente, entre o homem e o trabalho. Com essas mudanças, a morte deixaria de atraiçoar a 'promessa de utopia', o que resultaria em uma civilização sem repressão, e, consequentemente, sem os imensos contingentes de miseráveis que a história tem gerado: "A morte pode tornar-se um símbolo de liberdade. A necessidade de morte não refuta a possibilidade de libertação final. Tal como as outras necessidades - pode-se tornar também racional, indolor. Os homens podem morrer sem angústia se souberem que o que eles amam está protegido contra a miséria e o esquecimento. Após uma vida bem cumprida, podem chamar a si a incumbência da morte - num momento de sua própria escolha. Mas até o advento supremo da liberdade não pode redimir aqueles que morrem em dor. É a recordação deles e a culpa acumulada da humanidade contra as suas vitimas que obscurecem as perspectivas de uma civilização sem repressão." (Idem, ibidem. - p.204)
} 
Callado, perspicaz observador e voraz leitor, constrói os conflitos dos personagens não apenas em torno dos desastres da esquerda, mas daquilo que se mexe por debaixo de todos os escombros da história. Nas entrelinhas de Bar Don Juan, o autor propõe a revisão das propostas comunistas a partir da necessidade de uma reconciliação final entre os homens, exploradores e explorados, e entre eles e o mundo moderno, harmonizando a luta de classes, porque a briga da humanidade não é só por pão, é também por sonho, por beleza, por liberdade.

As mulheres de Quarup fundam esse horizonte utópico, mas, gestando a revolução sexual, não conseguem ainda ocupar o plano principal dos fatos. É Laurinha quem tem a oportunidade de protagonizar mudanças nos rumos da revolução, o que faz ao optar por zelar pela memória histórica do grupo revolucionário construída pelo exemplo de vida dos amigos. O livro de João é a materialização desse desejo que se desdobra na conquista de uma visão dialética dos processos históricos.

Mariana, tendo decidido fugir com Gil para o Chapadão, local esquecido pelos órgãos da repressão, também não consegue ignorar o passado e chama a atenção de seu companheiro e de Aniceto e Da Glória, que passam a morar com o casal, para a necessidade de voltar ao Rio de Janeiro a fim de juntar os cacos do movimento revolucionário. Gil, porém, convencido do fracasso do grupo, desiste da viagem no último momento, indo buscar material para o seu mais novo romance sem deixar de prometer a Mariana que iria juntar-se a ela, e mais o seu filho carregado no ventre, dali alguns meses.

A companheira de Gil, mesmo grávida, repete o gesto de Laurinha, pois torna-se a protagonista da ação narrativa, quando decide partir, levando consigo Aniceto e Da Glória. Usando o grupo de Luciano, um explorador 
das águas brasileiras, que trabalhava no projeto de interligar as Bacias do Amazonas e do Prata, Mariana, Aniceto e Da Glória embarcam sem serem reconhecidos, aterrorizados, porém, pelos retratos colados à parede do aeroporto, os quais traziam as feições torturadas dos revolucionários 'faturados' pela repressão.

O alívio por não serem reconhecidos dura pouco mais de alguns minutos, quando Mariana e Da Glória veem Aniceto com uma zagaia, conseguida com o grupo de Luciano, ir em direção à cabine do comandante do voo, e sentem que 'o avião descrevia no céu um círculo tranquilo e tomava o rumo do Norte, a direção da ilha de Cuba".

A determinação de Aniceto e a reconstrução do papel de Laurinha na narrativa gera a expectativa de que ainda é possível fazer algo pelo Brasil, desde que as pessoas encontrassem uma maneira de sobreviver às monstruosidade praticadas pelo regime. Porém, a tragédia nacional já se cumprira, anunciando os anos negros que ainda viriam. Reflexos do Baile busca recompor esse futuro e plasmar o homem que se via arrastar para o vazio, a morte, sofrível e indigna. 
3. A derrocada das utopias: Reflexos do baile,

a implosão do texto literário

"A história pessoal começa, se desenvolve e desaparece e parece não deixar consequência nenhuma. Neste sentido, poderíamos dizer que a nossa época vive uma ausência de futuro, por mais que se fale no futuro. Não há mais uma perspectiva de continuidade para além de certos fatos importantes ou para além das vidas individuais." (Ernildo Stein, em Orfãos de Utopia. A melancolia da Esquerda) 
Antônio Callado constrói o romance Reflexos do Baile por meio de cartas, páginas de diários e relatórios, dos quais não são dados ao leitor conhecer quem seriam os emissores das mensagens, mas, apenas, os destinatários. O autor deixa-nos, portanto, a tarefa de decifrar as especificações da linguagem de cada personagem, bem como a de interpretar os diversos perfis psicológicos, a fim de que, através da identificação de repertórios comuns, torne-se possível apreender quem são os interlocutores e quais as relações que mantêm com o conflito central da narrativa, o sequestro do embaixador norte-americano pelos revolucionários.

Por entre os papéis em avulso que dançam aos olhos do leitor, em princípio, sem nenhuma lógica, apresentam-se os fragmentos de uma história, que só irá adquirir sentido e coerência ao final da narrativa, quando for possível montar uma leitura que coloque ordem ao caos narrativo. Essa montagem contraria a liberdade que a narrativa parece propor - uma vez que não impõe ao leitor uma estrutura lógica rígida -, pois possui apenas um encaixe, o que frustra o receptor e denuncia a aparente imparcialidade e neutralidade do autor ( ou, pelo menos, da pessoa que se encarrega da disposição dos textos, da tradução das cartas escritas em inglês, ou até mesmo da organização das notas de rodapé).

A organização dos aspectos espaciais e temporais em Quarup e em Bar Don Juan - ainda que muitas vezes precária, principalmente no segundo romance, quando o autor perverte os motivos do primeiro - torna-se um referencial importante para a compreensão dos significados que se engendram em Reflexos do Baile, uma vez que esse romance contraria os imaginários utópicos construídos naqueles, ao mesmo tempo em que 
questiona a própria condição de a linguagem submeter-se à lógica de uma certa tendência para a estética realista.

Dessa maneira, lê-se, em Reflexos do Baile, a total implosão do realismo histórico - descrito por Lukács - e a construção de uma linguagem experimental e inovadora: cada capítulo do livro corresponde ou a um bilhete, ou a uma carta, ou mesmo a uma página de diário, e a soma de algumas dessas mensagens, agrupadas em uma certa ordem cronológica, compõe as três partes da narrativa: 'A véspera', 'A noite sem trevas' e 'O dia da ressaca'.

O narrador acaba, então, por destituir-se da função de centro de convergência da narrativa, seja pela dificuldade que tem de propor uma interpretação lógica da realidade, seja pela objetividade que pretende forjar ${ }^{1}$. A trama ficcional deve ser, portanto, lentamente, decifrada pelo leitor.

Embora haja momentos em que Quarup e Bar Don Juan também pareçam corromper a estética realista, perpassa pelo tom geral de ambas as narrativas uma constante preocupação do autor com que os desdobramentos dos acontecimentos e dos discursos sejam compreendidos pelo leitor e imediatamente associados à realidade brasileira. Preocupado com a situação nacional, Antônio Callado procura garantir nesses romances uma comunicação eficiente para fazer com que o leitor vislumbre o sentido que paira sobre os eventos narrados e compreenda as relações entre as suas causas e as suas consequências. Como intelectual engajado que é, Callado

\footnotetext{
${ }^{1}$ A opção de Antônio Callado pela construção de uma estética experimental coloca-o ao lado de outros escritores que, posteriormente, resgataram o período da ditadura ( em especial, o pós-Ato Institucional número 5). Os romances que se referem a tais episódios históricos identificam-se em torno da impossibilidade de propor uma lógica para a compreensão do caos nacional. A fragmentação social torna-se, então, o motivo da fragmentação estética.

Esse tema já foi amplamente estudado. Ver. Arrigucci Jr. Davi “O baile das trevas e das águas.” Achados e perdidos. São Paulo. Polis, 1979. e MACHADO, Janete Gaspar. Os romances brasileiros nos anos 70: fragmentação social e estética. Florianópolis, Editora da UFSC, 1981.
} 
deseja traduzir de maneira clara a sua visão do Brasil e propor, através de uma crítica aguda à esquerda, caminhos para a construção de um novo projeto utópico.

Em Reflexos do Baile, porém, a estrutura descentralizadora da narrativa provoca o distanciamento entre o narrador e a matéria narrada, e entre o leitor e o romance, o que revela as contrariedades do autor diante da matéria narrada. Essa contrariedade traz à tona a sua necessidade imperiosa de registrar um dos mais violentos e terríveis episódios da história nacional, ainda que pouco ou quase nada fosse possível compreender do destino que se construía para os brasileiros ${ }^{1}$.

Quebrada a coluna vertebral das relações sociais e degradada a ética e os valores morais, Antônio Callado não consegue inventar uma ordem para o caos dos anos que sucedem o Ato Institucional de número 5 e, por isso, traduz a realidade que consegue enxergar por entre a censura e a dor dos homens.

A fragmentação das categorias narrativas mimetiza, portanto, o mergulho do autor em seu presente histórico. Callado procura, no 'calor da hora', revelar o agonizante processo pelo qual passava a esquerda: as últimas ações armadas não tinham mais a perspectiva de transformar a trágica história nacional, mas tão somente a frágil esperança de recuperar os cacos que

\footnotetext{
${ }^{1}$ Há uma entrevista que Antônio Callado concede a Lígia Chiappini bastante esclarecedora sobre a estética dos seus romances, na qual se pode ler as seguintes palavras do autor: "Há uma diferença entre a confiança que você tem na sua capacidade de organizar o mundo na sua cabeça, pelo menos de uma forma compreensível, é o momento em que você começa a ver uma sucessão de acontecimentos nos quais passou a faltar, de sua parte, uma esperança de organiza-los e, deles próprios, uma falta de coesão, uma falta de sentido que eu acho que não é só no Brasil, não, mas que aqui aparece mais. É a perda da dimensão utópica no mundo contemporâneo, falta de uma religiosidade. Muita gente achou complicado Reflexos do Baile. Complicada é a realidade brasileira, que foge a qualquer capacidade de análise. O meu livro simplesmente reflete esse beco sem saída em que estamos e de que não sabemos quando vamos sair." (In: LEITE, Lígia Chiappini Moraes. Antônio Callado. Seleção de textos, notas, estudos biográfico, histórico e crítico por Lígia Chiappini Moraes Leite. 2 ed. São Paulo, Nova Cultura, 1988/ Literatura Comentada).
} 
sobraram da já antiga utopia, libertando alguns dos muitos companheiros presos.

Logo após efetivado o sequestro do embaixador, Clay, Amália envia um bilhete a Dirceu, no qual revela o seu incontrolável temor de ser presa ou assassinada, como o foi o chefe da ação revolucionária, Beto, e o desejo, único, de pôr fim àquele episódio o mais rápido possível, sem esperar qualquer outra coisa do futuro a não ser a libertação de alguns companheiros e a sua posterior e inevitável clandestinidade:

"Dirceu. Pelo amor que você tem à sua velha, confirma pelo portador noticia do embarque dos companheiros. Tem coisa de meia hora mas ainda estou de queixo chocalhando a gente viu pela bandeira da porta um cara que batia, pinta de careta insuspeito, vendedor de enceradeira ou enciclopédia, gravata e colarinho, pasta debaixo do braço. Num quarto o Válter guardando o Clay, pistola em punho, na sala vizinha o Vitor de olho no Rufino, que anda calmo, exausto ainda da caganeira épica, carregando de um lado para o outro, feito uma boneca de penas, seu dodó empalhado. Mandamos a Joselina à porta, para dizer que o patrão não estava. Mas o tal babaca engrossou, enfiou-lhe na mão um envelope, falando em voz alta, irritada, e só se ouviu de repente o pé de vento, o simum, até pensei, antes fosse, que o raio do pássaro tinha saído voando. Era Rufino invadindo a sala diante do Vitor apanhado de surpresa, besteirão, invadindo a sala de dedo em riste e a berrar Out! Out! e Her Majesty e não sei o que lá. Arrancou da mão da empregada o envelope, que rasgou em pedaços, e jogou na cara do outro, que emputeceu de vez: Agora é a polícia. É a Polícia! O cara era oficial de justiça, em visita de ex trema-unção. Estamos ameaçados de despejo, Dirceu!” (p. 104) 
Reflexos do Baile dialoga com falência, inegável, das utopias, causada pelo violento poder dos militares, o que obriga o leitor a compreender a obra menos através dos fatos que são narrados e mais através da maneira pela qual são narrados, uma vez que os homens transformaram-se em peças de um jogo infernal, no qual só se mantém vivo aquele que conseguir prever o próximo movimento do inimigo.

O narrador, nessa medida, se não organiza os discursos, tampouco os filtra. Sua preocupação é multiplica-los e diferenciá-los não tanto pelos conteúdos das mensagens, mas, fundamentalmente, pelas entonações dramáticas próprias a cada um dos tipos apresentados: policiais, embaixadores e revolucionários.

As nuances de cada discurso são ressaltadas e os sotaques ampliam o significado das palavras, as quais, ao mesmo tempo em que refletem a experiência pessoalíssima dos personagens, revelam as paixões, os ódios, a miséria e a futilidade de toda uma galeria de tipos comuns. É o que se lê, por exemplo, logo na primeira página do livro, quando Antonio Carvalhaes, o embaixador de Portugal, escreve uma carta a seu filho relatando o que, a partir do seu universo pessoal, seriam as terríveis mazelas da sociedade brasileira:

"Meu filho: O sequestro do nosso respeitável colega, o Embaixador da Alemanha, aglutinou os demais chefes de missão diplomática: jantam-se, almoçam-se, os mais americanizados recebem-se até para o breakfast, costume que me infunde um sacro terror (...) A tal degradação, prometo-te, jamais serei submetido, mas cedi anteontem à fraqueza de comparecer a um nervoso jantar, jurando a mim mesmo retirar-me logo após o café (...) Aflitos, debatiam-se os embaixadores entre a ambição de verem a si atribuídos tantos guardas quanto os colegas que mais os tenham, e o aborrecimento de 
não poderem sequer visitar sozinhos uma praia, ou a serra, oscilantes entre o malsão desejo de fazerem crer que seu sequestro é iminente e o calafrio de imaginar que talvez assim seja (...) Um deles, bochechas rubras e glabras, temia pelos sustos da mãe, na Europa, e jurava que nem em Saigon sentirase desamparado como cá ( p.15)

A entonação e o sotaque das cartas que Carvalhaes envia ao filho em Portugal configuram o perfil dos embaixadores, o qual se define por entre o cultivo de paixões levianas e ideias frívolas, marcando um comportamento essencialmente burocrático.

A construção dos discursos dos diplomatas é pontuada pela emissão de meias palavras, frases não concluídas, afirmações escorregadias, sobre todos os últimos acontecimentos. Não se sabe se as hesitações são para esconder a culpa que os diplomatas sentiam ao terem se tornado cúmplices das atrocidades praticadas pelo governo brasileiro, ou se para revelar o profundo desconhecimento do Brasil, fruto da impossibilidade de eles se identificarem com a cultura dos colonizados. Esses discursos combinam com os outros tantos discurso proferidos pelos policiais e pelos revolucionários, uma vez que as mensagens escritas, carregadas de pistas falsas e de palavras inusitadas, apresentam-se em linguagem cifrada.

Esses obscuros discursos que se desdobram ao longo da narrativa concorrem para reelaborar uma dinâmica já trabalhada em Quarup e em Bar Don Juan, em relação existente entre os dramas sociais e os pessoais, entre a individualidade e a coletividade, uma vez que a maneira pela qual se expressam os personagens traduz as contradições entre a condição em que vivem os desejos que possuem. 
Juliana é um exemplo bastante ilustrativo das relações problemáticas entre subjetividade e a realidade existentes no grupo dos revolucionários. Apaixonada por Beto, a filha do embaixador Rufino é peça fundamental no plano e na execução do sequestro do embaixador Clay, pois volta, depois de três anos, para a casa paterna apenas para conquistar a confiança dos diplomatas e possibilitar a retirada pacífica do norte-americano do baile.

Sem se questionar em nenhum momento sobre a legitimidade das suas ações, Juliana, menos para contestar o regime militar brasileiro e mais por amor ao namorado, Beto, trai seu pai e sua classe social:

“Dirceu: Nós queríamos quatro embaixadores, seis, quantos houvesse, mas nunca, juntos, ao mesmo tempo, o cara pálida e o embaixador inglês que arranjamos a partir do momento em que a companheira exemplar entrou toda de branco com seu sequestrado atônito e encarou o pai boquiaberto (...) Quando entrou a Juliana deve ter reconhecido de estalo, sentido nos confins da alma naquele momento, contra esta porta da sala que estou fitando agora, que ia virando, na hora, sem apelação, outra pessoa para o pai, outra para o Clay, e o bacana é que não abriu a boca, não explicou nada, não falou porra nenhuma, quieta e íntegra, compacta e luminosa, lâmpada apenas velada pelo vestido de baile. E olha que era quase da gente ver, quase da gente esmigalhar nas palmas da mão, feito mosquito, os remorsos e frescuras que voavam pela sala, um enxame deles rodeando Juliana, chamuscando asa, mas sem conseguir pousar nela, mariposas de merda cercando a lâmpada acesa, ardente.” (p.100)

Aliada ao grupo de conspiradores, Juliana não tem conflitos, especificamente, com a ação revolucionária da esquerda - como vimos acontecer com nando ou João - porque o seu envolvimento com a causa é de ordem estritamente pessoal ( é o que os companheiros percebem e 
temem: "Invariavelmente me preocupa a companheira Juliana quando escasseiam notícias do Beto. Até que ponto não passa a constituir um certo risco?, p. 54) . Para Juliana, as consequências das suas ações na realidade interessam na medida em que interessam a Beto e não à população brasileira, como era de se esperar.

Ainda que Nando também tenha engajado-se à esquerda, num primeiro momento, para ficar próximo à Francisca, ele consegue desprender-se dos seus desejos pessoais para doar-se às causas sociais, ávido por conhecer a si mesmo e aos homens e por conhecer profundamente o Brasil. Nando interioriza suas experiências e promove, antes de tudo, sua revolução interior para, então, engajar-se na luta armada. Até mesmo Laurinha, depois da morte de João, pôde conquistar um tempo e um espaço que lhe permitissem desprender o universo interior do exterior, para, aí sim, conquistar uma ação efetiva, e consciente, no mundo.

Juliana não desfruta dessas possibilidades, pois já não há mais tempo e nem condições para que realize um mergulho em si e na realidade brasileira, uma vez que o fechamento do regime ditatorial impede os homens de envolverem -se verdadeiramente uns com os outros e com as histórias, pessoal e nacional

O amor que a filha do embaixador alimenta pelo revolucionário leva-a a agir sobre o real, mas não lhe traz a oportunidade de lidar com as intenções primeiras do processo revolucionário da esquerda e nem de construir uma consciência crítica sobre esse processo, sobre o Brasil e sobre si mesma. Juliana trai sua história pessoal, sua identidade, mas não se sente, como os outros companheiros temiam, culpada ou arrependida. Ao contrário, sentese perdida e frustrada, com todos os revolucionários. 
A personagem cola, cegamente, uma máscara em tudo diferente daquela que a sua história da vida lhe forjara e desempenha com grandeza, o papel que lhe foi atribuído pelos guerrilheiros. Isso tudo, porém, não a fez descobrir o sentido das suas ações e das do amante, que acreditava, num futuro próximo, fazer da nação brasileira sua mulher amada:

"Beto: Me lembro do nosso último encontro e vou agora identificando, nos retalhos que me chegam sobre o que você pretende fazer, os pedaços de alguma carta rasgada e atirada ao vento, suja de lodo e de sangue, molhada do suor agoniado de você entre dois pesadelos, no meio de baleados e afogados, perdido nos meus braços feito um menino, os olhos embaciados dos mortos olhando você feito olhos de peixe do fundo do açude, espreitando você, só uma vez, uma noite, porque quando o dia foi saindo, e quando cada manga, perdurada do galho em seu cordão, levou na cara rosada um raio de sol, você tamb'em recobrou as cores, o riso, e começou a falar que se trata de mulher muito traída, muito maltratada, mas empedernidamente honesta, e que você, cansado de arrastar aqueles que ao teu lado morreram de amor por ela, ia dar um porre nela, conquista-la na raça, 'quando ela estiver bem tonta entro no quarto dela fingindo de marido', imagem que achei pouco lisonjeira, em relação a mim, mas que passo a louvar, disposta a abrir para você a porta, embora lamente não estar eu mesma no quarto, deitada na cama, pronta para ser lavrada, semeada, comida." (p.p 39 a 40)

Juliana abre as portas para o sucesso do sequestro do embaixador Clay, porém Beto não chaga a adentra-las, pois morre antes mesmo de concretizar seu plano, que acaba sendo finalizado pelos companheiros Vitor, Dirceu, Mejia, Amália, Válter, Valdelise e Bernardo.

A jovem, que não conseguira integrar-se nem à realidade brasileira, nem aos conspiradores e tambpouco a sua família, vê o único e frágil sentido da 
sua vida desmanchando-se nas águas barrentas que deveriam invadir, antes sim, a casa de seu pai. Tendo rompido com as suas origens a fim de ligar-se visceralmente ao universo do namorado, ela não assimila a sua morte, pois não consegue compreender como e por que Beto tivera que abandoná-la em um mundo no qual não conseguira identificar-se com quaisquer dos papéis que desempenhara.

A utopia matriarcal - presente em Quarup e em Bar Don Juan - é abortada em Reflexos do Baile. Apesar da firmeza e disciplina com que desenvolve suas ações, Juliana não consegue libertar-se dos terrores da repressão, tornando-se vulnerável às suas garras e pondo fim à possibilidade de, como Laurinha, reconquistar a esperança de construir uma sociedade justa e igualitária e gestar os caminhos para a consolidação de uma nova utopia.

Rufino, ao tomar conhecimento da opção da filha, exila-se em algum canto da sua subjetividade como ela mesma o faz, passando a falar e agir como estrangeiro e marginalizando-se de todos os acontecimentos. É o que se lê na carta que o embaixador britânico envia a Clay, na qual desabafa o tormento em que sua vida se transformara desde o momento em que Rufino decidira assumir sua personalidade, seu cargo, até seu robe:

“ Meu caro Clay: (...) E, com mil raios, Clay, Rufino começou de pronto a me tratar como se eu fosse o adido de imprensa ou algum dos novatos da Embaixada. Não me apraz arriscar avaliação ou opinião médica do caso, mas Rufino transformou-se em mim, isto é, Embaixador Britânico. Já me ditou uma carta de cortesia e agradecimentos ao Governador-geral da Ilha Maurício ( esteve lá recentemente ganhou de presente um doudo empalhado ) e diz que esboça uma outra à Rainha, denunciando o Governo brasileiro por quebra dos direitos extraterritoriais dele, Rufino (...) 
Em tempo algum me ocorreu que me visse um dia forçado a distrair e a mimar meu próprio doppelganger. No momento, Rufino não se cinge a ler diante de mim o Observer e a manter cativo no colo o T.L.S, que ain- da nem abri, como - é melhor confessar de uma vez a verdade pura e sim- ples - o robe que veste é o meu próprio, de Jaeger’se, Clay. (p.p 112, 113)

Pai e filha encontram-se, ironicamente, aos olhos do grupo revolucionário e do corpo diplomático, na loucura, pois ambos rompem com o mundo. $\mathrm{O}$ primeiro, porque desliga-se do passado e da sua história de vida, assumindo uma outra identidade, e a segunda, porque fica presa à morte de Beto, sem nem conformar-se e nem rebelar-se contra o fato. Nenhum dos dois encontra um centro que lhes restabeleça o sentido da vida e, se não conseguem encontra-lo, é porque o almejado centro perdeu-se por entre os cacos da realidade. Tampouco conseguem um ponto de equilíbrio como os demais personagens - policiais, revolucionários, e diplomatas - porque pai e filha perdem-se por entre as imagens distorcidas que a realidade projeta.

O percurso traçado por Rufino e por Juliana traduz a incompatibilidade entre as figuras e as máscaras ${ }^{1}$ que os personagens vestem. Rufino, diplomata aposentado que acredita ter a obrigação de representar com altivez a nobre linhagem a que acredita pertencer, esmera-se em escrever um diário - que se torna, ao longo da narrativa, o principal fio condutor para a construção desse personagem - no qual desabafa todas as suas dúvidas e paixões. Beirando o pedantismo, Rufino peca pelo quase excesso de ingenuidade com que vê o mundo e pela cegueira que mantém com relação a

\footnotetext{
${ }^{1}$ Ligia Chiappini, no seu ensaio "Sempreviva: ‘ainda um grito de vida e voltar'., utiliza a oposição 'máscara' e 'figura' para discutir a questão da representação social versus a identidade pessoal: “... até que ponto os papéis que representamos podem convencer aos outros e a nós mesmos, deixando marcas definitivas?”. (p.207) (Op.Cit)
} 
si mesmo e a sua filha Juliana. As páginas do seu diário, repletas de referências a escritores, nobres e objetos de luxo, traçam o perfil desse homem que imagina ser um pensador e compreender o mundo, mas que não consegue ver além da aparência das coisas e dos seres e que vive obcecado pelas imagens de um passado paradisíaco al qual gostaria de voltar.

Quando percebe que fora traído e manipulado pela filha, reconhece em seu mundo as imagens falsas que ele mesmo criara, de si e dos outros. Com o desvendar abrupto das verdadeiras identidades daqueles que o rodeavam até mesmo o jardineiro Válter não passava de um disfarce incorporado por um dos revolucionários - Rufino apropria-se da identidade do Embaixador Britânico e faz dela a sua máscara, acabando por aderir completamente à ficção que inventara para defender-se do seu mundo estilhaçado.

A convivência desarmoniosa entre figura e máscara apresenta-se na construção do corpo diplomático como um todo, uma vez que os embaixadores, longe dos países de origem, não se identificam com o Brasil e tampouco com seus problemas e sua gente, o que lhes rende uma adaptação problemática ao espaço em que vivem e, consequentemente, uma profunda crise de identidade.

Carvalhaes, o embaixador de Portugal, encarregado de trazer os ossos de Dom Pedro I para o Brasil, alterna entre a imagem idealizada de um Portugal poderoso e rico e a constatação da deselegância dos brasileiros, que permaneciam imersos numa comunidade primitiva e degradada. Ao conhecer Juliana, porém, apaixona-se por ela e deixa-se seduzir por costumes que outrora cria serem de péssimo gosto. O embaixador português desmancha-se por entre gestos e discursos frívolos para convencer Juliana de suas 
qualidades, porém, aos olhos argutos dela, Carvalhaes representa uma ridícula peça cômica.

As cartas dos demais embaixadores e de suas mulheres reforçam o deslocamento dessas pessoas que se sentem aristocratas em um país que nada mais possui além de uma exuberante natureza. É o que se lê, por exemplo, em uma carta do embaixador americano, Clay:

“Querida Melaine: acho que pelo menos de uma forma literal, não-metafórica, vou ter meu caminho atravessado por aquele tigre. Será uma onça, que certamente não é o maior dos felinos, mas que atinge de qualquer maneira a um porte aceitável(...) Que mais vou te contar? Eu me sinto como antigo romano em algum posto avançado da África ou do Danúbio (...) Ah, em tempo, tive ontem à noite um sonho esplêndido, vivido a mais não poder. Esvaziei inteiramente o Brasil de gente e enchi-o de beija-flores." (p.41)

Os revolucionários e os policiais enriquecem a vasta galeria de máscaras que Reflexos do Baile apresenta: os primeiros, porque não podem assumir suas verdadeiras identidades, e os segundos, porque, além de terem que se infiltrar entre os revolucionários, estão submetidos a uma estrutura de poder atroz, o que os condiciona a buscar máscaras igualmente atrozes ${ }^{1}$. Descobrir a identidade de cada personagem torna-se, por isso, tão difícil quanto decifrar os acontecimentos que se sucedem no Brasil, sempre encobertos com subterfúgios.

Não é possível afirmar se os sentimentos e os gestos denunciados nos papéis expressam a verdade ou mascaram temores e culpas. Os limites da verdade e da mentira diluem-se em meio a um perigoso jogo, escorregadio

\footnotetext{
${ }^{1}$ É em Sempreviva que Antônio Callado explora e aprofunda o jogo que os policiais fazem entre máscaras e figura, conforme teremos a oportunidade de ver.
} 
demais para que a narrativa se valha, como nos dois romances anteriores, de um narrador que denuncie a hipocrisia inerente às relações sociais.

O leitor é obrigado a aderir ao baile das máscaras e a buscar nos silêncios os principais caminhos interpretativos desse texto literário: calados em seus temores, os revolucionários sofrem as duras consequências da luta desiqual contra o regime autoritário, enquanto a população, assustada com a capacidade do governo em violentar física e moralmente os seus opositores, mergulha no mais profundo silencio ${ }^{1}$.

À legitimização da mentira como meio de sobrevivência, cada bilhete da narrativa ganha autonomia por aquilo que procura ocultar e cada ocultamento é a revelação das histórias que deslizam por entre os porões da ditadura. Para decifrar os silêncios, cabe ao leitor entender os estreitos diálogos que o livro mantém com o meio jornalístico, com a história e com a própria literatura. São fartas as referências que a narrativa faz a essas três áreas da atividade humana e são exatamente essas referências que irão possibilitar a compreensão de todas as mensagens cifradas presentes em Reflexos do Baile.

A imparcialidade e a objetividade, costumeiramente atribuídas ao discurso jornalístico, é o ponto de partida deste romance, uma vez que a narrativa adere a um suposto olhar neutro, o que daria voz a todas as partes envolvidas

\footnotetext{
${ }^{1}$ Importante faz-se lembrar que parte significativa da população não se envolveu com as reivindicações das esquerdas, ou porque as classes mais oprimidas não se sentiam verdadeiramente representadas por elas, ou porque as classes sociais mais favorecidas mostravam-se satisfeitas com algumas das 'concretizações' dos governos militares (Ver: Mendonça, Sônia e Fontes, Virgínia. História do Brasil recente (1964-1992). A própria censura dos meios de comunicação - proibidos de divulgar e de explorar os casos de torturas e das cassações políticas - e a intensa propaganda que o governo promovia sobre a sua administração foram fatores determinantes para impedir a formação de uma consciência crítica por parte da população. Se por um lado este fato desmente o temor das pessoas com relação à força do poder militarizado, por outro lado corrobora a tese de que as décadas de 60 e 70 debateramse por entre as mais astuciosas mentiras, seja porque não fosse possível divulgar a verdade, seja porque a população ao não se identificar com as propostas das esquerdas, praticamente ignorasse as meias verdades que a ela era dado conhecer, seja porque os representantes mais imediatos da população, como os sindicatos, estavam sob a intervenção do governo militar.
} 
como, teoricamente, pretende a grande imprensa. Esse diálogo entre a narrativa e o jornal estende-se à estrutura do livro - uma montagem de textos que remete ao trabalho de edição de jornal - e à seleção de informações que se tornam material de ficção: as enchentes no Rio de Janeiro, a visita da rainha da Inglaterra ao Brasil, o sesquicentenário da Independência, comemorado com a chegada dos restos mortais de Dom Pedro I.

Reflexos do Baile, trabalha com tais pressupostos jornalísticos, mas não para na simples elaboração desses. A partir da reconstrução do discurso dos jornais, Callado ironiza-o, já que a narrativa acaba por denunciar a impossibilidade da elaboração objetiva e imparcial de um texto.

A disposição e a seleção dos bilhetes, bem como o confronto entre os diversos enunciados que eles apresentam, impedem que a narrativa desempenhe o papel de acompanhar com lisura e verdade os fatos: a obscura armação do texto ficcional, mas, fundamentalmente, dos próprios acontecimentos históricos veiculados pela imprensa que serviram de matériaprima para a composição da trama que compõe Reflexos do Baile.

Antônio Callado, portanto, ao procurar plasmar a linguagem jornalística, coloca em xeque a imagem que a imprensa escrita tanto se esmerava em divulgar, propondo ao leitor o desafio de compreender que o conteúdo, a construção e a própria seleção dos dados dos discursos jornalísticos estão subordinados a uma determinada ideologia, a qual, nas décadas do terror, não poderia ser outra senão a das elites governistas.

O caráter dialógico do livro, imediatamente identificado na sua composição por mensagens cruzadas, torna-se mais complexo à medida que 
a ironia dos referenciais externos ( os discursos jornalísticos ) contamina os referenciais internos ( a revolução militar, as movimentações da esquerda e o imaginário utópico elaborado em Quarup e em Bar Don Juan ). Tal ironização acaba corroendo, em última instância, a própria narrativa, que não possui outra base de sustentação para a sua existência a não ser o diálogo que mantém com o período histórico e com os discursos, jornalísticos e ficcional.

Nesse contexto, verifica-se a fragilidade dos personagens e a ausência de uma coerência que permeie suas ações e reações. Beto, ou capitão Roberto, planeja cuidadosamente os passos do sequestro, enquanto os policiais, já em seu encalço, cuidam para evitar aquilo que garantiria o tom épico da ação revolucionária, o alagamento da região e o corte da luz elétrica:

"Senhor Chefe do Serviço de Segurança: é claro que esse indivíduo, quando afinal o Serviço conseguir identifica-lo e prendê-lo, deve ser julgado e punido, por sedição, por sabotagem, pelo diabo que o carregue: porém, como um pobre coitado, e nada mais. Poderemos, para compensar o trabalho que nos deu que está nos dando ainda, Deus sabe - cair na tentação de lhe exagerar as proporções. Mais importante do que castigá-lo, ouvi-lo em confissão, ou exterminalo é caracterizar seu pobre-coitadismo. Estamos no encalço dum cabra esperto, inteligente mesmo, duma inteligência instintiva, voltado para a faina de nos desmoralizar, pois tudo indica que veio, passo a passo, atrás de nós, da zona adusta para o vale do Paraíba e a cidade do Rio. Terá lá seus encantos pelos jagunços e fanáticos e seguramente fomentou ele esse retrato psicológico de quem não conhecemos a cara, o que nos cabe fazer, sobretudo é não fazer-lhe o gosto, e não deixar que chegue seu nome ou apelido àqueles folhetinhos que se penduram pelo cordel na cadeira dos engraxates ou à choradeira desdentada dos cegos de feira de Trogloditia (...)" (p. 60) 
Os policiais, embora tivessem ficado desconfiados da conspiração que se tramava no Rio de Janeiro, se não conseguiram evitar o sequestro do embaixador, mataram ou torturaram outros tantos revolucionários, descompensando ainda mais o quase nada que restava das minguadas organizações de esquerda.

Desvendada pelos policiais toda a trama que se armava cuidadosamente, os acontecimentos revelam as artimanhas do poder repressor. Os revolucionários são chamados a trocar a máscara, mas também os policiais, ao final da narrativa, quando as denúncias contra os torturadores começam a incomodar as autoridades e a realidade parece querer despontar por entre os montes de calúnias.

Escamoteados pelo discurso oficial, os fatos pulsam a cada bilhete trocado entre os revolucionários, questionando, numa linguagem crifada, quase incompreensível, a versão oficial:

"Dirceu: à companheira Juliana declarei: a malandragem quando se sai do inferno é não olhar para trás: lembrai-nos do camarada Orfeu. Conclusão: nem me ouviu, pensando do camarada Beto que, crucificado como um sino em seu campanário, continuará com voz de bronze a chamar Juliana ao amor e os paralíticos ao baile. Argumento: acho que não há inconveniente em fazer a vontade à nossa Orféia, que tem documentos para sair sem qualquer problema do Reino dos Mortos e chegar a Montevidéu e que só me impõe a mim, seu Chevalier servant, para que lhe salve a vida, um condição: parar o carro um instante em Padre Miguel onde quer aspirar a terebintina do quintal preto de mangueiras de uma casinhola onde ela se encontrava - um doce se você adivinhar com quem.” 
Os sonhos, os desejos, as lembranças, as profundas mágoas e os temores desses jovens chegam-nos misturados com os discursos da repressão que os transformam em assassinos e terroristas. A grandeza das ações revolucionárias reduzem-se a movimentos subversivos e a história oficial encobre a realidade.

Os conflitos vividos pelos revolucionários não se limitam ao desejo de transformar a sociedade e extinguir o autoritarismo no Brasil, estendem-se à insatisfação com relação à vida a que eram obrigaos a levar e à impossibilidade de construírem algo que lhes proporcionasse satisfação pessoal, sexual, amorosa, como torna-se evidente nas palavras de Juliana:

"Beto: (...) você sorriu, divertido com o medo que eu sentia e falou numa voz cavernosa: 'O amor desembainha a gente, feito uma espada', e aos poucos, sorrindo, você entrou em mim de novo, até os copos. Naquele dia você me forjou, fez uma espada. Quando eu sai do fundo da cisterna fiquei tão acordada no escuro que enxergava tudo, feito uma coruja, chorei de raiva por não ter perguntado mais a você. Não se chega nunca? Não se para em algum lugar, para fazer casa e filho? Mas vi logo que minha raiva era ver você de novo, ter você na cama comigo. Aço teu, bainha eu." (p. 36)

A relação entre Amor e Revolução tão presente em Quarup e em Bar Don Juan mais uma vez é construída nesta narrativa, assim como o será em Sempreviva. Esse tema, assim como o do conflito entre subjetividade e realidade, o da idealização da figura feminina e o da busca da identidade nacional, são indispensáveis para esses romances de Antônio Callado, que 
buscam propor uma reflexão crítica sobre o movimento revolucionário. Esses temas, tratados de maneira diferente em cada romance, aprofundam, universalizam e problematizam o projeto nacional e popular proposto pela esquerda, que se apresenta como restritivo, uma vez que não contempla os vários brasis e despreza as reais necessidades e desejos da população.

As diferentes visões que os romances constroem sobre o período ditatorial impulsionam o leitor a compreender que as narrativas transcendem a problemática primeira a que se propuseram tratar, a derrocada das esquerdas, e sugerem que se inicie, urgentemente, a reconstrução da perspectiva utópica, pautada em uma discussão franca sobre os limites do engajamento do homem moderno na luta pela construção de uma sociedade justa e igualitária.

Sem dúvida, a relação entre Amor e Revolução humaniza o movimento revolucionário, visto pela sociedade daquele período como algo abstrato, genérico, um movimento composto, basicamente, por jovens da classe média que não possuíam rostos, identidade, vida privada. Reflexos do Baile, Bar Don Juan e Quarup chamam a atenção do leitor não apenas para as histórias terríveis que corriam pelos cantos escurecidos do país, mas para os lastros que elas consolidavam ao provocarem a absurda desumanização dos oprimidos.

Seduzida pelo 'milagre econômico', a classe média dividia-se entre o conforto que a economia proporcionava nas grandes cidades e a indignação revolucionária dos seus filhos - guerrilheiros que queriam fazer a revolução popular, mas que, a cada dia, viam-se mais longe do seu povo. Pelo desejo de manter privilégios ou pelo temor do destino dos filhos, a população

\footnotetext{
${ }^{1}$ Mendonça, Sônia Regina de e Fontes, Virginia Maria. História do Brasil Recente (1964 - 1992). (p.p. 7 a 51 ) (Op. Cit.)
} 
tornara-se tanto mais conservadora com relação a uma pretensa transformação social, quanto cega para os crimes que o governo cometia contra a sociedade brasileira:

"Por volta de 1973, tanto o Estado quanto as oposições cuidavam de rever estratégias e rumos. As tentativas de definir novos instrumentos de legitimação do regime multiplicaram-se durante o período Médici, apoiando-se no binômio segurança nacional / desenvolvimento. A tendência era condicionar, cada vez mais, a legitimidade do governo ao seu grau de eficiência na esfera econômica e financeira. A vigência do 'milagre' entre 1968 e 1974 forneceu o suporte a este processo. A própria forma com que eram produzidas as comunicações oficiais denota essa estratégia - enfatizando dados essencialmente técnicos - que buscava a criação de uma nova linguagem despolitizadora das informações governanmentais."

Frente à condução política e econômica do país e a intensa propaganda governamental, a população resiste em acreditar nas versões não oficiais disseminadas pelas vozes frágeis das esquerdas e os revolucionários tornamse tristes e asgustiadas figuras reduzidas à imagem de jovens agitadores e irresponsáveis.

Quando se é possível distinguir na orquestração de vozes que Reflexos do Baile compõe a fina relação entre o amor de Juliana por Beto e o seu engajamento na ação revolucionária, vê-se que está fora de cogitação a unidade possível - buscada por Nando e por Laurinha - entre Amor e Revolução. Se nos romances anteriores há a fugaz, porém verdadeira, integração entre subjetividade e ação política ( por exemplo, a cena em que Francisca e Nando separam-se da expedição ao Centro do Brasil, para

\footnotetext{
${ }^{1}$ Idem, ibidem (p. 49)
} 
concretizarem a relação sexual há tanto esperada em meio a uma paisagem absolutamente romantizada; ou mesmo as cenas de Bar Don Juan que descrevem os amores de Gil e Mariana, acontecendo também numa espécie de paraíso tropical , ) em Reflexos do Baile, embora ela desponte, não se efetiva, pois que se rompe antes mesmo de ser totalmente vislumbrada no horizonte repleto de mortes e de dores:

"Dirceu:(...) Juliana estava como tinha falado a empregada, cabeça baixa, revista no colo. Ainda bem ela levantou os olhos, fazendo força como se tivesse pálpebra de chumbo mas levantou, e aí sorriu, chamou a gente com a mão e a Joselina (empregada) se mandou. Só de abaixar os olhos de novo ela mostrou à gente a foto que saiu no exterior do Beto dentro dágua até o cinto queixo enfiado no peito cortado de cordas no meio daquele porção de canoas cheias de gente flutuando em volta duns telhados e do toco da torre." (p.89)

Vitor, outro dos muitos admiradores de Juliana, e outros companheiros querem que Juliana viaje por algum tempo, mas ela, mesmo com o assassinato de Beto, faz questão de concluir o plano para o sequestro do embaixador:

“'Vou sim. Viajo para onde vocês quiserem. No dia seguinte.' 'Seguinte? A que?' 'Ao baile que o beto marcou.' Aí, Dirceu, a companheira fez uma doce tentativa mal sucedida de sorrir. 'Com o noivo acontece, mas a noiva nunca deixa de aparecer para as bodas'." (p. 89)

Juliana conclui a ação armada e põe em prática a síntese entre a relação amorosa e o ato revolucionário. Porém, essa síntese é a expressão do 
estilhaçamento que as certezas revolucionárias e a intimidade dos personagens sofreram sob a violência do estado e não a expressão da satisfação dos homens para com suas vidas pública e privada.

Reflexos do Baile questiona a unidade possível entre amor-revolução e subjetividade-coletividade que Quarup e Bar Don Juan deixam vislumbrar enquanto proposta para que se realize a efetiva transformação da sociedade a revolução interior do homem promoveria a revolução social e esta, aquela - e anuncia a necessidade de, diante do esgarçamento do tecido social e da intimidade dos homens pela ditadura militar, reformular os parâmetros para a construção de uma nova utopia.

Nessa medida, Reflexos do Baile reverte o imaginário dos romances anteriores e compõe a história de uma derrota. Porém, esta narrativa representa, sem dúvida, uma conquista dos que sofreram a violência do estado repressor por terem a sua história resgatada, ainda que fosse para lamentarem-se dela:

“O problema dos escritores da década de 70 e, embora com algumas diferenças, desta década de 80 que se inicia, parece ser o problema de Gil, do Bar Don Juan. Escrever é resistir à fragmentação que ameaça destruir o romance, resistindo também à hibernação da pátria, dentro do exílio de cada um."

É assim que Vítor, aquele que, num primeiro momento, poderia ser entendido como o 'herói' de Reflexos do Baile, resiste, sonhando com que

\footnotetext{
${ }^{1}$ Lígia Chiappini. "Quando a patria viaja: Uma leitura dos romances de Antônio Callado”. (Op. Cit. - p. 170)
} 
os Betos, as Julianas, as Amálias sejam, um dia, parte da memória dos brasileiros.

Vítor, o basco, é quem assume o primeiro plano da narrativa e é ele quem, acalentando uma paixão platônica por Juliana, acompanha-a até o dia da sua prisão e morte. Preso pela repressão, o basco resiste às torturas e, ao tomar conhecimento do assassinato de Juliana e de Amália, essa, sim, mulher com a qual manteve uma relação amorosa, desafia a polícia dentro do seu idioma materno - língua que curiosamente não tem diálogo com nenhuma outra:

"Senhor Secretário de Segurança: (...) O senhor pode ouvir as duas fitas no gravador. Compare e veja. O cara (Vitor) ficou assim feito quem quer morrer de propósito, entrando nele mesmo e falando tão enrustido que nem se escuta na gravação, é só aquele sopro. Mas num jeito de zombaria, quer dizer sem ligar para a gente de olho no teto e falando todo tranquilão(...) eu de princípio falei sério com ele, Moço você me respeite, e ele nada, na mesma sacanagem, Moço eu não sou moleque e ele ai como o senhor pode ouvir na fita partiu para a chacoalhação braba com o tal de só dizer araman ziñuben su, araman ziñuben zu, araman, ziñuben zu.”(p.123)

Com a fragmentação de todas as categorias narrativas em Reflexos do Baile, também este 'herói' passa a existir apenas enquanto um possível esboço, inacabado e brumoso aos olhos do leitor que anseia por encontrar algum traço bem definido nesse caos literário. Vitor não chega, sequer, a constituir-se enquanto o 'anti-herói' ( conforme veremos ocorrer com Quinho, em Sempreviva ), já que não desfruta do privilégio de ter um perfil de contornos claros ou mesmo uma sequência de ações concluída. Entrevêse, apenas, a coragem e o medo que povoam os bilhetes enviados, além do 
profundo sentimento amoroso por Juliana, que não chega, porém, a concretizar-se.

A identificação dos personagens Vitor e Beto com Nando e Levindo é imediata. $\mathrm{O}$ basco passa a assediar Juliana - que também se identifica com Francisca - após a morte de Beto, assim como Nando o faz com relação à Francisca quando morre Levindo. Ambos, Vitor e Nando, frustram-se diante da negativa das mulheres amadas, fiéis que são aos antigos companheiros mortos.

O destino do basco, porém, é ainda mais trágico, pois, além de não ter podido experimentar nenhum momento, ainda que fugaz, de plena satisfação amorosa, não teve tempo sequer de dar vazão a sua intimidade, ao seu amor. Não teve, aliás, tempo de decidir sobre o seu futuro, como, de alguma forma, Nando o faz.

A admiração que o padre tem por Levindo repete-se no sentido que Vitor nutre por Beto. Todavia, o basco não pode adentrar o universo prosaico de Nando, pois tem que se concentrar em driblar a repressão ao invés de resolver seus conflitos pessoais. Por isso, ao contrário do protagonista de Quarup, Vitor não digere por meses a morte de Levindo, que passeia na alma do ex-padre sempre a provoca-lo para longas reflexões e profundos mergulhos em si e no Brasil. O revolucionário de Reflexos do Baile não pode ceder às emoções provocadas pela morte de Beto e só pode traduzi-las na linguagem cifrada a que se submeteram os conspiradores. Devendo soterrar suas dores e seus desejos, Vítor faz da imperiosa necessidade de estilizar o discurso para burlar a repressão um constante, e surpreender, fazer poético, como o que se lê quando, escrevendo a Mejías 
( o 'possível sobrinho' do toureiro Ignácio Sánchez Mejías, PRANTEADO POR Garcia Lorca ${ }^{1}$ ), ele fala da morte de Beto e, sem o saber da sua também:

\begin{abstract}
"Por haver uma cornada mortal em 1935 um possível tio teu inspirou versos de sangue, de areia e de iodo enquanto nós não asbemos sequer a que horas morreu Beto, em ponto. O outro, teu tio, espada em punho, no dia raro em que a rês foi mais ladina que o sacerdote assassino, presidia a um antigo rito de sangue. Beto foi o touro, o cordeiro imolado, Issac num desses momentos nada raros em que o Senhor se atrasa em sua nuvem. E não tenho versos para ele, só tenho esta raiva, este gosto de sal na boca, e a certeza de que levará muito tempo a nascer entre nós, se é que nasce, outro touro tão denso de amor e de vida mas, embora não saibamos a hora, morto, muerto para siempre como todos los muertos de la Tierra." (p.p. 90 e 91)
\end{abstract}

Se Vitor não chega a se constituir enquanto 'herói', tampouco Beto conquista uma identidade ao longo do livro. Ocorre que a meneira como se dá a sua morte acaba por promover a mistificação da sua figura: na região toda inundada pelas águas da represa, a qual o ex-capitão esperava usar para inundar a embaixada no dia do baile, o revolucionário é assassinado pela repressão e o seu cadáver pendurado pelo peito na única parte seca, a torre da igreja, "para todo o mundo ver os cornos da apóstata e renegado" (p. 87)

\footnotetext{
${ }^{1}$ Lorca, García. "Pranto por Ignácio Sánchez Mejias” ( 1935 ), p.p. 510-521. ( Esta informação bibliográfica foi retirada do belo livro de Regina Dalcastagné. O espaço da dor. O regime de 64 no romance brasileiro. p.60, Brasília, Editora Universidade de Brasília, 1996 - no qual são analisados nove romances que, segundo a autora, se 'propõem esmiuçar a vida sob a opressão, seus caminhos possíveis, seus desvios'.
} 
Contudo, as pessoas não temeram o destino daquele que traiu a sua corporação e a sua pátria - como desejavam os policiais- , mas manifestaram a mais intensa admiração pela vida do homem que teria morrido em favor das causas populares. A história de Beto alude mais uma vez à história de Levindo, que foi celebrado em um jantar, promovido por Nando, devido à luta que travara contra os latifundiários e a favor dos camponeses.

A repressão responde às manifestações populares que se dão em torno do assassinato de Levindo, em Quarup, e de Beto, em Reflexos do Baile, com ferocidade e transforma, mais uma vez, as vozes do povo em lamentos a serem ruminados nas mentes ruidosas e nas ruas silenciosas:

“Capitão: Ordens são dadas para ser cumpridas. À risca. Tire imediatamente o corpo desse Beto ou como se chame de onde se encontra. O cadáver deve ser levado para o Cemitério da Capital, enterrado sem acompanhamento num canto de indigente, sem cruz em cima, sem choro, sem vela, sem nada. Que tirem daí o bandido hoje, já, que o transportem e enterrem. Tivemos faz pouco o trabalho e a despesa de afogar Canudos em baixo do Cocorobó. Que idéia da roça é esta agora de improvisar um monumento com um desertor e uma torre e inventar alguma romaria de basbaques e subversivos nesse Canudinho de merda? Cumpra as ordens. Enterre o traidor.” (p.88)

O chefe de polícia chama a atenção do seu subordinado, pois teme que a mistificação do morto fomente a reconstrução das histórias das quais ele teria sido o mártir, o que, fatalmente, se não chegaria a alterar a memória social, ao menos arranharia o discurso monocórdico, revelando alguns dos graves ferimentos da História recentíssima do Brasil, que tanto deram trabalho para serem atados e cobertos antes mesmo de cicatrizarem-se. 
Há, nos três romances já estudados neste trabalho, a construção de personagens que, aos olhos dos companheiros, por terem sacrificado uma possível felicidade pessoal em favor de uma utopia social, seriam os mártires da Revolução ${ }^{1}$ : Levindo descarta a possibilidade de construir uma vida tranquila com Francisca e morre lutando pelos camponeses; João desprendese da vida confortável de um intelectual de classe média para pôr em prática as ações revolucionárias por tanto tempo idealizadas; Beto troca sua vida pela esperança de soltar alguns companheiros e pela fé inabalável de que a revolução ocorrerá.

A maneira como morreram Levindo, João e Beto e a fé cega que eles tinham na luta revolucionária levam os companheiros a idealizá-los transformando-os em símbolo do amor, livre e incondicional, ao povo.

A construção desses símbolos, exemplos de generosidade e fraternidade, revela aquilo que o processo revolucionário das esquerdas deveria possuir para alcançar o sucesso: homens que conseguiram fundir o universo íntimo à realidade nacional, a experiência privada à experiência social, e reinventar os princípios da felicidade, não mais subordinados apenas às realizações pessoais, mas também às coletivas, já que uma dependeria da outra.

Porém, esses homens, com suas histórias de vida idealizadas e romantizadas, não correspondem aos personagens mesmos dos romances. A imagem construída deles encontra o seu correspondente, isto sim, nas figuras femininas, em Francisca e em Laurinha ( Juliana, como vimos, tem uma morte prematura ), uma vez que são as únicas a conseguirem unir as duas pontas da vida, a subjetividade à realidade.

\footnotetext{
${ }^{1}$ A relação entre História e Misticismo também está presente em Sempreviva, porém apresenta-se de maneira bastante especial, conforme se verá no próximo capítulo.
} 
A mistificação de eventos e de personalidades torna-se fundamental na condução dos enredos, pois possibilitam a construção, silenciosa, da memória histórica das esquerdas. A narrativa ficcional torna-se um interlocutor para os revolucionários refletirem sobre o movimento e sobre a sua própria condução política.

Antônio Callado chama a atenção para o quanto as imagens idealizadas dos revolucionários são necessárias para que os homens resistam à violência ditatorial. A mistificação das personalidades seduz a população e cria heróis que passam a povoar o imaginário de uma humanidade tão carente de pessoas autênticas e de ações nobres, as quais, pessoas e ações, invadem a memória histórica de uma nação, podendo mesmo vir a romper com a letargia a que a pátria é submetida quando se encontra sob o jugo do poder opressor.

Além de Callado apontar para o fato de eu o período ditatorial retardou a evolução da história da humanidade para a almejada sociedade igualitária, reforça a ideia da mercantilização que as relações humanas sofreram neste século $^{1}$. Estilhaçado o universo interior pelo valor econômico que os homens atribuíram a suas vidas, a realidade, reflexo da ação conjunta que as pessoas exercem sobre o mundo, fragmenta-se e torna-se inapreensível e incompreensível ${ }^{2}$.

\footnotetext{
1 “A individualidade agoniza nas sociedades burocráticas e aburguesadas, nas quais nada escapa às leis do mercado, nas quais o homem só existe como sujeito e objeto econômico. Nelas se verifica um processo de fragmentação da identidade e de 'multilação do ego', não há mais espaço para o prazer, para o amor desinteressado e gratuito: o indivíduo sucumbe à produtividade que impõe suas regras contra tudo que se lhe apresente como produtividade." (In: Matos, Olgária. "Reflexões sobre o amor e a mercadoria" (1978) História Viajante: notações filosóficas. São Paulo, Studio Nobel, 1997, p. 109)

${ }^{2}$ Lukács explora com muita propriedade a fragmentação do homem e da realidade como vimos nos capítulos anteriores, porém, pretende-se acrescentar à sua abordagem a mercantilização das relações humanas promovida nas sociedades modernas. ( Ver matos, Olgária. Idem, Ibidem. p.p. 109-117 )
} 
Dessa maneira, o autor elabora a ideia de eu o desafio eu se coloca aos revolucionários está por demais acima das possibilidades humanas de superá-lo: além de o homem ter sucumbido às leis do mercado, de não conseguir manter sua individualidade e identidade pessoal, de desesperar-se com a ausência de um sentido para a vida, encontrar-se, mesmo, impedido de conseguir resolver tais conflitos e de projetar o devir, pessoal e coletivo, pelas terríveis estratégias eu o estado ditatorial adotou para exterminar os questionamentos relacionados à arbitrariedade com que as elites conduziam os rumos do Brasil.

É esta violência, poderosa e anônima, que a mulher do embaixador inglês entrevê e expressa, num rasgo de lucidez, em uma carta enviada à amiga Penélope:

"Estou na maior fossa. Acho que é melhor você rasgar minhas cartas. Henry vive apavorado com a ideia de que tudo que a gente diz hoje em dia de um jeito ou de outro acaba irradiado pela BBC e de que tudo o que se escreve vai parar no Observer ou Deus nos livre New of the World. Acha que já enviou um número suficiente de relatórios ao Foreign Office a respeito da Festa, todos dizendo, ou dando a entender, que se não se levar em conta o que foi engendrado depois na porcaria dos jornais locais ou nos despachos de jornalistas americanos, tudo convergiu para o evento de um Baile perfeito. Bom, a novidade é que a moça Juliana morreu, brutalmente assassinada pela Polícia, ou pelo Governo, nunca se consegue apurar nada neste país. Ah, Penny, tenho a sensação esquisita de que estamos triturando alguma coisa frágil que tenta nascer aqui, esmigalhando, aleijando para sempre não sei o que. Há este chão escuro e trêmulo eu mal olhamos e no qual pisamos com sólidos sapatos." (p. 101) 
É como se a igualdade e a justiça social proclamadas por Marx e Engels no Manifesto Comunista ${ }^{1}$, eu deveriam ser conquistas, segundo os autores, através de uma intensa luta do povo contra as elites - a qual só se daria depois de um longo processo de amadurecimento e politização das classes oprimidas - tivessem sido condenadas ao fracasso no Brasil pelo incrível poder do estado de conduzir a vida nacional.

Esse poder revela-se em Quarup, Bar Don Juan, Reflexos do Baile e em Sempreviva na capacidade de as elites brasileira utilizarem-se dos meios mais abjetos para manterem-se no poder: o extermínio dos povos indígenas, o analfabetismo crescente, a manutenção do estado de miséria da população, a corrupção livre e irrestrita, até a violência moral e física contra todos os cidadãos. Tamanha opressão impossibilita aos homens de reconstruírem, primeiro, suas individualidades e, consequentemente, o próprio tecido social, para, então, poderem lutar por uma condição histórica mais fraterna e igualitária.

Callado percebe o abismo existente entre o desejo de transformação de alguns jovens e a situação nacional e entende eu a politização das classes oprimidas e a luta revolucionária só será possível quando não mais exigirem dos brasileiros o sacrifício absoluto de suas vidas já tão esgarçadas pela realidade brasileira.

Os romances de Callado propõem, portanto, um "adendo" ao Manifesto Comunista, antes da ação revolucionária faz-se necessária a revolução do próprio homem. Para tal aprendizagem é preciso, porém, tempo e espaço, e é com a manipulação destes eu a repressão contou para vencer a guerra contra os revolucionários.

\footnotetext{
${ }^{1}$ Marx, Karl e Engels, Friedrich. Manifesto Comunista. Org. Osvaldo Coggiola. São Paulo, Boitempo, 1998 (p.p. $37-69)$
} 
Esta é a diferença fundamental entre Quarup e Reflexos do Baile, não apenas no que se refere ao tempo de eu os personagens desfrutam e ás distâncias que percorrem do país, mas ao tempo do próprio romance: no primeiro, a linguagem é caudalosa, os monólogos interiores e as ações multiplicam-se, o enredo explora a floresta, o campo, a cidade, e o livro é longo ${ }^{1}$; no segundo, a linguagem é cifrada, não há monólogos interiores, o enredo concentra-se na cidade e em um único evento, e o livro é extremamente enxuto. A concepção do tempo/espaço do primeiro romance mimetiza a gestação das ideias revolucionárias e a construção de uma perspectiva utópica, a do segundo, a urgência das ações e a deformação e o retrocesso do imaginário das esquerdas nacionais.

O que está, porém, por detrás de todas as problemáticas que os romances propõem é a urgência de decifrar o Brasil. Em Quarup, há o reconhecimento da necessidade de 'descobri-lo', de conquistar o seu centro geográfico, e há a transição do protagonista por entre os diversos tipos sociais. Em Bar Don Juan e, principalmente, em Reflexos do Baile, o Brasil está encoberto pelo véu negro da ditadura, a identidade nacional corrompida pelos gritos de dor dos oprimidos e o povo, mergulhado no mais profundo silêncio.

Em Reflexos do Baile os diplomatas ignoram a nação em que vivem, os policiais carecem de uma linguagem menos truculenta para lidar com os homens e os revolucionários, de uma aproximação maior com a população. Exemplo disso é a figura da empregada, que, representando o povo, é

\footnotetext{
${ }^{1}$ A extensão de Quarup foi um dos aspectos mais explorados pela, nas palavras de Glauber Rocha, 'intelectualidade pseudo-sofisticada' para 'esculhambar' o romance. Lígia Chiappini faz um valioso cotejo entre as diversas opiniões sobre Quarup, quando da sua publicação, o que permite uma melhor compreensão da recepção do livro pelo público leitor da época: "Comparando o livro de Callado com Pessach, a travessia, de Carlos Heitor Cony, publicado no mesmo ano, os dois críticos (Nelson Werneck Sodré e Paulo Hecker Filho) ressaltam a temática comum ( a revolução brasileira) e consederam o livro de Cony mais bem realizado literariamente, porque mais conciso, ao contrário de Quarup, que seria excessivamente grande, sobrecarregado de fatos e idéias, inverossímil." (Op. Cit. p.130)
} 
desprezada pelas autoridades que pouco ou quase nada aproveitam do seu depoimento, e pelos revolucionários, que esquecem, sem comida e sem bebida, trancafiada em seu quarto. Joselina Galantim Pereira não compreende o comportamento do seu patrão, seu Rufino, e não consegue penetrar nas motivações que levaram o jardineiro, Válter, a empunhar uma pistola:

"Então Seu Rufino foi na cristaleira apanhar dois copos e uma garrafa de bebida e eu disse a ele para deixar que eu pegava a ele então falou estrangeiro comigo também. Aí me deu uma esquisitice, não sei porque fiquei nervosa, com vontade de chorar, até me desgrenhei um pouco, o senhos desculpe, distraída dos papelotes que saiu uma porção na minha mão, e quando comecei a fungar e a soluçar de engasgo na gola da camisola. Seu Vítor me disse que eu podia ir para o meu quarto mas ele trancou a porta pelo lado de fora e só me abriu no dia seguinte para eu fazer café para todos.” (p. 108)

O olhar míope com que os policiais, embaixadores e revolucionários vêm o povo é o mesmo com o que vêm o Brasil. A dificuldade de compreender os anseios populares é o reflexo da impossibilidade de enxergar o Brasil real, concreto, e, consequentemente, de construir um projeto viável para a nação. Os guerrilheiros que pretendiam fazer uma revolução popular, amarguram a distância entre o que realmente acreditavam e o que se impunha diante da situação nacional. Dirceu, Vítor, Juliana, Amália, Mejia, Bernardo, Válter e Valdelise, todos foram presos e submetidos a sessões cruéis de tortura sem que nenhum deles soubesse o porquê de tudo aquilo e em nome de eu seus sonhos e suas vidas estavam sendo sacrificados. 
A influência da política norte-americana no Brasil marca todo o desenvolvimento de Reflexos do Baile e evidencia o confronto entre duas realidades brasileiras absolutamente distintas, já exploradas nos romances anteriores: a moderna, fruto do projeto de Brasil das elites, que marginaliza todos os menos privilegiados e abafa os seus anseios, e a arcaica, consequência óbvia do abandono a que a maior parte da sociedade fora submetida para assistir ao sucesso dos planos políticos no Brasil moderno.

A esquerda abriga este segundo Brasil e deseja propor um projeto nacional e popular, eu resolva suas contradições. Porém, esse projeto, lamentavelmente, não dialoga com a população, analfabeta e miserável, exatamente porque não consegue oferecer respostas para as suas verdadeiras necessidades e desejos. Beto trai sua classe, como Juliana, e renega seu cargo na polícia. Porém, ao ingressar no movimento revolucionário e conviver com a população miserável da cidade, suspeita da distância insondável entre as intenções da esquerda de acumular armas para sobreviver à luta contra a ditadura e a necessidade de comida eu assola o país:

"Dirceu: Eu sou um traidor convicto mas pretendo eu a traição dê frutos e aqui não dá. Não dá mesmo. Só se em vez de gente eu fosse um boi, uma manada de búfalos, um churrasco. Você me fala em armas, mais armas, mas eu preciso de costelas, patinho, acém, chã-de-dentro e mocotó. Tenho uma grosa de guerreiros e até um santos ou dois mas não conseguimos vencer a mansa resignação dos eu não comem. A menos que rebente uma guerra não vejo quando é que teu trem lacrado vai entrar apitando para desovar na plataforma o traidor. Não pense eu estou lambendo minha própria ferida não que eu tenho o estômago forte e faço três refeições por dia." ( p.17) 
Reflexos do Baile propõe um olhar mais crítico sobre a questão da identidade nacional, pois reafirma a urgência de a população compreender a imagem real, concreta, do Brasil, sem reinventá-la, mascará-la, escondê-la. O Brasil é tal qual o seu povo, miserável, ignorante, doente, esta é sua identidade e a partir dela é que as propostas de transformação deverão surgir. O centro do Brasil é aquele com que os expedicionários de Quarup depararam-se em meio à floresta Amazônica, um imenso terreno abandonado e ameaçador, onde fervilham as mortais saúvas negras e em torno do qual choram os indígenas de fome, de dor:

“A América Latina não gosta do nome que tem porque não gosta de ser aquilo que é. São países que se consideram, todos e cada um, em eterna formação e em busca de uma identidade. Como já disse não sei quem, todos eles sabem muito bem a identidade eu têm - mas não gostam dela. Preferem, por isso, fingir que ainda não têm nenhuma."1

Ignorar a verdadeira figura do Brasil, como fizeram os expedicionários, ou deixar-se sugar por ela, como fez Fontoura, é morrer nas águas turvas da vida, como João, e amargurar a mais trágica aventura dos brasileiros, como Vítor.

A problemática apontada em Reflexos do Baile acaba por desvendar as intransponíveis dificuldades encontradas pelos revolucionários para realizar a revolução. Dificuldades que eles mesmos jamais poderiam decifrar em meio

\footnotetext{
${ }^{1}$ Callado, Antônio. “A América Latina é hoje nau de insensatos”. In: Crônicas do Milênio. Org. Martha Viana. São Paulo, Francisco Alves, 1997. (p.90)
} 
às artimanhas da repressão, já que a utopia das esquerdas desmanchou-se por entre os ocultamentos da História nacional.

Toda a tragédia que Reflexos do Baile traduz, em forma e conteúdo, não anula, porém, a esperança do autor no futuro do Brasil. Prova disso é a publicação mesmo do livro, que grita para que este terrível episódio da nossa história não seja esquecido e borra a tinta com que o governo vinha escrevendo a memória da nação. Reflexos do Baile é não apenas a história do fim da utopia eu queria vencer o autoritarismo com armas e com sangue, através da luta armada, mas também é a mais lúcida lembrança de que é preciso sonhar para que os homens ganhem contornos firmes e existam, e de que é possível, sempre, burlar o poder opressor e fazer crescer a voz rouca dos oprimidos.

É isso o que Callado faz através de seus romances, pedaços que são das nossas frustrações, consciente da necessidade de olharmos o nosso retrato terrível para, pouco a pouco, irmos limpando as nossas deformidades. Callado não desiste deste ofício, é antes o verdadeiro utópico, que não perde a fé na força das suas palavras e que se empenha para nos ajudar a conhecer o Brasil e a construir a nossa memória histórica. Nasce, então, o quarto romance, Sempreviva, para não deixar eu as cicatrizes escamoteiem o passado, pois é ele eu nos guiará para a construção de uma nova utopia. 
4. O hino às avessas: Sempre Viva, "o romantismo da desilusão"

“(...)Que se constrói? Um texto ou um percurso? A intenção de um lado, resposta vaga, moral herdada. Do outro lado o curso da palavra, da resposta, o som e o gesto seguidos um ao outro, um som que aponta a um gesto que exige um som liberto, e o acto assim é já um bolbo de intenção segura, à revelia da emoção primeira.

Assim o gesto, quero dizer, em texto. Organizar o gesto como se fosse um texto. Aliterar os actos, Rimar, quando convém, o gesto e a intenção que se tributa ao rasgo. (...)" (Ruy Duarte de Carvalho, em Hábito da Terra - poesia) 
Publicado em 1981, Sempreviva busca investigar o que pensam e sentem os homens que participaram ativamente dos governos repressivos das décadas de 60 e 70, seja os que abusaram do poder opressor, seja os eu lutaram contra ele.

O último dos quatro romances em que Antônio Callado resgata o período ditatorial, iniciado com o golpe de 1964, tem como eixo a história de Quinho, um exilado, que retorna ao Brasil ainda antes da abertura política, ajudado por Pepe, por Iriarte e, especialmente, por sua filha, Jupira, todos eles comunistas, mas que viviam como contrabandistas.

O protagonista entra em Corumbá sob a orientação da Anistia Internacional de Londres com o objetivo de recolher provas contra os policiais que, mesmo escondidos da morosa justiça brasileira, continuavam a exercer ações bárbaras e cruéis. O que Quinho quer verdadeiramente, porém, é encontrar esses policiais não para render as multidões que eles torturaram, mas tão somente para vingar-se do assassinato da sua ex-amante, Lucinda.

Quinho encontra os dois grupos antagônicos que convivem na Cidade de Corumbá, o dos policiais e o das pessoas ligadas ao Partido Comunista, ambos forçados, por motivos diversos, a viver na clandestinidade. Os primeiros, porque viram-se obrigados a sumir do cenário nacional, a fim de escaparem das acusações contra os selvagens assassinatos que cometeram, pois, finalmente, começaram a vir à tona, devido à pressão dos movimentos pela anistia do Brasil e, principalmente, no exterior ${ }^{1}$; e os segundos, porque,

\footnotetext{
${ }^{1}$ Os movimentos pela anistia fortalecem-se a partir de 1978, quando os grupos nacionais e os exilados políticos conquistam uma organização eficiente e quando a crise econômica brasileira divide o acordo das elites, evidenciando a crise política pela qual a nação passava: "Não conheço em todo o período de militância na denúncia da ditadura brasileira no Exterior nenhuma palavra de ordem que tenha unido tanto quanto a anistia. De repente, e pela primeira vez, sentávamos todos juntos: democratas liberais, cristãos, pessoas com tendências socialistas e mesmo os comunistas (...) Nós achamos muito mais do que uma palavra de ordem. Achávamos um modo de
} 
além do perigo - apesar de tudo, ainda presente - de caírem nas garras do aparelho repressor, tinham como missão, encomendada pelo Partido Comunista, encontrar os torturadores que se escondiam e se disfarçavam, para, enfim, leva-los a julgamento.

Policiais e comunistas forjam ardilosamente as suas máscaras e impedem que suas identidades verdadeiras sejam descobertas pelo inimigo. $\mathrm{O}$ delegado Claudemiro Marques, cujo pseudônimo é Antero Varjão, e os seus subordinados, assumem atividades de fazendeiros e caçadores, o médicolegista, Ari-Kunt, oculta-se por trás da máscara de Juvenal Palhano, pesquisador e admirador da natureza, enquanto os militantes de esquerda apresentam-se como contrabandistas.

Embora os grupos não se identifiquem socialmente, eles não abandonam as atividades que realizavam durante o período mais crítico do fechamento da ditadura militar no Brasil. De um lado, há a continuidade do trabalho dos policiais, que, mesmo longe das delegacias, torturaram e matam pessoas, prática que estendem, aliás, aos animais; e do outro lado, há a trama, decida cuidadosamente, do Partido Comunista, que, em meio à dor e à indignação, abriga uma incansável resistência contra a ditadura.

A construção dos disfarces e a sua quase perfeita adaptação aos rostos dos personagens impedem a manifestação da tolerância, do ódio e dos ressentimentos que, no auge dos anos do terror, definiram a relação entre revolucionários e policiais.

A administração dos conflitos assim colocada faz da narrativa um jogo de falsas imagens e interesses ambíguos, como vimos acontecer já em Reflexos 
do Baile. Esse jogo, em Sempreviva, estende-se aos policiais, eu têm suas almas adentradas pelo olhar atento do narrador.

Quinho embrenha-se em Corumbá para tentar iluminar a mata escura e dissimulada do interior do país. A sua presença quebra, como veremos, o frágil equilíbrio que se estabelecera no convívio entre caçadores e contrabandistas, pois o protagonista passa a perseguir com obstinação - e temor - a verdadeira identidade daqueles que assassinaram sua excompanheira, Lucinda.

Dividido em três partes, 'Regresso à chácara materna', 'O dia da caça' e 'A deusa arrumadeira', o romance explora os conflitos interiores vividos, de um lado, por Quinho, Jupira e sua filha, Hera, e, de outro, pelo delegado. Claudemiro Marques. A narrativa também problematiza o universo interior do médico-legista, Ari-Kunt, e a condição em eu se apresenta Lucinda, A deusa que comanda a arquitetura de toda a trama ficcional, caótica e irônica.

Documentar as atividades que Claudemiro Marques e seus capangas desenvolvem e descobrir sob que máscara vive o médico legista Ari-Knut (já que o disfarce utilizado pelo delegado fora cuidadosamente desvendado por Jupira) é o desafio de Quinho e é o fio condutor da narrativa, que acompanha os pensamentos e sentimentos desnorteados do protagonista e dos outros personagens.

Logo nas primeiras páginas, quando Quinho, ou Vasco, atravessa a fronteira entre a Bolívia e o Brasil, revela-se a tensa relação entre o protagonista e a sua terra natal. Atraído e amedrontado, o protagonista resiste ao 'furacão autofágico' em que se transformara o solo brasileiro depois de ter sugado a sua amante para os porões do Dopes: 
"Resistindo tenaz à sucção do Brasil, que aumentava, forte com um tufão que a si mesmo se chupasse num sorvo, num silvo ensurdecedor, Quinho, vivendo agora seu pesadelo com os olhos secos e abertos, foi sugado rumo à fronteira, tentando se agarrar a tudo que fosse árvore quéchua ou poste de iluminação aimará, mas desgraçadamente leve demais, esvaziado do próprio peso, fardo de paina, criança em berço de vara, de vime, restituída, soprada de volta à floresta pública, à chácara materna" (p. 13)

A terra natal é, para o protagonista, mãe e madrasta, pois traz consigo o amor e o carinho registrados nas lembranças de uma infância idealizada, ao mesmo tempo que, corrompendo essas lembranças, traz a dor e o horror da morte de Lucinda, mulher que carregava o seu filho no ventre, perdido, para sempre, nos escombros do terror.

A morte infiltra-se por todos os poros de Vasco e pulsa intensamente num canto escuro de sua memória, em moto perpétuo, impedindo-o de desprender-se do profundo sentimento de culpa que a morte da excompanheira lhe causara e de restabelecer a sua vida.

A imagem de Lucinda sendo levada pelos policiais da sala de cinema para a sala de tortura acorrenta Quinho a seu passado. Ele se ressente por ter fugido nos trilhos do trem do Rio de Janeiro ao invés de ter tentado, como se fosse possível, evitar que a companheira fosse mais uma das vítimas da violência dos governos ditatoriais:

“- Eu estou sempre preocupado em libertar Lucinda.

Jupira ficou um instante parada. - Libertar? Como assim?

- Bem, quero dizer, expondo ao mundo, em toda sua feiúra, Claudemiro Marques, vulgo Antero Varjão, e o dr. Ari Knut, que é provavelmente o falso capataz e administrador Melquisedeque, é como se restabelecesse- 
mos, no cinema, o instante da queda do copo, que nunca chegou ao chão e eu se liga diretamente ao episódio e ao instante exato da prisão, eu permanece, de Lucinda." (p. 25)

A presença de Lucinda na vida de Vasco é tão imperiosa que o espanto de Jupira diante das explicações eu ele lhe dá para tentar justificar seu estranho comportamento é o mesmo eu nós, leitores, temos ao ler as primeiras páginas do romance, nas quais é relatada uma ardente relação sexual entre Quinho e Lucinda, seguida de um tenso diálogo em eu ela exprime o desejo de acompanha-lo a Corumbá:

“-Você primeiro prometeu que não vinha, que ficava à espera, lá de longe, depois prometeu, até ontem, até agora, agorinha mesmo, quando eu já estava dentro de você, que ia confiar em mim, que ia me deixar agir sozinho, inclusive para não me amar demais, não me esgotar. Ia ficar do lado de cá da fronteira enquanto eu te desagravava para que você recuperasse a liberdade - e o sossego - e eu de minha parte pudesse entrar num cinema com naturalidade, e viajar num trem noturno da Central. O quê? Fala mais alto. Eu sei, meu bem, eu sei que deixei escapar tua mão da minha mão e que... Não, lágrimas não, não é o caso. Não se fala mais nisso, pronto. Vamos atravessar juntos a fronteira para o Brasil, para Corumbá...’(p.p 14 - 15)

A todo momento Quinho dialoga com Lucinda num infernal embate de sentimentos e só com o desenrolar dos eventos é dada ao leitor a possibilidade de perceber que o protagonista, através dos recorrentes sonhos que tem com a companheira morta, experimenta as suas ações e reações como se ela estivesse no mundo dos vivos.

Ao longo da narrativa, não há passagem em que o protagonista deixe de evocar a ex-amante, de seguir seus conselhos - que, muitas vezes tornam-se 
em ameaças - , de ouvir sua respiração, de entender o seu ciúme. É como se Quinho vivesse em um sorumbático estado de vigília, conduzido pela sombra onipresente de Lucinda.

O protagonista, submerso em seu universo íntimo, mantém-se preso ao passado e alienado das transformações da realidade. Sempreviva persegue os discursos que se multiplicam na intimidade de Quinho, mimetizando o caos absoluto em que ele se encontra.

A estrutura da narrativa imita o tortuoso fluxo de consciência ${ }^{1}$ de Quinho, que gira, contínuo e imutável, em torno do momento da prisão da Lucinda. Os pensamentos e sensações do protagonista desdobram-se em círculos mal traçados e compõem um labirinto que só apresenta uma única porta de saída, a vingança contra o delegado e o médico-legista.

O labiríntico universo de Quinho lembra um tipo clássico distúrbio mental descrito por Freud $^{2}$, o qual se caracteriza pela impossibilidade do homem em aceitar novas percepções do cotidiano e por repetir sempre um mesmo padrão de pensamento - e de sonho -, preso que está a fixações geradas por alguma grande frustração vivida no passado.

Essa descrição de Freud traduz a disposição interior do protagonista para a vida, que parece querer manter-se no mais profundo estado de vigília. Os mundos, interior e exterior, existem, para Quinho, em função da reelaboração

\footnotetext{
${ }^{1}$ Moraes Leite, Ligia Chiappini. O foco narrativo ( ou A polêmica em torno da ilusão). São Paulo, Ática, 1989. (p.p. 25 a 62)

${ }^{2} \mathrm{Na}$ amência de Meynert - uma confusão alucinatória aguda constitui talvez a forma mais extrema e notável da psicose - o mundo exterior não é percebido de modo algum ou a percepção dele não possui qualquer efeito. Normalmente, o mundo externo governa o ego por duas maneiras: em primeiro lugar, através de percepções anteriores, as quais, sob a forma de um 'muno interno', são uma possessão do ego e parte constituinte dele. Na amência não apenas é recusada a aceitação de novas percepções; também o mundo interno, que, como cópia do mundo externo, até agora o representou, perde sua significação (sua catexia). O ego cria, autocraticamente, um novo mundo externo e interno, e não pode haver dúvida quanto a dois fatos: que esse novo mundo é construído de acordo com os impulsos desejosos do id e que o motivo da frustração parece intolerável." ( Freud, Sigmund. O ego e o id e outros trabalhos. (Obras Completas, vol. XIX). Rio de Janeiro, Imago, 1976.
} 
contínua do momento exato da partida de Lucinda, identificado com a cena do filme a que assistiam, ' $\mathrm{O}$ ano passado em Marienbad', de Robbe-Grillet e Alain Resnais, quando um copo começa a cair no chão. Porém, Quinho não vê completar-se a queda do copo, que permanece no ar, flutuante e incerto, como a sua própria vida:

“(...) cada ver mais tudo na vida estava lhe acontecendo feito uma representação, uma imagem de outra coisa. Ele bem que reagia, dava de ombros, virava a cara e prendia a respiração, mas o que não podia era negar a dificuldade cada vez maior que sentia de saber o que era a voz e o que era o eco, o que de fato acontecia ou apenas repetia o que acontecera ( isso naturalmente tornava o acontecimento antes um mero ensaio e rascunho e não o fato real) ou que relação estabelecer entre caos de vidro encontrados no chão e o copo, aquele copo retido no ar.” (p.92)

A lacuna entre o início da queda e o estilhaçamento final do copo é a que Quinho busca preencher, revivendo essa cena, do filme e da sua vida, em cada outra situação que se lhe coloca. O fluxo de tempo da vida de Vasco fora retido, como o copo no ar, e isso não lhe deixa perceber os passos que dá em direção à morte no terreno pantanoso e traiçoeiro da cidade de Corumbá.

O protagonista está irreversivelmente atado ao signo da morte, à esterilidade da terra, e totalmente incapaz de imaginar um tempo mais fecundo. A utopia, neste romance de Antônio Callado, torna-se um mero conceito soterrado pelas experiências do passado, já que Quinho não consegue projetar um futuro nem para si, quanto mais para a coletividade. $\mathrm{O}$ protagonista de Sempreviva não interage com a realidade e a sua trajetória traduz a sensação de que a história já fora acabada e de que nada alterará o 
seu curso, ao contrário de Quarup, que narra a longa aprendizagem de Nando, sustentada, ao final, pela confiança na possibilidade de os revolucionários, através da luta armada, interferirem na história nacional.

A vingança de Quinho não representa uma tentativa de mudança no contexto histórico nacional, mas tão somente a libertação de si mesmo, da sua história pessoal, mais concretamente, da sua culpa por não ter interferido na história de vida de Lucinda, ainda que ambos, sabidamente, tenham vinculado seus destinos aos movimentos revolucionários da esquerda.

O assassinato de Lucinda não representa, absolutamente, o seu fim, ao contrário, como o copo e como a vida de Quinho, a sua morte está suspensa no ar, inconclusa, aguardando o dia da desejada vingança para que se restabeleçam as relações entre os fatos e que se recomponha o passado através do presente, para, então, existir o futuro. Só assim Lucinda poderá partir definitivamente:

“(..) ou se tratava apenas, e simplesmente, de enfrentar uma insônia causada pela promessa, que a si mesmo fizera, de ir pela manhã á fazenda da Onça sem Roupa, ou La Pantera, como a chamavam os bolivianos, de Claudemiro Marques, vulgo Antero Varjão? Ia ver pela primeira vez, cara a cara, o homem que até hoje mantinha Lucinda em pena e aflição, homiziada na força dele, Quinho, de homem vivo, em seu coração, encapsulada em seus testículos, para não continuar suspensa entre o céu e a terra." (p. 30)

Estagnadas as histórias pessoais, a própria História do Brasil paira no limbo. Embora os comunistas tentassem fazer justiça contra os torturadores e alguns movimentos sociais procurassem se reorganizar, o país remoía o 
enfraquecimento moral e ético das relações humanas, contemplando, horrorizado, as águas podres que engoliram os brasileiros.

Nada acontece em Corumbá, nenhuma notícia dos arredores ou do resto do país chega a mobilizar os ânimos da população. Comunistas e policiais, na tocaia, espreitavam o inimigo e aguardavam o desfecho do período do terror, que parecia querer ver o seu fim com a abertura política elaborada pelo general Golbery do Couto e Silva ${ }^{1}$.

A estruturação do romance plasma, ao mesmo tempo, o caótico movimento dos pensamentos e emoções de Quinho ( e também de Jupira, de Herinha e de Claudemiro Marques ) e a perturbadora sensação de estagnação do processo histórico brasileiro. Ao lado das conturbadas subjetividades dos personagens, está a paisagem de Corumbá, árida, seca, sólida. A natureza descrita reproduz a estagnação social e política do país e a resignação a que se rendeu a maior parte das pessoas, para, afinal, sobreviver:

\begin{abstract}
“(...)Alguma coisa devia estar para acontecer se uma rua noturna arquejava assim, prostrada pelo calor debaixo de palmeiras carandá tão imóveis que, vistas de baixo, pareciam ter as palmas marteladas, damasquinadas à moda toledana no céu e não soltas e livres no espaço.” (p. 57)
\end{abstract}

O tempo do romance é fragmentário devido à superposição dos discursos interiores e, ao mesmo tempo, é refreado pela conduta do protagonista (que se mantém, como vimos, preso ao passado) e pela ausência de expectativas e inércia social que perpassa todo o texto.

\footnotetext{
${ }^{1} \mathrm{O}$ processo de abertura política correspondeu, em princípio, a um projeto dos militares, limitando-se a uma descompressão tutelada. Ao longo dos anos 80, no entanto, os desdobramentos deste processo ultrapassariam sua própria capacidade de controle.” (In: Mendonça, Sônia Regina de e Fontes. Virginia Maria. História do Brasil Recente. 1964 - 1992. São Paulo, Ática, 1996 - p. 87)
} 
A construção da narrativa a-linear subordina-se, por isso, à contenção do desenvolvimento do enredo, o que cria a atmosfera densa e irônica que domina quase todo o romance, já que a trama policial de Sempreviva - a vingança de Quinho - submete-se a uma morosidade que acaba por contaminar o conflito central. Só ao final, quando Quinho, finalmente, põe em prática o seu plano, o tempo transforma-se e acompanha um turbilhão de imagens narradas em uma ordem que busca restabelecer a cronologia e linearidade dos fatos, criando, ai sim, uma atmosfera condizente aos romances policiais tradicionais.

Assim como o protagonista fecha-se em seu universo interior e fica cego para o destino que lhe é reservado, o leitor perde-se em meio à estrutura labiríntica de Sempreviva e não enxerga as armadilhas da narrativa. Como em Reflexos do Baile, narrador e leitor compactuam na árdua tarefa de desvendar o lado oculto dos personagens para tornar possível a compreensão dos mecanismos das histórias, ficcional e brasileira ${ }^{1}$.

Tornar-se, portanto, fundamental acompanhar os processos que se dão no desenrolar da narrativa, os quais repetem os processos de um tratamento psicanalítico: para chegar às verdades dos fatos é necessário decodificar informações distorcidas pelo consciente dos homens e compreender as obscuras mensagens registradas em cantos quase impenetráveis da mente

\footnotetext{
${ }^{1}$ Flávio Aguiar discute essa questão no artigo "Visões do Inferno", publicado na Revista do Brasil, n. 4: 'Não é necessário grande esforço para se perceber, como constante em nossos processos culturais, a visão de um mundo ínfero, confuso, fragmentário, arcaico, anacrônico, paródico, ou outro adjetivo com que se queira iluminar tais paragens, de onde se deseja sair ou onde é necessário penetrar em busca da contemplação epifânica de algum segredo oculto que revelará, de fato, nossa verdadeira natureza. Aí se ajuntam, num redemoinho, ocas e senzalas, a lama que persistia na rua do ouvidor a afrancesada, o silêncio irredutível dos derrotados em Canudos, os doze pares de França que na guarda de honra de beata do Contestado viram vinte e quatro (dois Rolandos, dois Oliveiros, e assim por diante, já que eram pares), as veredas pactárias do Grande Sertão Veredas, a alma de pedra de Bibiana de Mesquita em $O$ que é isso companheiro?(...)"
} 
humana. Em Sempreviva, o 'inferno são os outros' e, penetrar nesses 'outros', significa ter de destruí-los para reconstruir uma história capaz de romper com as torturas do passado.

Depois do assassinato da companheira, Quinho nunca mais atingira o clímax de um ato sexual livre da imagem do corpo nu da morta. Lucinda é a súcuba, como a vê Jupira em um acesso de ciúme de Quinho - demônio feminino que vem pela noite copular com aquele que deveria ser o seu homem, perturbando-lhe o sono e causando-lhe pesadelos - e é a sibila mulher que coloca Quinho em contato com o sobrenatural, com o mundo dos mortos, predizendo os dias do seu ainda companheiro e amante. Bruxa e deusa, Lucinda é a força que domina o destino do protagonista, fazendo dele um servo fiel e temeroso:

\footnotetext{
“-Por isso é que o escuro do cinema prolongava não apenas a alcova geral da nossa vida, o túnel silencioso em que a gente flutuava e rolava, mas, da mesma forma, a alcova de minutos antes, a cama onde os travesseiros tinham ficado úmidos de suor e o lençol de esperma. O me arrancarem Lucinda dos braços me pôs, digamos assim, na romaria, na peregrinação, para reatar, não no plano físico, é lógico, mas no de uma libertação que me é exigida, aquele momento que ficou, de uma forma literal, no espaço, feito um copo que vai se estilhaçar no chão mas lá não chega, gestos e copos e cópulas sem consumação (...)” (p.p 72-73)
}

Lucinda representara, para Quinho, a ponte entre a sua intimidade e a realidade brasileira, o que o levou a engajar-se na luta contra a ditadura. A terrível morte da amante significa a obstrução da passagem de Vasco de um lado da ponte para o outro, condenando-o a viver em uma das extremidades, a da sua subjetividade. $\mathrm{O}$ seu universo interior transforma-se em um labirinto 
povoado por cobras e lacraus, por Aris-Knuts e Claudemiros Marques, transforma-se em sua própria armadilha.

Nessa medida, radicaliza-se o imenso abismo existente entre mundo interior e a realidade vivida ${ }^{1}$ já observado em Quarup, Bar Don Juan e Reflexos do Baile. Os acontecimentos exteriores nada comunicam a Quinho, o que faz com que suas ações subordinem-se tão somente a seus desejos e frustrações interiores. O herói de Sempre Viva, diferentemente dos personagens dos outros romances, não acalenta nenhuma expectativa de ter sua vida melhorada por transformações sociais, pois ele enxergava apenas os seus conflitos interiores. A construção de Quinho corresponde, nessa medida, ao herói do 'romantismo da desilusão', descrito por Lukács na Teoria do Romance ${ }^{2}$.

“(...) já se não trata aqui de um a priori abstracto em face da vida, que pretenda realizar-se por actos e cujos conflitos com o mundo exterior forneçam ao romance a sua efabulação, mas antes de uma realidade puramente interior mais ou menos acabada e rica em conteúdos que entra em concorrência com a do exterior e que possui em si própria uma vida rica e movimentada, e se considera, na sua espontânea confiança em si mesma, como a única verdadeira realidade, como a própria essência do mundo, constituindo o seu fracasso na tentativa de tornar efectiva essa adequação, o objeto mesmo da narrativa."3

Esse tipo de herói define Quinho, uma vez que ele não desenvolve uma trajetória que busque fundir subjetividade e realidade ('romance da

\footnotetext{
${ }^{1}$ Lukács, George. Op. Cit. (p.p. 129-130)

${ }^{2}$ Idem, ibidem (p.130)

${ }^{3}$ Idem, ibidem (p.129)
} 
aprendizagem' ), como o faz Nando e Laurinha, e tampouco uma trajetória em que seu universo interior concorra com o exterior, para impor-se sobre ele ( 'idealismo abstrato' ), como o faz João. Quinho é, antes, um herói que tem a alma "mais ampla e mais vasta do que todos os destinos que a vida pode lhe oferecer ${ }^{1}$ e, por isso, está absolutamente voltado para si mesmo:

\begin{abstract}
"Assim, enquanto que a estrutura psíquica do idealismo abstracto se caracterizava por um excesso de atividade, manifestada para o exterior e que nada podia entravar, encontra-se muito mais aqui uma tendência para a passividade, a tendência para se esquivar de preferência a assumir os conflitos e as lutas exteriores, a tendência para acabar, dentro da alma e pelas suas próprias forças, com tudo o que a pode afectar."2
\end{abstract}

A ligação entre a interioridade do herói e o mundo torna-se amorfa e atomizada, destituindo a vida de qualquer sentido e significação. As profundas fissuras abertas na alma de Vasco rompem os antigos vínculos com a realidade, o que o faz perder a capacidade de acreditar até mesmo nas ações individuais como meio para a transformação do mundo. A realidade perde, então, 'qualquer simbolização épica', e o herói mantém-se, diante disso, passivo e em absoluto estado contemplativo. Esse é o herói do 'romantismo da desilusão'.

Lucinda, apesar de não representar mais a ponte entre a subjetividade do protagonista e a realidade, passa a ser a ligação entre outros dois mundos, o mundo dos vivos e o mundo dos mortos. E é por causa do contato com esse mundo sobrenatural que o herói parte para a ação e mata Claudemiro

\footnotetext{
${ }^{1}$ Idem, ibidem (p. 131)

${ }^{2}$ Idem, ibidem (p. 130)
} 
Marques, abandonando o estado contemplativo que o caracterizara anteriormente.

$\mathrm{Na}$ galeria das personagens femininas que caracterizam a tetralogia de Antônio Callado, Lucinda ironiza o traço romantizado e idealizado de que as mulheres são dotadas em Quarup e Bar Don Juan. Embora, quando viva, ela represente a união entre intimidade e coletividade, e, depois de morta, a união entre o céu e a terra, a amante não inclui em seu projeto o outro, pois utiliza Quinho e Jupira para concluir a sua vingança e atropela as expectativas tanto da Anistia Internacional, quanto do Partido Comunista.

A proposta de Lucinda é mesquinha e individualista, uma vez que deseja apenas castigar aqueles que a assassinaram, não se importando, todavia, com aqueles que continuam resistindo contra a ditadura. Lucinda perde a perspectiva social e coletiva e nega o próprio imaginário político por que morrera. Longe de querer entender o esforço do Partido Comunista e da Anistia Internacional, Lucinda ironiza o movimento das esquerdas, pois sabe que a história não será transformada em favor dos oprimidos.

A força que impele Vasco a agir provém da ex-companheira, que o conduz ao confronto com o inimigo mesmo contra o seu desejo mais íntimo de restringir sua ação à idealização da vingança, à contemplação da imagem do delegado e do médico-legista mortos, projetas na realidade por seu universo interior.

Enquanto Lucinda procura motivar Quinho a vingar-se dos torturadores, Jupira ajuda-o a construir os meios para tanto, passando a ser, então, a sua ligação, ainda que frágil, com a realidade. Jupira torna-se, como observa Quinho inúmeras vezes, a sombra de Lucinda na terra. 
A identificação entre Lucinda e Jupira é, para Quinho, tão intensa que crê ver a morta na figura viva em diversas situações, como se lê nas primeiras páginas do romance, quando a filha do contrabandista Iriarte zela pela entrada do exilado no Brasil e garante a sua fixação em Corumbá:

"Foi num estado de pavor, cercado de símbolos ásperos e acerados, que lhe cortavam a cara e o peito e lhe lanhavam as mãos, quando tentava afastá-los - Nicodemos abrindo de par em par as coxas da mãe debaixo das pedras e da caliça do templo, que desabava, as colunas afastadas e desmembradas, de par em par, por um cego de cabelo aparado rente que Quinho finalmente, com a morta guiando o carro, ingressou de novo a terra do Brasil." (p. 21)

O envolvimento amoroso entre Quinho e Jupira dá-se na medida em que Lucinda manifesta-se, para o amante, favorável a essa relação. É ela quem controla o quanto Vasco pode ou não se entregar a tal paixão terrena. Lucinda chantageia-o através da fidelidade amorosa que ele deve a sua memória, mas não o impede de conquistar Jupira, pois ela é imprescindível na vingança tramada, tanto par ajuda-lo a identificar e desmascarar AriKnut e Claudemiro Varjão, quanto para animá-lo a sair do profundo estado contemplativo do mundo em que se encontrava.

Jupira, a partir do olhar de Quinho dispensa às duas mulheres, acaba por identificar-se com a morta. A comunista vê em Lucinda a sua irmã gêmea, dotada do poder de controlar o destino de Quinho e o seu mesmo, uma vez que pressente que ambos foram escolhidos por ela para agir sobre o mundo dos vivos.

O curioso, porém, é que Jupira, além de colar-se à imagem de Lucinda, compraz-se com a ideia de ter sido escolhida para servir a sua causa e, 
consequentemente, à causa de Quinho. Jupira compartilha a dor do protagonista, uma vez que também ela teve o noivo e pai de sua filha, Herinha, assassinado pela repressão e, timidamente, reconhece alguma nobreza nas suas intenções.

Ao apropriar-se dos anseios de Lucinda e de Quinho, Jupira incorpora o papel de instrumento do mundo dos mortos e associa-o ao papel que já desempenhava para o Partido Comunista, expressando a síntese final dos desejos dos homens, mortos e vivos, que sofriam com o ódio recalcado contra aqueles que cometerem as mais abjetas e truculentas ações sem que nada, ninguém, fizesse-lhes qualquer tipo de censura:

“-(...) Fale, lucinda, minha irmã, continuou Jupira, fale aí do seu jacente mirante onde você se vê viver sua pós-vida que viveu e para continuar a ser beijada nestes seios que você me legou, pois assim ele afaga e lambe quatro seios nos meus dois e nos possui as duas, vertendo em nós o espermacete quente. A verdade é que alguém tinha de beijar a boca que não diz o nome para que o mundo identificasse pelos gemidos o monstro, pois mesmo os monstros desferem a melodia que os denuncia quando, deixando de ser fera caçada, são apertados, como aquele viola da gamba, dos velhos azulejos da fazenda, entre as coxas da mulher amada.” (p.p 158,159)

A mãe de Herinha - menina que terá, igualmente, ao final do romance, fundamental importância nos planos de Lucinda - Aceita a onipresença da morta até mesmo nas suas relações sexuais com Quinho. Jupira reconhece ser ela mesma a ponte entre Lucinda e os que a torturaram e entre Lucinda e o próprio Quinho, a quem deve fortalecer moralmente e ajudar na árdua tarefa de superar suas fraquezas a fim de consumar a vingança contra Claudemiro Marques, vulgo Antero Varjão, e Ari-Knut, que se mantém, até 
os últimos momentos da narrativa, oculto por de trás da máscara de Juvenal Palhano, ironicamente, o bondoso amigo da família dos iriartes e também do protagonista.

Como agente do Partido Comunista, Jupira tece ardilosamente a sua aproximação com o fazendeiro Antero Varjão, com o qual chega a concretizar uma inesquecível relação sexual. A confirmação das suspeitas do Partido de que a verdadeira identidade do Onceiro era a do delegado Claudemiro Marques acontece num baile, quando Jupira identifica em seu pescoço a marca, quase desaparecida, de uma antiga cicatriz que ia da orelha esquerda à metade do pescoço. Esta era a prova cabal, e única, da farsa vivida pelo torturador, após as muitas cirurgias plásticas a que se submetera para esconder a marca que poderia iluminar o seu passado atroz.

Habituados a fazer esse tipo de trabalho para o Partido há mais de dez anos ( trabalho para, segundo Jupira, 'quem fica na luta, nas barricadas, no, em suma, Brasil', p. 139), o sobrado dos Iriartes, referência à casa dos comunistas/contrabandistas, ano a ano, procurava desmascarar os suspeitos, o que custava a Jupira, quase sempre, algum tipo de envolvimento íntimo com o inimigo.

A filha de Iriarte irrita-se, em várias ocasiões, porque sabe que o trabalho do Partido, que não raras as vezes conseguira fazer justiça contra os policiais foragidos, nada representa para Quinho. Ele busca, porém, justificar-se pelo fato de ter sido enviado pela Anistia, que teria restringido a sua ação a descobrir quem eram os desalmados caçadores e a desmascarar Antero Varjão e Ari-Knut, que todos criam ser um dos capangas de Claudemiro, o Melquisedeque. 
Claro está que o interesse de Quinho em Corumbá é bem outro. Mas Jupira não pode acusa-lo, porque, até para ela, o caso Antero Varjão tornarase especial há tempos, pois, além de pôr em risco sua vida, como sempre o fazia, põe, isto sim, a alma, que se deixara impregnar pelo prazer inadmissível - que lhe proporcionara o corpo do torturador:

“-Pequei, não nego, expiarei quando puder, tinha vontade de dizer (a Quinho), atrevida, mal-criada, afrontosa, já que ele, feito um rapazinho pálido, espinhento, ciumento, mal parecia interessado nos perigos que tal - vá lá - pecado, poderia ter tido, ou ter, em relação ao interesse maior, os do sobrado, para usar idéias do velho Iriarte (...) Quinho teria ideia do sofrimento que infligia, por cima do que ela a ela própria se infligia, cultivava, quase, temendo, antes de tudo mais, que, como um mal venéreo recolhido, ou veneno de lacrau...” (p. 138)

Jupira sente-se culpada por ter entregado-se ao Onceiro e declara, no diálogo que mantém com Lucinda, ter sido amada por ele. A comunista associa Claudemiro Marques al lacrau que um dia tivera que perseguir para deixar-se picar, a fim de descobrir qual era o tipo de veneno do bicho peçonhento e salva a filha, Herinha, a quem o escorpião primeiramente atacara.

Tempos depois, Jupira relata a Herinha a experiência que ambas tiveram com a intenção de fazê-la conhecer a sua própria história de vida e aliviar as angústias guardadas desde aquele época pelo temor de que a filha morresse. Porém, o resultado fora dramático, uma vez que Herinha, ao compreender que a sua vida fora devolvida pela quase morte da mãe, pressente as violentas relações do mundo. 
A reação de Hera impede Jupira de libertar-se da culpa de ter posto a vida da menina a poucos passos de uma fatalidade e acrescenta-lhe outra, a de ter desvendado as verdadeiras e perigosas relações entre vida e morte que os adultos tão bem conhecem, e que as crianças, felizmente, ignoram:

\begin{abstract}
"Agora, mirando a filha absorta, que quando inquieta, infeliz, buscava, talvez por culpa dela e da sua história, a companhia da lacraus, Jupira se perguntava, ainda uma vez, se não errara contando a Herinha o conto daquela noite na choça do posseiro, já que esse conto antigo, ela sentia obscuramente, a obrigaria a contar um dia à filha o segundo conto do lacrau, a segunda parte, que o Quinho também não queria contar, a história da segunda nudez nas trevas, do segundo leito onde os dois tinham se esponjado - era bem isso - até um fundo cansaço e imobilidade que tinham sido não um fim honroso de luta, como no conto um, mas, simplesmente, um rendição, uma entrega. Ao lacrao." (p. 177)
\end{abstract}

O discurso indireto livre revela os pensamentos obsessivos de Jupira, os quais dão vazão ao temor e à culpa cultivados por causa das picadas dos lacraus: uma real, que a torna heroica por ter salvo a vida da filha, e uma simbólica, que a torna íntima por ter contaminado as causas nobres do Partido com o prazer que desfrutara junto à figura monstruosa de Claudemiro Marques.

A imagem que Jupira alimenta de sí mesma não é a de mártir, como a sua atuação junto ao Partido e junto a sua filha poderia fazer supor, mas de um espírito portador de má sorte. Para Jupira, as pessoas a quem ama acabam vivendo no limite da morte, pois deixa-as, sempre, na iminência de sofrerem perdas irreparáveis. 
O assassinato do noivo, pai de Hera, pela repressão e a responsabilidade pelos acontecimentos da vida da filha fazem de Jupira uma parente muito próxima de Quinho, pois ela também revive de forma obsessiva e culposa as trágicas experiências do passado:

“(...) há pouco, muito pouco tempo atrás, tinha ela começado uma angustiante e enjoativa descida dentro de si mesma, sem dúvida por querer justificar, mas se emaranhando toda em idéias e conceitos que não tinha com quem discutir, e que, para dizer a verdade, não queria discutir nem consigo mesma. Quase cortara, aliás, relações com ela própria no instante em que, revendo o episódio do lacrau, pilhara-se dizendo que tinha sido salva pelo Mal, assim mesmo, com $\mathrm{M}$ grande, pois assim a palavra tinha aparecido escrita na sua imaginação, por incrível que pareça, um $\mathrm{M}$ vermelho em fundo amarelo. $\mathrm{O}$ veneno, a peçonhenta, essa Mal maiúsculo, nunca teria se dissolvido completamente, eis a questão, no seu organismo, permanecendo ao contrário nela feito um mal venéreo, recolhido mas atento, e se reativara, natural e muito convenientemente, quando ela..." (p.47)

Morte e vida encontram-se e complementam-se nos bichos peçonhentos, no lacrau que picou Hera e nas cobras que os Iriartes criam, assim como Bem e Mal misturam-se em Jupira. O veneno do escorpião permaneceu em seu corpo 'recolhido mas atento', até que, em seu papel duplo, fez com que ela se entregasse ao Onceiro. Também Claudemiro Marques é um lacrau, pois pica o corpo e envenena a alma da comunista, mas é por causa dele que Jupira torna-se, aos olhos dos outros, mais uma vez, a mártir das causas sociais. 
Jupira sente o veneno dos lacraus corroerem a sua vida e a dos que ama, mas sabe que, da mesma maneira, ela é o lacrau que marca os destinos de muitos dos Claudemiros Marques. Atenta e sorrateira, Jupira é a cobra que troca de pele para anunciar a morte de Antero Varjão e, sem sabe-lo, a do próprio amante, Quinho. Como o noivo, o delegado e o exilado compõe em uma única história o prazer e a dor.

Assumindo a sua vida dupla, a filha do velho comunista Iriarte crê ser, ao mesmo tempo, a portadora, para uns, da boa sorte, pois incorpora o papel da heroica vingadora dos torturados, e para outros, da má sorte, pois empurra as pessoas amadas para o mar da violência e do terror.

A culpa e o ressentimento aprofundam-se na alma de Jupira, quando percebe representar, para Herinha, a ponte entre o seu mundo inocente e o violento mundo adulto. É através da mãe que Hera pressente a inevitável convivência entre Bem e Mal. Primeiro, porque salvara a sua vida com o veneno mesmo daquele que lhe trouxera a morte e, depois, porque permitira que ela conhecesse o terrível destino que seu macaco e amigo, Pixuna, tivera nas mãos de Antero Varjão, maltratado e torturado até a morte.

O sentido maniqueísta da vida é rompido em Sempreviva. Antônio Callado explora na construção dos personagens os limites da solidariedade e do amor e os da traição e do ódio, todos eles fundamentais na composição dos personagens. Vida e morte, Bem e Mal, misturam-se na relação que os personagens mantém com o mundo e entre eles mesmos e, inseparáveis, perdem os contornos que os definem, já que, inevitável e continuamente, um nasce do outro. 
No inicio do romance, Hera aparece como um reflexo dos dramas vividos pela mãe, pois a sua existência está voltada para explicar o comportamento de Jupira e a sua história de vida. Com o desenrolar da narrativa, porém, essa personagem cresce e ganha complexidade, tornando-se, de maneira surpreendente, a protagonista dos acontecimentos finais

A primeira entrada de Herinha no enredo vem acompanhada pelo canto de Verdurino, canário tenor admirado e cobiçado por Juvenal Palhano, e pelo Jurupixuna, macaco que carregava um embornal a tiracolo cheio de milhos a fim de marcar o caminho de casa. Os três entram inesperadamente na sala em que Quinho conversava com Jupira, quando revelava a ela o seu aprisionamento a Lucinda.

A alegria presente no canto do canário e nos movimentos do macaco contrastam com a associação que Quinho, ao dar-se conta dos três, faz entre Hera e a 'criança de mármore que tinha ficado emparedada no ventre de Lucinda'. A projeção do filho morto no ventre da mãe pelos policiais em Hera evidenciam as características imperfeitas da filha de Jupira:

\begin{abstract}
"Quinho reparou, mirando com enlevo Herinha, que por sua vez fitava o tenorinho Verdurino, que os olhos dela, de um castanho líquido e luminoso, eram grandes, lindos, um claro mel - mas grandes talvez demais, não seriam? Rolavam um pouco nas órbitas, como se um sentimento de admiração, por exemplo, ou mesmo uma fixidez dinâmica, de contemplação, os fizesse girar um pouco, se moverem, como se move o sol e as outras estrelas?" (p.p. 28-29)
\end{abstract}

O comportamento de Hera enquanto o de uma criança excepcional é fortemente marcado no romance pelo olhar do 'outro', o universo da menina chega-nos deformado pela pena ou aversão que os adultos sentem por ela. Á 
exceção dos curtos diálogos que Herinha mantém com Quinho ou com seus animais de estimação, os seus pensamentos e sentimentos só se revelam livre da intermediação dos adultos, quando, ao final do romance, o macaco Pixuna some.

Nesse momento, a onisciência múltipla acolhe o desabafo das preocupações da menina com o destino de Pixuna e denuncia a falsa imagem que os adultos forjaram dela: a ingenuidade e a pureza atribuídas ao mundo da menina não correspondem à verdadeira relação que ela tem com a realidade que a cerca.

A intensa convivência entre Herinha e o macaco, o canário e a cobra Joselina proporciona-lhe uma harmônica integração com o mundo natural, a qual é confundida com a suposta impossibilidade de a menina lidar com o real.

Contudo, quando a narrativa penetra na intimidade da criança através de seus monólogos interiores ou mesmo das interpelações que faz à cobra, venenosa, Joselina, sobre o sumiço de Jurupixuna, desvela-se o quão profundo é o seu diálogo com a natureza e quanta sabedoria esta lhe propiciou adquirir para que se defendesse da violenta realidade:

"A mãe tinha lhe contado, uma trás da outra, histórias do pai dela, Herinha, histórias que, sem dizer nada, com a maior delicadeza, a menina deixava entrar por um ouvido e sair pelo outro, apesar da mãe repetir que era tudo verdade, que o pai tinha sido muito corajoso e mais isso e mais aquilo, que um dia ela ia saber muito mais sobre o pai e compreender tudo. (...) Pai, paizinho, era o fundo do quintal a todas as horas do dia, com o sol ou com chuva, e de noite também, com lua ou com vento, quando acontecia ela acordar e ouvir as árvores discutindo não sei o que e balançando a cabeça, nenhuma acreditando muito no que as outras di- 
ziam, ou pelo menos desconfiando, e era mais paizinho ainda de manhã cedo, com Joselina tocando o chocalho da cauda e Verdurino com aquele bico mágico que só ele mesmo tinha, catando o sol lá do fundo do horizonte, enquanto o convencido do galo, todo ancho, catava minhocas da terra." (p.125)

A inapetência de Hera para lidar, isto sim, com abstrações faz com que ela concretize as informações obtidas em uma infinidade de animais, insetos e plantas, os quais se transformam em excelentes interlocutores. Dessa maneira, Hera tenta desvendar nas curvaturas da pele que Joselina trocava onde estaria o seu amigo Pixuna. Para tanto, a menina chega a prometer à cobra venenosa que a levaria para passear na caixa do canário Verdurino caso ela a ajudasse a encontrar o macaco. Hera não sabia, porém, que iria cumprir sua promessa mesmo sem rever o macaco.

A cobra é, para a criança, a intérprete do mundo adulto, pois sabe que, como lacrau que a picara, Joselina é portadora da vida e da morte. Assim, com todos os sentidos alertas, Hera, na terceira parte do romance, ouve duas conversas da mãe, uma com Quinho e outra com Juvenal Palhano, e leva-as, essas e as outras histórias que conhece para a cobra costurar e oferecer-lhe uma solução.

Na primeira conversa que Hera escuta por de trás da porta, Quinho conta para Jupira que matou Claudemiro Marques para vingar a memória de Lucinda e a do Jurupixuna. Vasco detalha a morte reservada ao macaco, revelando à mãe e à filha que ele fora estuprado, torturado e pendurado como Cristo em uma Cruz e como um homem nos porões das delegacias.

Pouco depois, na segunda conversa, Hera ouve Juvenal Palhano revelar seu verdadeiro nome e oficio, Ari-Knut, o médico-legista. Também entende a 
ameaça que ele faz a Jupira de denunciar o verdadeiro responsável pela morte de Antero Varjão, Quinho, caso ela não lhe entregasse o maravilhoso canário tenor, Verdurino. A criança pressente que, mais uma vez, perderia ou o único amigo que lhe restara ou aquele que se tornara o seu herói vingador.

Hera, profundamente violentada pelo mundo dos adultos, decide, ela mesma, presentear Ari-Knut com a caixa de Verdurino, a qual continha não o melodioso canto do canário tenor, mas a picada mortífera da cobra Joselina:

"Sorrindo docemente, os olhos apenas um quase nada girando nas órbitas, Herinha estendeu, nas mãos, a caixa de chapéu, a oferenda, como a via Palhano-Knut, que, de joelhos depois de beijar Herinha na face, colocou seu próprio rosto contra a chapeleira, amoroso, para sentir palpitar do sabiá na gaiola de papelão, e, bem devagar, ouvindo à escuta, entreabriu a tampa da caixa." (p.p 287 - 279)

A doçura e a ingenuidade de Herinha, reforçadas por suas características de criança excepcional, contrastam com a sua capacidade de agir sobre o real de forma absolutamente independente contra aqueles que, direta ou indiretamente, agrediram-na. A escolha de Joselina, uma das cobras criadas pelos Iriartes, como arma de sua vingança e a frieza com que leva a morte àquele que, sob a máscara de Juvenal Palhano, era seu melhor amigo, surpreendem o leitor.

Também Hera foge ao maniqueísmo tão próprio aos discursos daquela época. Como a mãe, hera carrega consigo o veneno do lacrau, símbolo de vida e morte. A imagem da menina de inteligência 'abobada', como queria Antero Varjão, é rompida pela sua ação heroica ao interferir no curso da 
história da sua vida e, consequentemente, do romance, completando, para a satisfação de Vasco, a vingança de Lucinda.

Ironicamente, Herinha mostra ser muito mais decidida e corajosa do que Quinh ou Jupira. Os disfarces que Ari-Knut soube tão bem elaborar e que depois transformaram-se em ameaças paralisaram a ambos, aterrorizados pela sua competência em jogar com (e contra) os seus adversários. À Herinha, porém, a truculência do médico-legista representou o estímulo necessário para vingar-se dos seus opressores.

Quinho reconhece suas fraquezas e envergonha-se por não fazer jus à memória do seu trisavô, lanceiro do primeiro Batalhão dos Voluntários da Pátria. O protagonista, ao longo de toda a narrativa, busca identificar-se com esse seu parente e com outros heróis míticos, para produzir fagulhas de coragem em sua intimidade e finalizar o que tanto desejaram, ele e Lucinda.

Porém, como num jogo de espelhos, a imagem que o protagonista procura ter de si ao identificar-se a seres guerreiros e heroicos é contradita por suas ações cotidianas:

"Pensou, cabisbaixo, vencido, que, mesmo quando atende ao chamado, a coragem dos poltrões chega tarde e desleixada, ajeitando os chinelos, uma coragem relaxada, feito mulher que a gente finge que não conhece quando encontra na rua. Estava ao seu lado, a desmanzelada, mão fria no ombro de Quinho, enjoada dele como ele dela, cansada de ouvi-lo contar proezas do trisavô no Paraguai, manobrando um canhão La Hitte n.4”( p. 20)

É Quinho um herói dividido. Ao mesmo tempo que empunha a causa de Lucinda e faz dela a sua missão, tem o desejo íntimo de negá-la para poder novamente fugir desta terra marcada pelo signo da violência. A todo 
momento, Vasco ameaça desistir da vingança, mas logo recebe as palavras de Lucinda, que o desafiam e incitam-no a não mais ser o 'cavaleiro da irresolução' ou 'Involuntário da Pátria', como ele se mostrara ser até então.

Quinho vê-se condenado a oscilar entre os desígnios celestes de Lucinda e os seus fracassos terrenos. Ao protagonista faltam coragem e virilidade. Ele não consegue decidir-se por um projeto para a sua vida - tanto menos para a coletividade, absolutamente à margem do seu universo -, não consegue fazer o que gosta e nem deixar de fazer o que não gosta, não consegue concluir uma relação sexual.

A fragilidade do personagem é acentuada pelos tiques que possui e dos quais não pode libertar-se. Ora olhando a antiga cicatriz de um profundo corte na mão, ora desapertando o nó de uma gravata inexistente, Quinho encontra-se em uma condição mórbida, pois nem pode reverter o assassinato de Lucinda e nem aceita-lo.

A consciência de sua impotência e de seus repetidos fracassos, seja diante de uma relação sexual ou da vingança contra os policiais, está subjacente a todas as ações do herói, que se encontra aprisionado em um mundo de negatividades (Lukács), o que o impede de ter uma visão mais ampla de si e do mundo que o cerca:

“É o estado de alma romântico da 'desilusão que sustenta e apóia essa espécie de lirismo, uma exigência excessiva e super-determinada do que devia ser em relação à vida e uma clarividência desesperada quanto à vaidade dessa nostalgia, uma utopia que possui simultaneamente má consciência e que está antecipadamente certa da derrota. E nessa certeza, o elemento decisivo é que ela se conserva inseparável da cons- 
ciência moral, da evidência de que o fracasso é uma decorrência necessária da sua própria estrutura interna, de que é ela mesma, na sua melhor essência, no seu valor mais elevado, ferida por uma sentença de morte. Outrossim, tanto perante o herói como em face do mundo exterior, a sua atitude mantém-se lírica: amor e lamento, desolação, piedade, sarcasmo"

No dia em que o Onceiro e seus capangas partem para uma caçada, o protagonista organiza-se mentalmente para ir até uma das antigas senzalas da fazenda, a Pantenera. Aí espera encontrar e fotografar os cadáveres de algumas das vítimas, pessoas e animais, de Claudemiro Marques e de seus subordinados, que sabe estar lá por informes mandados por Liana, secretária, nos períodos vespertinos, da Anistia Internacional, e amante de Quinho. Assim conseguiria, enfim, provar as atividades bárbaras desenvolvidas na Pantanera e expor ao mundo o torturador, que promovia, além das caçadas terríveis, o tráfico de cocaína, torturas, estupros e assassinatos de pessoas que por lá se aventurassem a passar.

Neste dia, porém, além de o protagonista embebedar-se para conquistar a necessária coragem de que era destituído, deixa de ler a última carta de Liana, a qual continha a importantíssima informação de que Ari-Knut não se escondia sob a máscara de Melquisedeque, como todos, inclusive Jupira, acreditavam, mas sob a de Juvenal Palhano.

Quando finalmente Quinho interna-se na fazenda, chegam, saciados e alcoolizados, os caçadores-policiais. Entre o medo e a coragem, a presença dos homens que fediam à morte incita o herói vingativo a assassinar

\footnotetext{
${ }^{1}$ Lukács, Georg. Op. Cit. (p. 135)
} 
Claudemiro Marques, utilizando-se da surpreendente estratagema: espera que todos durmam e, sabendo por Jupira do sono encerrado a que Varjão entrega-se, banha com sangue de onça o corpo do delegado, o qual é devorado pelos seus próprios cães.

Com a morte de Antero Varjão, o povo, até então absolutamente marginalizado, aparece, ainda que de relance, como espectador e narrador desse fato que abala Corumbá. Primeiramente, o povo observa, atônito, a movimentação do Onceiro e de seus capangas indo para a caçada, e, momentos depois, constrói, a partir de diversas vozes, uma única história, coletiva, que perverte a realidade, mas que expressa a vontade da população, e dos revolucionários, em ver o dia em que a caça vinga-se do caçador:

"Uma onça imensa, malhada, segundo uns, negra e de olhos coruscantes feito uma noite estrelada, segundo outros, mas sempre pesada, descomunal, roel com os dentes, dizem uns, arrancou, segundo Euzébio, com as garras as grossas varas verdes da jaula em que a tinham prisioneira e foi esfrangalhar o Onceiro na rede em que se deitava, em que jazia, à espera da justiça divina na fúria das feras do Senhor” (p. 213)

À exceção do médico-legista, que descobre a artimanha de Quinho e depois a conta para os outros policiais, a versão de que Antero Varjão teria sido devorado por uma onça corre pela cidade inteira. Ainda que tenha agido apenas segundo seus instintos, comandados por Lucinda, e ignorado as orientações da Anistia Internacional e do Partido Comunista, Quinho passa a considerar-se o representante dos anseios da população, pois, como quer acreditar, teria ajudado a cidade a livrar-se da figura monstruosa do Onceiro. 
A exploração dos traços de personalidade de Claudemiro Marques (e também de Ari-Knut, como veremos a seguir ) abre uma perspectiva de leitura bastante diferenciada dos outros três romances analisados, tem voz autônoma: ele se presentifica através dos diálogos que mantém com o seu grupo, com Quinho e com Jupira, além dos longos monólogos interiores.

Em Sempreviva, Antônio Callado busca pesquisar a intimidade dos torturadores e, por isso, impede que as opiniões e sentimentos das vítimas contaminem o universo interior do delegado, ao contrário do que se verifica nos romances anteriores: em Quarup, é através da ótica dos personagens perseguidos pela repressão que conhecemos os policiais, por exemplo, Ibitinga, o qual, embora estabeleça alguns diálogos com os revolucionários, esses sempre ocorrem em função da sua incontrolável aversão às esquerdas brasileiras; em Bar Don Juan, os policiais inclusive Salvador, o estuprador de Laurinha, aparecem filtrados pelas emoções dos personagens; em Reflexos do Baile, os policiais até conquistam uma expressão autônoma através da troca de bilhetes, mas esse expediente não permite ao leitos entrever o que eles sentem e pensam, já que a linguagem utilizada é cifrada e referencial (a organização da repressão contra os esquerdistas).

A tentativa de compreender a lógica das emoções dos torturadores ganha concretude em Sempreviva. Nesse romance, o autor procura imaginar, fundamentalmente, para Claudemiro Marques, como seria o seu linguajar e quais seriam os seus conflitos interiores.

A exploração de Antero-Varjão/Claudemiro Marques e Ari-Knut/Juvenal Palhano reforça a necessidade posta pelo romance de romper com a visão 
monolítica do mundo, seja a dos revolucionários, seja a dos policiais, e de construir um olhar dialético sobre a realidade. Dessa maneira, Sempreviva aponta para a possibilidade de humanizar as relações sociais, a fim de promover a compreensão de todo o sentido dos conflitos nacionais e, não, de restringi-los a análises superficiais e estéreis.

São essas análises, segundo as histórias de Levindos, de Joãos, de Betos, que impedem a viabilização de um projeto revolucionário para o Brasil, exatamente porque os homens não conseguem construir uma perspectiva crítica e coerente sobre os acertos e os equívocos das suas ações sobre o mundo. Os homens, como Claudemiro Marques ou como Quinho, estão absolutamente cegos para pensar sobre si e sobre os outros, o que os leva a assumir uma postura contra a comunidade.

Utilizando um elenco reduzido de palavrões e um vocabulário, basicamente, sexual, do qual derivam neologismos como o verbo 'bucetar', os monólogos interiores de Claudemiro Marques surgem quase sempre de um ato de violência que cometeu ou que desejaria cometer.

Seus diálogos e monólogos traduzem a imagem comum de homem carente de sensibilidade e desvendam uma personalidade carente de raciocínio lógico, como bem observa o seu ex-companheiro de trabalho, Ari-Knut:

\footnotetext{
"Claudemiro era de matéria rude, rústica, homem claro de razão mas que ou entendia tudo na hora ou nunca mais queria falar no assunto, lerdo,incurioso, desdenhoso, sem as graças do desdém.” (p. 235)
}

O estupro e o assassinato que o delegado comete contra duas argentinas e contra os animais, entre eles, Jurupixuna, além das brutais caçadas que comanda, sensibilizam o leitor para compreender um universo absolutamente 
destituído de valore morais. O Onceiro age instintivamente, atropelando quaisquer códigos culturais. É um homem primitivo e, como Quinho, é incapaz de perceber as transformações da realidade e de readaptar-se a ela, perpetuando em si o sistema repressor.

O caráter autoritário e egocêntrico de Claudemiro Marques-Antero Varjão revela-se não apenas na as linguagem truculenta e na arbitrariedade com que realiza atos de violência, mas também na própria articulação dos seus pensamentos. Os devaneios do delegado-caçador navegam entre imagens absolutamente brutais, que se sobrepõem umas às outras sem compor uma linha coerente de raciocínio. A lógica de desenvolvimento dos pensamentos de delegado-caçador obedece tão somente à necessidade imperiosa de saciar seu potencial sádico:

"Antero calculou que podia se desligar do papo do cara, que tinha toda a pinta de durar até o saco estourar em frangalhos, porque gente era assim mesmo, só na porrada é que calava a boca, na porrada e na trepada, sendo que porrada, olhando bem as coisas, era melhor, servia sempre, liquidava logo a chatura de bicho vivo e gente viva, de maracajá que bole no mato e de puto metido a valente na hora do interrogatório enquanto que trepada ah tepada mesmo que não tem nada a ver com fode-fode nas Corinas e Violetas bucetas a gente só encontra uma vez, duas vezes e olhe lá, na puta vida inteira.” (p. 37)

As pessoas que se prestam a serem interlocutoras de Antero-Marques são obrigadas ou a contar com o seu desinteresse, ou a aceitar a imposição de uma fala personalista, pois ele não se dispõe a trocar qualquer experiência com o 'outro', assim com não se dispõe a observar a realidade e compreender os seus mecanismos. 
A radiografia da maneira como Claudemiro Marques pensa é muito semelhante à de Quinho. Ambos estão encarcerados em seus universos interiores e mantêm uma intersecção muito estreita com o real. Eles devaneiam em torno das suas obsessões e utilizam os que lhes cercam como meros instrumentos para a conquista de seus interesses pessoais, sejam eles de ordem prática ou não. É o que se lê quando Antero Varjão trata os homens como um meio de realizar os seus instintos primitivos e quando Quinho os entende como um pálido reflexo do seu passado ( Jupira/Lucinda; Hera/o filho morto; Juvenal Palhano/ o tioda sua infância).

$\mathrm{O}$ isolamento em que Claudemiro e Vasco encontram-se obstrui qualquer possibilidade deles transformarem a si mesmos ou à realidade, uma vez que suas ações e reações seguem, sempre, um mesmo padrão. Porém, a rigidez do comportamento dos personagens é problematizada quando emergem as questões profundas de suas vidas, que, se não chegam a desautorizar a relação que eles têm com o mundo, impedem que sintam esta relação como absolutamente satisfatória e verdadeira.

As questões que os atormentam são o sentimento de culpa que Quinho alimenta pela morte de Lucinda e o amor devoto de Claudemiro por Jupira. Essas rusgas na alma desestabilizam o universo interior dos personagens, levando-os a romper, temporariamente, com a postura habitual e a desenvolver pensamentos e ações inesperados.

Quando o sentimento de culpa de Quinho chega ao auge, como já apontamos, ele sai do estado contemplativo e parte para ação, chegando mesmo a cumprir a vingança num arroubo de coragem. $\mathrm{O}$ amor de Antero Varjão, que vem à tona poucas vezes, em cenas relâmpagos, fragiliza-o e faz 
com que assuma, instantaneamente, uma atitude passiva e reflexiva por causa do descaso da amada:

\begin{abstract}
"Claudemiro Marques estacionou a camioneta de modo a poder espreitar a casa dos seus cuidados, dos seus amores, mas com medo da espera, que podia ser longa, que podia, como tinha acontecido na buceta de onça preta da mata preta, rachar ele em dois, naquela pasmaceira e bobeira. Ultimamente Claudemiro cagava às vezes uma espera, uma paquera quando tinha que ficar quieto e só na espreita porque aí pensava e pensava na bobeira que tinha dado nele quando rastreava a jaguatirica-maracujá(...)"
\end{abstract}

Observando de longe a casa onde mora Jupira, Claudemiro espera, ao menos, vislumbrar a passagem pela janela do seu objeto de amor. Essa sua atitude contemplativa amedronta-o, porque o faz reviver o sopro de piedade que sentiu de uma jaguatirica mãe, um dia, no fundo da mata escura, quando cortara o seu rabo e ela, assustada, correra em direção aos filhotes para protege-los. Ao darse conta do pedaço do corpo do animal com que ficara na mão, Claudemiro Marques reconhece em si um seu duplo perigosamente humano e frágil, porque se deixa assaltar por uma recôndita tristeza causada pelo desespero da mãe ao querer proteger os seus filhos.

$\mathrm{O}$ encontro do personagem com um seu lado desconhecido previne Antero Varjão da caixa de surpresas que, no fundo nunca sondado de Claudemiro Marques, existe. A integridade do caráter do delegado-caçador é, como ele mesmo temia, rompida, e isso se denuncia a cada vez que ele deia vir à tona a doce lembrança de Jupira. Antero-Marques reage à cilada, recobrando sua gana de matar e violentar homens e animais: 
"Aí abri os olhos e ví que estava na frente da jaguatirica-maracajá e que ela tinha chegado na boca da toca dela, da caverna de morada dela e que os filhos dela estavam por ali e que aí é que aí eu vi e entendi que a porra do rabo dela, só me olhando, me olhando, me olhando, e eu acho que se avançasse em cima dos filhotes dela a puta da jaguatirica ia aprender a falar e ia começar uma lenga-lenga de mãe de puto em delegacia e xadrez pedindo pelos putos dos filhos mosqueados, de bigode de gato, e aí eu agradeci a lição de como é que tem gente que pena e se fode de pena dos outros - agradeci mesmo: joguei o pedaço de rabo da jaguatirica-maracajá no chão, de volta, e ela continuou olhando pra mim feito mãe de puto na delegacia enquanto os putinhos mosqueados de bigode de gato lambiam o cotoco de rabo de mãe, sai dessa" (p.137)

A lembrança da jaguatirica com seu rabo amputado e a paixão por Jupira são duas fendas na caracterização de Claudemiro Marques. Amor e piedade não combinam com o torturador e o caçador impiedosos, vistos, pela população e pelos revolucionários, como a encarnação do mal, como uma doença brasileiríssima, causada pelos movimentos mesmos da pátria, que deve, porém, ser extirpada.

O medo de Claudemiro Marques sente de reconhecer seus conflitos emocionais faz com que ele oculte de si mesmo seus outros "eus" por não conseguir lidar com sentimentos que o obrigariam a identificar-se com a humanidade e que, consequentemente, iriam torná-lo suscetível a ela:

"Medo é modo de dizer, medo os culhões, que não tinha medo de porra nenhuma, mas preferia não levar a paquera e o campaneamento ao ponto de virar doi caras, um vigiando o outro sem ser visto do outro, Claudemiro investigando Antero, Marques averi- 
guando Varjão, ninguém vendo ninguém, porra qual é? Medo não tinha de puto nenhum, nem dele mesmo, e de coisa nenhuma, mas é que quando tinha caído, no meio do mato, naquela ausência, tinha virado mesmo dois homens, dois caralhos e quatro culhões, besteirão perdido dele mesmo e do mundo, se esquecendo que puto que era, onde é que estava e porras assim que não queria mais que acontecessem, porra.’(p.134)

É como se por trás da clandestinidade do delegado, houvesse um outro homem também de vida clandestina. $\mathrm{O}$ amor que o Onceiro sente é tão dissimulado quanto o é a sua verdadeira identidade. Esse sentimento é sufocado, mas permanece latente em seu comportamento, o que se revela no respeito dispensado a Jupira e ao seu pai, o velho Iriarte, único homem a arrefecer os seus desejos assassínios:

"Via dali a casa, ou pelo menos a loja importada que ocupava toda a frente da casa, e até no meio da loja, debruçado na meas dos livros de caixa, cachimbão na boca, o pai, que não dava a Claudemiro vontade de matar por causa da vara que ele tinha e que Claudemiro quase que enxergava também do volante, dormida e quente por trás da braguilha e cuja cabeça tinha esguichado pra dentro duma cona guaicuru forrada de goiaba uma nuvem de porra que tinha virado ela, olha lá, a própria.’( p132)

Embora Claudemiro subordine-se aos desejos de Jupira, ao ponto de atender a suas ordens para que não aparecesse mais na casa dos Iriartes sem ser convidado, ele alimenta seu ódio por Quinho, Herinha e o seu macaco, Jurupixuma. Ao encontrar, um dia, os três juntos, na rua, Antero Varjão jura 
para si mesmo destruir a alegria irritante deles, motivado pelo ciúme mortífero da mãe da menina

A imagem de Claudemiro Marques enquanto homem sem valores morais e éticos coloca em tensão a possibilidade de ele ser capaz de amar ou de apiedarse de alguém, uma vez que as torturas feitas contra o macaco, direta ou indiretamente, atingem Jupira e esmagam a lembrança da Jaguatirica mãe. Os maus tratos realizados contra o Pixuna é a única forma possível encontrada pela personalidade rude de Antero Varjão de sufocar o amor e a obediência devotados a Jupira e o tanto de piedade que a figura 'babaquinha' de Herinha inspiram nele.

A tentativa de a narrativa pesquisar o universo interior de um torturador avança no que os outros policiais têm de caricatural. As contradições presentes em Claudemiro Marques, ainda que muitos sutis, despertam o questionamento sobre o estereótipo dos homens da repressão e, consequentemente, da visão que se tem sobre as décadas do terror no Brasil.

A sondagem do imaginário desses homens expressa a necessidade de compreender as engrenagens da máquina ditatorial e de vasculhar o que é que gerou um estado tão profundamente violento como o foi o brasileiro, para, então, criar a possibilidade de imaginar um novo projeto para este país de índole tão desumana quanto violenta.

Buscar as raízes da personalidade de Claudemiro Marques é buscar as raízes do autoritarismo no Brasil e desmascarar, como já apontava Reflexos do Baile, a farsa a que o país entregou-se ao banhar-se com as cores do carnaval, do futebol, das muitas raças do povo brasileiro maravilhosamente cordato. O que surpreende nesta incursão que Sempreviva faz ao coração do Brasil é que as raízes da repressão estão no extremo oposto da barbárie, estão mesmo nos 
germes do amor e da piedade, segundo, o que nos ensina o torturador Claudemiro Marques e, conforme veremos a seguir, o médico-legista Ari-Knut.

Quinho ao descobrir a verdadeira máscara de Ari-Knut, lamenta a perda do estimado amigo Juvenal Palhano. A imagem do médico-legista morto pela picada venenosa de Joselina provoca em Vasco uma profunda satisfação por ver sua vingança cumprida e, ao mesmo tempo, uma longínqua saudade daquilo que Juvenal Palhano representava: o naturalista, amante das óperas e sinfonias, bondoso e amigo, sempre disposto a ouvir o desabafo daqueles que o solicitavam:

“Ite, ide, pensou Quinho que - reverente mas sobretudo alegre diante daquele inimigo que lhe era, antes do combate, ofertado numa salva, diante de tão deleitoso cadáver - protelou, adiou a própria curiosidade de saber como morrera Palhano-Knut, já que o fato insigne daquele passatempo era sua convivência, seu a propósito, os sinos dobrando a finados com tamanha pontualidade e justeza harmônica, que Quinho evocou, quase com ligeira afeição, o amor que nutria pela música uma parte, pelo menos, do finado, a parte Juvenal Palhano.” ( p. 289 )

A caracterização de Juvenal Palhano é cuidadosamente trabalhada ao longo do romance, o que torna muito sutil, para os que o circundam e para o próprio leitor, a ambiguidade dos símbolos criados em torno desse personagem, os quais, apenas numa segunda leitura, podem evidenciar a existência do seu duplo Ari-Knut.

O cultivador de plantas carnívoras atrai Quinho para sua rede mortífera assim como atraíra Lucinda, pois Palhano-Knut, conforme conta para Jupira ao final 
da narrativa, sabia desde os seus primeiros dias em Corumbá de todas as redes tramadas pelo Partido Comunista e pela Anistia Internacional. O naturalista assume ter tido acesso a todas as correspondências enviadas por Liana a Quinho, inclusive a última, em que ela revela ao ex-exilado a verdadeira máscara do médico-legista, Ari-Knut.

Com sua imagem carismática, Juvenal Palhano seduz todos aqueles que o cercam, inclusive o próprio leitor, porque, em meio a tantas vidas fraturadas pela violência do Estado ditatorial, é o único personagem que, aparentemente, pratica ações solidárias e mantém relações sem quaisquer interesses pessoais, senão pelo prazer mesmo de expor sua cultura universal.

Além do seu jeito dócil, a própria composição física de Juvenal Palhano contribui para a confiança que ele inspira na família dos Iriartes e em Quinho:

"Pequeno, sólido e calvo, em mangas de camisa e, feito um simples dono de casa que ama seu jardim, ostentando manchas de terra nas mãos, nos joelhos das calças, Juvenal Palhano usava pincenê, como Zola, Machado e Olavo Bilac. Caiu-lhe, aliás, o pincenê do nariz, e ficou dançando contra o seu peito, pendente de um cadarço preto, à medida que Juvenal Palhano corria de braços abertos até se ajoelhar, na varanda, aos pés da menina e da chapeleira, antes de se postar, sorridente, diante do estranho que o visitava pela primeira vez" ( p.77 )

Envolto em toda essa aura acolhedora, que se estende à sua aconchegante chácara, onde trabalham as duas simpáticas empregadas, Malvina e Cravina, Juvenal Palhano cega os mais experientes comunistas, que sequer desconfiavam da verdadeira identidade do amável cultivador de droseráceas. 
Quinho se sente atraído pela figura de Juvenal Palhano e pelo espaço bucólico em que ele mora. Tal composição dá ao protagonista o conforto e a confiança na vida que sentia quando era criança. A ambientação forjada pelo médicolegista provoca em Quinho a ilusão de rever no naturalista a doce personalidade que fora um dos seus mais queridos tios, o Tio Lulu, e o induz a revisitar o lar e a infância idealizados. A pureza e a tranquilidade encontradas na chácara de Juvenal Palhano ganham intensidade no contexto geral do romance, já que a terra natal transformara-se, para o exilado, em um verdadeiro inferno:

“Aquele era o sol que brilhava no quintal da casa do seu tio Lulu, e Quinho, pela primeira vez desde o regresso, sentiu uma mansa vontade de chorar choros de outrora, não como o que chorava, por exemplo, ao cortar, com a lâmina menor do canivete Solingen, raspando a forquilha de goiabeira, a polpa da sua mão esquerda, e sim choros indefiníveis, meio prazenteiros,de cansaço ao cabo de um dia de colégio pela manhã e banho de mar à tarde, ou, simplesmente, de pura irritação, à noite, por não querer deixar a sala de jantar para ir dormir. Pela greta das pestanas úmidas, Quinho percebeu que, do tubo de tinta, saíra também, destacando-se das árvores feito um duende, seu finado Tio Lulu, pobre, cachaceiro que só discutia com calor o preço do alpiste e dos canários da terra.” (p. 76)

Homem e natureza irmanam-se em Juvenal Palhano, que se torna uma fonte de energia para Jupira e para Quinho. Em momentos de desespero, o protagonista visita-o, a fim de reconquistar a calma necessária para suportar o 
terror de conviver com os assassinos de Lucinda e recobrar a confiança em si e nos seus planos de vingança.

A cuidadosa construção desse terno personagem e da atmosfera que o envolve acentua a profunda ironia que vai se configurar ao final da narrativa com a revelação da sua verdadeira identidade. Ciente dos motivos da volta do exilio de Quinho e dos reais interesses dos Iriartes, o médico-legista é o único a dominar o jogo velado entre comunistas e policiais, comprazendo-se com os enganos e acertos de cada parte e deleitando-se com as desesperadas ações do protagonista para encontrar os torturadores de sua ex-companheira.

$\mathrm{Na}$ terceira e última parte de Sempreviva, a narrativa abandona a ótica dos Iriartes, do delegado-caçador e a de Quinho, e converge para a do naturalista. A partir desse momento, chegam ao leitor os diálogos francos que o médicolegista tem com Jupira e com policial Trancoso, a quem informa a verdadeira causa da morte de Claudemiro e ordena que mande Dianuel, outro dos policiais-caçadores, matar Quinho

Ari-Knut revela o quanto desprezava os outros policiais, que para Pantanal também tinham ido junto com Miro, como o ex-delegado era chamado pelos amigos. Vendo-os como 'bolhas' e de inteligência limitadíssima, o médicolegista afeiçoara-se e desfrutara de imenso prazer de viver sob a máscara de Juvenal Palhano, já que pôde desligar-se dos torturadores e dedicar-se ao estudo e o cultivo de plantas exóticas:

“A primeira confidência - guarde-a antes que um muro de pedra, alto, suba entre nós - é que nunca me senti tão venturoso, em tempo, breve demais, em que vivi aqui, eu, Juvenal Palhano. E mais venturoso ainda me senti quando nosso Quinho viu em mim a transmigração e o avatar de Lulu, o tio, tão simples - quase, entre nós, simplório mas encantador, arquetio, poderíamos talvez dizer sem pedantismo, 
Nas cenas finais, Knut passa a Palhano, e este àquele, sob as vistas de Jupira, de Trancoso e do próprio leitor, com uma versatilidade que chega a impressionar pelo competente desempenho que ele apresenta ter em papéis essencialmente divergentes. O médico-legista sofre ao abandonar sua máscara cultivada com tanto esmero, seu 'outro' absolutamente contrário à sua vocação sádica, do qual aprendeu mesmo a gostar.

Knut é um paradoxo, assim como as demais personagens de Sempreviva, o que confirma para o leitor, mais uma vez, a necessidade urgente de desconfiar do senso comum de realidade e de desautomatizar as antigas práticas judiciosas segundo as ordens maniqueístas: Deus e o Demônio, Capitalismo e Comunismo, Opressor e Oprimido.

Num turbilhão de imagens, Sempreviva descreve a vitória final de Lucinda, quando Dianuel, com uma coronhada de revólver, mata Quinho, "Isto é, impunha-lhe, num cone de escuro pano, a escuridão do cinema, onde Quinho ainda teve tempo de ver o copo que afinal se estilhaçava no chão." Livre de ser, ele mesmo, Quinho, sua própria prisão, a consumação da vingança põe fim ao sentido da sua vida, restando-lhe apenas a gratidão ao capanga do Onceiro de obriga-lo a ir fazer morada, definitivamente, junto aos mortos: "E desta vez ele guardou para sempre, na sua, sem soltá-la, a mãe de Lucinda, e guardou ela própria, toda ela, Lucinda perene, perpétua, imortal, sempreviva."

A reunião, neste romance, de símbolos nacionais como o canto do sabiá, as palmeiras e a paisagem exuberante de Corumbá - reforçados pela 
intertextualidade mantida entre Sempreviva e poemas de Gonçalves Dias ('Canção do Exílio’), Casimiro de Abreu ('Os Meus Oito Anos'), Olavo Bilac ('Via Láctea') e Álvares de Azevedo ('Noites na Taverna') - fixa a visão idílica da pátria, através da qual tudo se mantém sob o signo da inocência e da benevolência.

Grande parte dessas imagens da terra natal está associada, direta ou indiretamente, à imagem de Juvenal Palhano, em quem Quinho projeta a sua infância perdida e o arquetio Lulu. Porém, com a revelação da verdadeira figura do naturalista, o quadro paradisíaco da "minha terra tem palmeiras/ onde canta o sabiá" sofre um profundo desgaste pela ironia que nasce da identificação, tecida ao longo da narrativa, entre o médico-legista e a mãe natureza.

Os símbolos nacionais tornam-se, também eles, duplos paradoxais. O sabiá Verdurino carrega consigo tanto a lembrança de um tempo paradisíaco - pois transporta Quinho para as belas paragens da sua infância idealizada - quanto o embuste e a morte - pois, pelas mãos de Hera, engana Juvenal-Knut e o faz partir para a definitiva viagem ao mundo de Lucinda.

A idealização do interior do Brasil perde seus contornos, assim como Juvenal Palhano-Ari-Knut perdera os seus na dança das máscaras. O leitor vêse na obrigação de compreender os símbolos pelo seu próprio avesso, já que os limites que definem a versão verdadeira dos fatos são tão inapreensíveis como os limites das falsas versões. Ao final, o romance adverte para o fato de que quanto mais valorizada for a paisagem natural, mais relativizada ela deverá ser.

O cenário exuberante e pictórico dos trópicos sugerido em várias páginas é sugado pela atmosfera letárgica e pelo tempo infernal do romance, que ficaram aprisionados nos porões da ditadura, onde se debatiam torturados e torturadores: 
“Apesar de já ser noite alta quando saiu da casa de Jupira, Quinho sentiu, na rua, o calor que fazia, malévolo, exagerado para ser aceito assim sem mais nem menos, intencional como se todas as alpacas da Bolívia tivessem sido, por mão enormes, esfoladas, a lã transformada no gigantesco abafador de bule de chá que baixara do Antiplano para pousar, com surdo baque imortal aconchego sobre Corumbá. Alguma coisa devia estar para acontecer se uma rua noturna arquejava assim, prostrada pelo calor debaixo de palmeiras carandá tão imóveis que, vistas de baixo, pareciam ter as palmas marteladas, damasquinadas à moda toledana no céu e não soltas e livres no espaço.” (p.57)

A narrativa compõe um jogo de espelhos. Assim como os símbolos são paradoxais ( o sabiá, as plantas, a floresta, as onças ), os personagens também o são, pois possuem um seu duplo, dois modos de ser, suas visões de mundo conflituosas. Quinho, ao voltar para o Brasil, para o lugar que deveria representar o centro da sua vida, adivinha-se perdido e amedrontado, sabendo ser um homem dividido entre duas necessidades, vingar a companheira assassinada e soterrar seu passado. Lucinda expressa a dor e a indignação dos revolucionários, mas age tão somente segundo a sua gana de vingança. Jupira é mártir e portadora da má sorte àqueles que ama, é a heroína das causas sociais e a sua maior traidora. Os sentidos sádicos de Claudemiro são aguçados pelo amor e pela piedade que homens e animais despertam nele. O médico-legista 
identifica-se com a bondade e o carisma do naturalista Juvenal Palhano. E Herinha combina à inocência da infância a malícia do mundo adulto.

O que subjaz à impossibilidade de unir os duplos num todo complementar é o que, em última análise, teria motivado as práticas dos governos ditatoriais, a negação radical de comportar a diversidade, haja vista que, conviver com o diferente, implica em não dominá-lo, em tornar o poder suscetível a lógicas mais humanitárias.

Como os personagens não admitem os seus conflitos como parte daquilo que realmente são, eles não conseguem superá-los, como Nando e Laurinha conseguiram, e não conseguem entender e aceitar nem a si mesmo, nem o outro em sua plenitude e nem a tortuosa história do Brasil. Outrossim, à exceção de Jupira, eles se deixam conduzir por propostas que não contemplam, sob nenhuma hipótese, a multiplicidade, a diversidade de vidas e maneiras de pensar e de viver, que não contemplam, mesmo com todos os embates contra o real, as máscaras multifacetadas do Brasil.

Portanto, o autoritarismo nasce, como nos ensina Claudemiro Marques, da insegurança e do temor do desconhecido, e a violência, da impossibilidade de o homem compreender a si e aos outros como parte de uma construção fragmentada (Lukács) e monstruosa. O homem reage de maneira vil e inconsequente contra os que, de alguma maneira, representam as faces do Brasil. É assim que Antero Varjão-Claudemiro Marques, Lucinda, Quinho, Juvenal Palhano-Ari-Knuto, e a própria Herinha reagem ao inimigo, com violência e autoritarismo.

Jupira é, na galeria de personagens de Sempreviva, a única e não perpetuar o autoritarismo e a não sobrepor seus interesses pessoais aos da coletividade. Se Lucinda representa a corrupção do ideal romântico feminino, Jupira impede que 
este se desmanche totalmente, porque consegue compreender a frenética transição entre o Bem e o Mal, entre a vida e a morte e entre a coletividade e a individualidade.

É Jupira quem propõe, ainda timidamente, uma saída para o caos brasileiro, pois, com paciência e sabedoria, busca pôr em prática a justiça contra os que violentaram o Brasil sem que, porém, isso signifique uma vingança pessoal. Essa vingança, perseguida por Lucinda e por Quinho, ao invés de representar um aprendizado (com o é a justiça tardia), representa o desabafo dos oprimidos e a perpetuação do autoritarismo e da violência, já que não promove qualquer mudança especial na vida do país.

Porém, como tudo em Sempreviva, até essa atitude de Jupira tem seu duplo, pois a sua postura é lida e reproduzida às avessas pela filha. Herinha corrompe e esteriliza as intenções da mãe de promover justiça, já que ela mesma responde ao mundo com a violência que lhe fora ensinada pelos adultos, portanto, silenciosa e maliciosa, a morte de Ari-Knut.

A criança ironiza todos os imaginários utópicos que lhe precederam, pois nenhum foi capaz de ensinar-lhe outros caminhos que não o da morte e o da dissimulação. É esse o caminho das novas gerações e é esse o caminho do Brasil.

A história de Sempreviva faz um recorte vertical do período ditatorial, pois evidencia o mundo pessoal das personagens em detrimento da realidade nacional. Isso não quer dizer que o romance possa ser lido como um romance psicológico. Ao contrário, o que Antônio Callado faz é mostrar como os acontecimentos das décadas de 60 e 70 fraturaram, de forma irreversível, o 
universo interior dos homens, uma vez que o terror e a truculência das autoridades destruíram a possibilidade de se projetar um mundo mais igualitário.

O olhar do leitor é conduzido dos mecanismos sociais para as subjetividades dos personagens, da comunidade para o indivíduo, da tentativa de compreender o papel dos homens na história nacional para a de compreender a lógica da trama das emoções e dos pensamentos desses homens. A narrativa acompanha, enfim, a individualização do homem numa sociedade autoritária, o que causa, irremediavelmente, a perda das utopias sociais.

Desde Bar Don Juan acompanhávamos esse movimento, mas naquele romance ainda existia a proliferação dos pequenos e medíocres sonhos pessoais, que buscavam realizar-se, de alguma forma, dentro de um espaço coletivo. Em Sempreviva, as fissuras abertas no universo de cada personagem tornam-nos cegos para o 'outro', os homens circulam pelo interior do Brasil sem conseguirem conquistar uma comunicação efetiva entre sí.

As semelhanças entre $\mathrm{o}$ mundo interior dos torturadores $\mathrm{e} o$ dos revolucionários são, como vimos, muito mais acentuadas do que suas diferenças. Paradoxais e descentrados, torturadores e combatentes buscam apenas compensar, de alguma forma, suas frustrações pessoais, o que os impede de viver em comunidade.

Até mesmo a romantização da figura feminina desenvolvida nos quatro romances de Callado sofre graves arranhões em Sempreviva. Lucinda, a grande vitoriosa do duelo contra Claudemiro Marques e Ari-Knut, só trabalha, como vimos, pela realização dos seus desejos, ignorando a possibilidade de fazer com que seu principal instrumento de ação no mundo dos vivos, Quinho, 
desse um alcance social maior para sua estada em Corumbá, seguindo, ao menos, os planos da Anistia Internacional.

Sempreviva redimensiona as teorias lukacsiana sobre a fragmentação do herói no romance moderno, uma vez que o insere em um contexto fortemente marcado pela violência institucionalizada. O 'romantismo de desilusão' que a trajetória do herói define nesse romance não caminha para o 'romance da aprendizagem', como vimos ocorrer em Quarup e em Bar Don Juan. Também aqui a narrativa não chega a negar a estética realista proposta por Luckács, como em Reflexos do Baile. Sempreviva mantém-se entre as duas propostas, pois, se o autor crê serem insuficientes os expedientes oferecidos pelo realismo para promover a construção de um romance sobre as décadas de 60 e 70, também não quer romper com esses expedientes, uma vez que isso significa tornar a comunicação com o público leitor ruidosa e ineficiente.

Buscando um romance ao mesmo tempo realista e experimental, Antônio Callado flagra as incertezas da própria ficção em um país que desrespeitou todos os direitos dos homens. A perda das ilusões esvazia o significado humanitário da vida em sociedade e subordina esta vida, individualista e solitária, a uma história comandada por alguns poucos homens, os quais, como podemos deduzir a partir de Claudemiro Marques, encontram-se igualmente perdidos e amedrontados.

Toda a luta de uma geração para a transformação das condições de vida no Brasil, resgatada em Quarup, é corrompida pelo esvaziamento do sentido dessa luta. Não há na tetralogia aqui estudada, desde Bar Don Juan, a projeção de um outro Brasil que justifique a luta revolucionária, ao contrário, os romances dão um quadro bastante trágico das esquerdas nacionais, que 
marginalizam, ou que não conseguem incluir nos seus planos, os interesses verdadeiros da nação.

Quarup, Bar Don Juan, Reflexos do Baile e Sempreviva detacam-se dos tantos outros romances que têm como cenário o período ditatorial, pois vêm não apenas revelar o lado oculto da história do poder opressos no Brasil, mas dos próprios movimentos revolucionários. Os romances colocam em dúvida se, de fato, em algum momento da História Nacional, houve a possibilidade de se construir uma utopia coletiva interessada em acabar com a miséria, moral e física, da população ou se essa utopia veio apenas preencher o imenso vazio do homem moderno terrivelmente violentado pelos sucessivos e insubstituíveis governos opressores tão fortemente presentes na História do Brasil. 
4. Conclusão

"Olhar para o nosso passado - nosso, das mulheres que foram até o fim nas experiências questionamentos, lutas que estavam em pauta naqueles anos - significa ver cicatrizes $e$ uma bem pesada bagagem: o sentimento de que sobrevivemos a nós mesmas, às nossas mas caras crenças, ao companheirismo e afeto da relação entre os militantes, aos amigos mortos ou destruídos de outras formas.

Olhar para o passado revela o que somos hoje: não desistimos da utopia. Mesmo que não tenhamos mais o mapa do caminho, resistimos à destruição da generosidade e da esperança. Mesmo sem nenhuma grande certeza monolítica, mas com pequenas certezas e muitas dúvidas, não renunciamos às raízes do gesto. Cabe, com exatidão relativa aos nossos dias atuais, a estrofe de Drummond: 'Mas as coisas findas, mito mais que lindas, estas ficarão'. "

(Trecho do livro inacabado de Vera Sílvia, ex-combatente política, transcrito no livro Mulheres que foram à luta armada, de Luiz Maklouf Carvalho.) 
A falência do imaginário utópico das esquerdas determina, como vimos, a construção da trajetória que os 'heróis' desenvolvem ao longo dos quatro romances, a qual foi analisada segundo a tipologia lukacsiana descrina na

\section{Teoria do romance.}

Em Quarup, a projeção do imaginário utópico das esquerdas leva Nando a aderir à luta armada, depois de um profundo mergulho em si mesmo e na história do Brasil. O conhecimento da sua intimidade e o da realidade, que se dão por intermédio das mulheres que amou, permitiram a Nando romper com a 'cegueira' a que estava condenado e a recuperar o sentido da vida.

Tal trajetória do herói define, pois, a construção do 'romance da aprendizagem'.

Em Bar Dom Juan, as violentas torturas e assassinatos cometidos pelo estado impedem João de construir canais de comunicação que viabilizem a sua interação verdadeira com o mundo e barram qualquer ação que busque promover transformações pessoais ou coletivas. Nesse contexto de absoluta opressão, João entrega-se a uma conduta hiper-ativa que o priva de desenvolver uma reflexão coerente a respeito das suas atitudes frente à caótica e terrível realidade brasileira.

A morte trágica do protagonista termina por construir o 'idealismo abstrato' na primeira parte do livro. Paradoxalmente, esse fato é o pressuposto para a fundação de um outro tipo de romance dentro do mesmo Bar Dom Juan, o 'romance da aprendizagem', que abrange a segunda parte da narrativa, cuja protagonista, Laurinha, liberta-se da dor e enfrenta ao longo e tortuoso caminho da aprendizagem 
Reflexos do Baile abole as categorias narrativas tradicionais e nega a estética realista, o que denuncia a impossibilidade de se compreender a brutal condição a que o país e os homens foram submetidos e a de traduzir esta situação através de uma linguagem objetiva, clara e lógica.

Depois dos terríveis desgastes da esquerda com o decreto do Ato Institucional de número 5 , as utopias naufragam no obscuro processo histórico brasileiro e as últimas ações armadas flagram os terríveis equívocos da luta contra a ditadura. O caos literário procura plasmar o estilhaçamento das esquerdas e do próprio ser humano, eliminando qualquer possibilidade de ver ressurgir heróis e projetos que proporcionassem a construção de uma saída para a crise em que o Brasil se afundara.

Sempreviva recupera as categorias narrativas, porém, para negar muitas das suas características. $O$ romance que fecha a tetralogia representa, por isso, ao mesmo tempo, um retorno à estética realista e a ironização desta mesma. A história do Brasil resgata por esse romance passa a ser lida como uma farsa tanto do ponto-de-vista dos policiais, quanto do dos comunistas.

Se Quinho foi esterilizado pelo poder opressor e o estado não consegue conviver com a imagem terrível que forjara de si, há que se pensar um novo projeto para o país. Todavida, o problema que se coloca é que tanto os representantes do povo como os das elites não conseguem gestar o futuro por estarem perdidos por entre os fragmentos das suas individualidades.

A trajetória de Quinho define o 'romantismo da desilusão' e traz a falência definitiva dos imaginários utópicos. Contudo, quando se pensa que o fim é chegado, definitivo, irreversível, ele se torna motivo de ironia na voz do narrador, e, mais uma vez, a história parece querer reviver. 
"Agora, repicavam os sinos de grande ite, ide, vade, cada um que se defenda, que arrume, lá fora, as alegrias que puder, e evite, como Deus for servido, os aborrecimentos. Se mandem, por obséquio, que está na hora de varrer a igreja, vão embora, não esqueçam nada nos bancos, nos genuflexórios, e raspem-se daqui, sumam que a missa acabou, o altar se apagou, temos todos muito que fazer, a começar pelo padre e o sacristão, bom proveito para quem comungou sangue de anho ou novilho, agora chega de tragédia, é hora do cada um por si e Deus por todos e quem quiser que conte outra que aqui o livro acabou, xô, gente, ide que a missa já era, foi e acabou." (Sempreviva, p. 286)

A ironização da pátria dos homens e da própria narrativa rompe com o olhar judicioso que os outros romances construíram e propõe o desafio de que a história brasileira seja compreendida para além das perspectivas limítrofes - porque maniqueístas - traçadas pela esquerda e pela direita nacionais.

A crise das utopias desce pelas ladeiras da intolerância, mas Antônio Callado não permite que isso se faça em silêncio. Costurando, como a cobra Joselina, os retalhos do tecido, Callado remenda os fragmentos para "gente grande compreender figura completa de coisa que só aparece aos pedaços, em tira de pano" e propõe um caminho para que se torne possível imaginar o porvir: a construção de uma memória histórica que não exclua nenhum grito, nenhum sussurro, nenhuma dor, nenhum prazer.

A memória histórica que Callado persegue busca juntar à história oficial o silêncio dos oprimidos. Contemplando todas as vozes nacionais torna-se

\footnotetext{
${ }^{1}$ Sempreviva. p. 264
} 
possível mergulhar, verdadeiramente, no Brasil e na alma dos brasileiros, a fim de desvendar o que de fato eles escondem por de trás das máscaras forjadas ao longo dos sucessivos governos opressores.

Recuperar os estilhaços das subjetividades e da realidade em uma memória histórica que contemple as diversidades nacionais é aprender com os acertos e com os equívocos dos rumos da história brasileira. Callado quer agarrar e entender o passado, para, então, imaginar um projeto para a nação, o qual só terá possibilidade de ser conquistado se cada cidadão encontrar nele a sua realização pessoal.

A figura feminina centraliza, nos romances estudados, as qualidades para romper o engessamento do ideário utópico, a fim de reconstruí-lo sempre que preciso. Isso ocorre exatamente porque o ser feminino, visto a partir dos símbolos que a cultura humana criou para diferenciá-lo do ser masculino, coloca em prática o amor livre, gratuito, desinteressado e por conter a capacidade de compreender as diferenças e reuni-las em um todo complementar.

A busca do feminino, ao contrário do masculino, representa a aliança dos desejos íntimos aos coletivos, concretizada na busca simultânea da satisfação sexual e da solidariedade ao próximo, da constituição de uma família e da consolidação da vida em comunidade, do encontro consigo mesmo através do encontro com o outro, da união do plano material ao plano espiritual. O caminho desta busca está na capacidade de reconhecer as faces terríveis do Brasil e dos homens, para que, ao invés de os brasileiros ingressarem em mal fadadas aventuras, aprendam com os destinos individuais e coletivos. 
Homem das letras, jornalísticas e literárias, Callado procura novos rumos para a trágica história nacional e, para tanto, quer elaborar o luto ${ }^{1}$ pela utopia comunista que, no Brasil, muito precocemente fora abortada pela truculência das elites políticas e econômicas. $\mathrm{O}$ autor reconhece a debilidade do imaginário das esquerdas diante do violento poder opressor e, como o padre de Sempreviva, prepara-se para imaginar outras emendas para a história, outros devir.

Callado leva seus leitores ao interior do Brasil e dos homens e os conduz ao doloroso reconhecimento de que as esquerdas fracassaram e de que as tantas vidas que bancaram a luta contra o autoritarismo não conquistaram a revolução sonhada. Porém, ele vai além da melancolia que assolou os revolucionários e intelectuais de esquerda e que os jogou, novamente, à margem do processo histórico, pois propõe uma lúcida reflexão sobre as causas e as consequências da falência das utopias e projeta uma nova perspectiva, pautada no imaginário feminino, que não sabe separar a revolução social da revolução íntima, subjetiva.

O autor de Sempreviva supera os limites do realismo histórico, sem, contudo, abandoná-lo, da mesma maneira que supera o estilhaçamento do imaginário utópico das esquerdas, sem deixar de ser, em nenhum momento, um atento crítico à condução do processo histórico brasileiro, investigando, através do seu incansável engajamento político, social e intelectual, uma nova estética para a literatura e para a vida.

\footnotetext{
${ }^{1}$ Stein, Ernildo. "Penso que podemos vincular a nossa reflexão sobre o problema da decadência do socialismo e das esquerdas ao problema do que eu chamo da utopia e da melancolia. Em outra análise, vimos que em toda a postura depressiva, melancólica frente à realidade do mundo, à realidade social, quando ela tem uma determinada espessura e uma determinada elaboração, aparece a ideia da utopia. Na ideia da utopia visa-se uma crítica à transformação do estabelecido.”. Op. Cit. (p.p. 46)
} 


\section{BIBLIOGRAFIA}

\section{Obras de Antônio Callado}

\subsection{Ficção}

CALlADO, Antônio. Assunção de Salviano. 2.ed. Rio de Janeiro, Civilização Brasileira, 1960. (Vera Cruz: Literatura Brasileira, 21).

Bar Don Juan. Rio de Janeiro, Civilização Brasileira, 1971. (Vera Cruz: Literatura Brasileira, 151).

A Expedição Montaigne. Rio de Janeiro, Nova Fronteira, 1982

Missa do galo: variações sobre o mesmo tema.10 ed., São Paulo, Summus, 1977. p.65-76.

A Madona de Cedro. 2. Ed. Rio de Janeiro, Nova Fronteira, 1981.

Capítulo VIII. In: CONDÉ, João, coord. O mistério dos MMM. Rio de Janeiro, Tecnoprint, sd.

Quarup. Rio de Janeiro, Civilização Brasileira, 1967. (Vera Cruz: Literatura Brasileira, 120).

- Reflexos do Baile. Rio de Janeiro, Paz e Terra, 1976. (Literatura e teoria Literária, 10).

Sempreviva. Rio de Janeiro, Nova Fronteira, 1981. - Concerto Carioca. Rio de Janeiro, Nova Fronteira,

- Memórias de Aldenham House. Rio de Janeiro, Nova Fronteira, 1989

\subsection{Teatro}

CALlADO, Antônio. A cidade assassina. Rio de Janeiro, José Olímpio, 1954

Forró no Engenho Cananéia. Rio de Janeiro, Civilização Brasileira, 1964. 
Pedro Mico. O tesouro de Chica da Silva. Uma rede para Iemanjá. Rio de Janeiro, Tecnoprint, 1970.

A revolta da cachaça. Teatro negro. Rio de Janeiro, Nova Fronteira, 1983.

O fígado de Prometeu. Rio de Janeiro, Nova Fronteira, 1951.

Frankel. Rio de Janeiro, Nova Fronteira, 1955

O colar de Coral. Rio de Janeiro, Nova Fronteira, 1957

\subsection{Ensaio}

CALlADO, Antônio. "O artista deve ter liberdade de criar?” Visão, São Paulo, p.52-62, 16 fev. 1968.

. Entre Deus e a vasilha. São Paulo, Nova Fronteira, 1995.

. "Destruição da natureza: ações e omissões". Argumento,.

Rio de Janeiro, 1(1):104-6, out. 1973.

. "Literatura e realidade". In: RIBEIRO, Darcy e outros.

Ensaios de “Opinião".. Rio de Janeiro, Inúbia, 1978 p.38-42.

(Ensaios de "Opinião", 9)

Retrato de Portinari. Rio de Janeiro, Paz e Terra, 1979.

"As três viagens de escritores latino-americanos". In:

GERBER, Raquel e outros. Ensaios de "Opinião". Rio de Janeiro, Inúbia, 1978 p.94-9. (Ensaios de "Opinião”, 6)

\subsection{Prefácio}

CALLADO, Antônio. Introdução. In: FISCHER, Ernst. A necessidade da arte: uma interpretação marxista. Tradução de Leandro Konder. 2. ed. Rio de Janeiro, Zahar, 1967. p.7-10.

Prefácio. In: FERREIRA, Bibi e outros. Paulo Pontes: a arte da resistência. São Paulo, Versus, 1977. p.6-8.

Prefácio. In: GOMES, Dias \& GULLAR, Ferreira. Dr. Getúlio, sua vida e sua glória. Rio de janeiro, Civilização Brasileira, 1968. p.XIII-XVIII. 
CALLADO, Antônio. Esqueleto na Lagoa Verde. A seca fria. Brasília, MEC, 1961.

Os industriais da seca e os "galileus" de Pernambuco. Rio de Janeiro, Civilização Brasileira, 1960.

. Passaporte sem carimbo. Rio de Janeiro, Avenir, 1978

Tempo de Arraes: a revolução sem violência. 2 ed. Rio de Janeiro, Paz e Terra, 1979. (O mundo Hoje, 34).

Vietnã do Norte. Esqueleto na Lagoa Verde. 2 ed. Rio de Janeiro, Paz e Terra, 1977. (O mundo Hoje, 25)

1997.

Crônicas de fim de milênio. Rio de Janeiro, Francisco Alves,

\subsection{Depoimento}

ALMEIDA, Miguel de. "O brasileiro não tem fervor: entrevista com Antônio Callado". Folha de São Paulo, São Paulo 15 dez. 1982. p.4.

"O Brasil verdadeiro, na literatura de Callado" (entrevista.) Folha de São Paulo, São Paulo, 14 jul. 1981. p.48

ALMINO, José. O motor da luz. São Paulo, Editora 34, 1994

ANTÔNIO CALLADO: (entrevista). Revista do Livro, São Paulo (52):62-3, fev./mar 1984.

AQUINO FILHO, Jorge de. "O papel do intelectual é o participar: entrevista com Antônio Callado". Ele Ela,. Rio de Janeiro,13(12): 14-7 e 84-6, s.d. Edição especial.

COELHO, João Marcos. "Em nome da consciência" (entrevista com Antônio Callado). Veja. São Paulo, (410):3-6, 14 jul. 1976.

CUNHA, Paulo \& MORAES NETO, Geneton. "Intelectual não tem direito de se eximir" (depoimento de Antônio Callado). Inéditos, Belo Horizonte, (5):31-1, set/out. 1977.

EGYPTO, Luiz. "Falando Francamente" (entrevista com Antônio 
Callado). Folha de São Paulo. São Paulo, $1^{\circ}$ out. 1978. Folhetim. p.3-5.

ESCOBAR, Pepe "A política da perplexidade" (debate com Antônio Callado e outros intelectuais). Folha de São Paulo, São Paulo, 23 de out. 1983. Folhetim, p-4-5.

HOUAISS, Antônio, coord. Literatura. In: Ciclo de debates do Teatro Casa Grande. Rio de Janeiro, Inúbia, 1976 p.168-202.

LEITE, Lígia Chiappini M. "Entrevista com Antônio Callado). In: Zílio, Carlos e outros. Artes Plásticas. Literatura. São Paulo, Brasiliense, 1982 p.235-67. (O nacional e o Popular na Cultura Brasileira)

TOSTES, Otávio. "toda cultura é popular" (depoimento de Antônio Callado). Cadernos do Terceiro Mundo. Rio de Janeiro, 6(60): 20, nov. 1983

\section{Obras sobre o autor}

ATHAYDE, Tristão de. Prefácio. In: CALLADO, Antônio. Assunção de Salviano. 2. ed. Rio de Janeiro, Civilização Brasileira, 1960. P.3-8 (Vera Cruz: Literatura Brasileira, 21)

ARRIGUCCI JR., Davi. "O baile das trevas e das águas". In:

Achados e perdidos. São Paulo, Polis, 1979. P.59-75. (Estética, 3)

ARRIGUCCI JR., Davi e outros. " Jornal, realismo, alegoria (Romance brasileiro recente)". In:__ Ficção em debate e outros

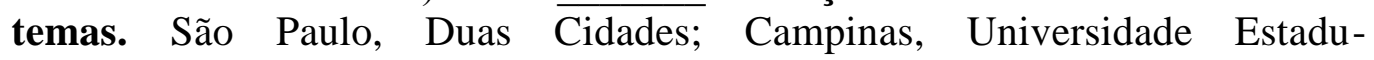
Al de Campinas, 1979. p.11-50. (Remate de Males, 1)

DALCASTAGNÈ, Regina. O espaço da dor. O regime de 64 no romance brasileiro. Brasília, Editora Universidade de Brasília, 1966.

GULLAR, Ferreira. "Quarup" ou Ensaio de deseducação para brasileiro virar gente". Revista Civilização Brasileira. Rio de Janeiro, 3(15):251-8, set. 1967.

HECKER FILHO, Paulo. "O romance justificado". O Estado de São Paulo, São Paulo, 21 set. 1968. Suplemento literário, p.6.

LEITE, Lígia Chiappini M. Antônio Callado: seleção de textos, 
notas, estudos biográfico, histórico e crítico e exercícios. São Paulo, Abril Educação, 1882. (Literatura Comentada)

. "País novo, coração decrépito". Leia Livros, São Paulo, 5(50):16, set. 1982.

"Quando a pátria viaja: uma leitura dos romances de Antônio Callado". In: ZÍLIO, Carlos e outros. Artes Plásticas e Literatura. São Paulo, Brasiliense, 1982 p.129-243. (O Nacional e o Popular na Cultura Brasileira)

LEITE, Paulo Moreira. "Xingu de Ipanema". Veja, São Paulo, (720): 130, 23 jul. 1982.

MARTINS, Edilson. "O furacão sopra. As pétalas caem”. In:

Nós, do Araguaia: Dom Pedro Casaldáliga, bispo da teimosia e da liberdade. Rio de Janeiro, Graal, 1979. p.45-50. (Eu, 4).

MARTINS, Heitor. "Serafim Ponte Grande". In:__. Oswald de Andrade e outros. São Paulo, Conselho Estadual de Cultura, /1973./ p.41-57. (Ensaios, 81)

MEDEIROS, Benício. "O Brasil profundo de Antônio Callado". Isto É, São Paulo, 5(227):56-7, 29 abr 1981

MEDINA, Cremilda. “ Brasil, por Callado, paixão que se traduz em romance”. O Estado de São Paulo, São Paulo, 2 set. 1984. p.32.

OLIVEIRA, Franklin de. "Com a mesma fúria das onças". Isto É, São Paulo, 5(227):56, 29 abr. 1981.

SILVERMAN, Malcolm. "A ficção em prosa de Antônio Callado". In: - Moderna ficção brasileira: ensaios. Trad, João Guilherme Linke. 2.ed. Rio de Janeiro, Civilização Brasileira; Instituto Nacional do Livro, 1982. p.19-33.

SODRÉ, Nelson Werneck. “O momento literário”. Revista Civilização Brasileira, Rio de Janeiro, 3(15):213-28, set. 1967.

\section{Geral:}

ABENSOUR, M. O Novo espírito utópico. Campinas, UNICAMP,1990.

ADORNO, Theodor. "Sartre e Brecht engajamento na literatura". In: CARDOSO, Fernando Henrique e outros. Cadernos de “Opinião”, v2 Rio de Janeiro, Inúbia, 1975. p.28-37.

AGOSTINHO, Pedro. "Kwarip: mito e ritual no Xingu". São Paulo, Epeu, Editora da Universidade de São Paulo, 1974. 
ALIGHIERI, Dante. "La divina commedia"(intr.. e notas de Natalino Sapegno), Milão/Nápoles, Riccardo Ricciard,/1957/. (La Letteratura Italinana: Storia e Testi, 4)

ALVIM, Thereza Cesário. "Sem querer, o imperialismo preparou no exílio uma geração altamente qualificada para dirigir os destinos dos países que a baniram" (entrevista om Francisco Julião). Status, São Paulo (61):20-4 e 127, ago. 1979.

OS ANOS 60: A DÉCADA QUE MUDOU TUDO. São Paulo, Abril, s.d.

"Os anos 70 comportamento". Folha de São Paulo, São Paulo, 30 set. 1979 Folhetim, p.1-16.

"Os anos 70 pensamento político". Folha de São Paulo, São Paulo, 7 out. 1979 Folhetim, p.1-20.

ARRAES, Miguel e outros. Palavra de Arraes, Rio de Janeiro, Civilização Brasileira, 1965.

AUERBACH, Erich. Mimesis: a representação da realidade na literatura ocidental. Trad. De Suzi F. Sperber. São Paulo. Perspectiva, 1971. (Estudos, 2)

AZEVEDO, Fernando de A cultura brasileira, 5. ed. Ver. Ampl. São Paulo, Melhoramentos; Universidade de São Paulo, 1971.

BAKHTIN, Mikhail. Problemas da poética de Dostoiévski. Trad. de Paulo Bezerra. Rio de Janeiro. Forense-Universitária, 1981. \begin{tabular}{l} 
Questões de $\quad$ Literatura \\
\hline do romance), São Paulo, Ed. Hucitec, 1988.
\end{tabular}

BETTO, frei. Batismo de Sangue: os dominicanos e a morte de Carlos Marighella. 2 ed. Rio de Janeiro, Civilização Brasileira, 1982.

BEnJAMIM, Walter. Magia e Técnica, Arte e Política. Ensaios sobre Literatura e História da Cultura. 7 ed, São Paulo, Brasiliense, 1994 (Obras escolhidas, volume 1)

BEZERRA, Gregório Memórias. Rio de Janeiro, 1979. 2v.

BLOCH, Ernest. Le príncipe esperánce. Paris, Gllimard, 1976, 1992, 1991.3t.

CARPEAUX, Otto Maria. História da literatura ocidental. Rio de Janeiro, O Cruzeiro, 1959-66 8v. 
CAVALCANTI, Pedro Celso Uchoa \& RAMOS, Jovelino, coord. De muitos caminhos. São Paulo, Livramento, 1978. (Memórias do Exílio, Brasil 194-19??, 1)

CÂNDIDO, Antônio. Literatura e sociedade: estudos de teoria e história literária. 2. ed. São Paulo, Nacional, 1967. (Ensaio, 8)

_. A educação pela noite e outros ensaios. 2 ed., São Paulo, Ática, 1989.

CARVALHO, Luiz Maklouf. Muheres que foram à luta armada. São Paulo, Globo, 1998.

CHAUÍ, Marilena. O que é ideologia. 4 ed, São Paulo, Brasiliense, 1981. (Primeiros Passos, 13)

COELHO, Teixeira. O que é utopia. 9 ed, São Paulo, Brasiliense, 1992. (Primeiros Passos, 12)

DREIFUSS, René Armand. 1964. Conquista do Estado: ação política, poder e golpe de classe. Trad. De Ayeska Farias e outros. 3. Ed. Petrópolis, Vozes, 1981.

ELIADE, Mircea. Images et symboles: essais sur le symbolisme magico-religieux. 5 ed. Paris, Gallimard, 1952.

FERNANDES, Millôr. Millôr no Pasquim. Rio de Janeiro, Nórdica, 1977.

FERNANDES, Millôr e RANGEL, Flávio. Liberdade, liberdade. Coleção Teatro de Millôr Fernandes, vol. 2. Porto Alegre, L\&PM, 1977.

FISCHER, Ernst. A necessidade da arte: uma interpretação marxista. Trad. de Leandro Konder. 2. ed. Rio de Janeiro, 1967.

FONSECA, Gondin da Assim Falou Julião... 2.ed. São Paulo, Fulgor, 1962.

FREIRE, Paulo. Educação como prática da liberdade. 9. Ed. Rio de Janeiro, Paz e terra, 1979.

FREIRE, Roberto e BRITO, Fausto. Utopia e paixão: a política do cotidiano. Rio de Janeiro, Rocco, 1984.

FREUD, Anna. O Ego e os mecanismos de defesa. Trad de Álvaro Cabral. 2. Ed. Rio de Janeiro, Civilização Brasileira, 1972. (Perspectivas do Homem: Psicologia, 85)

FREUD, Sigmund. “Esboço de psicanálise”. Trad. de José Otávio 
Abreu. In: Os pensadores. São Paulo, Abril Cultural, 1974. v.39. p.95-150.

GABEIRA, Fernando. O crepúsculo do macho: depoimento. 5 ed. Rio de Janeiro, Codrecri, 1980.

35 ed., Rio de janeiro, Guanabara, 1988.

$$
\text { O que é isso, companheiro? }
$$

Carta sobre a Anistia; A entrevista do Pasquim; Conversação sobre 1968. Rio de Janeiro, Codrecri, 1979.

GONDMANN, Lucien. A sociologia do romance. Tradução de Álvaro Cabral. 3 ed. Rio de Janeiro, Paz e terra, 1990.

GUEVARA, Ersnesto Che. Diário. Trad. De Olinto Beckerman. São Paulo, Centro Editorial Latino Americano, 1980.

GULLAR, Ferreira. "Considerações em torno do conceito de cultura brasileira”. Escrita Ensaio. São Paulo. 1(1):35-42, 1977.

HOLLANDA, Heloísa B. de \& GONÇALVES, Marcos A. Cultura e participação nos anos 60. São Paulo, Brasiliense, 1982. (Tudo é história, 41)

JAMESON, Frederic. Marxismo e forma. São Paulo, Hucitec, 1985. . O Inconsciente político. São Paulo, Ática, 1992.

JOSÈ, Emiliano e MIRANDA, Oldack. Lamarca: o capitão da guerrilha. 12. Ed., São Paulo, Global, 1989.

JUNG, Carl G. e outros. O homem e seus símbolos. Trad. De Maria Lúcia Pinho. 3 ed. ilustr. Rio de Janeiro, Nova Fronteira, s.d.

JUREMA, Abelardo. Sexta-feira 13: os últimos dias do Governo João Goulart. Rio de Janeiro, O Cruzeiro, 1964.

KAISER, Wolfgang. Interpretación y análisis de la obra literária. Trad. de Maria D. Mouton e V. G. Yebra. 4 ed. ver. Madri, Gredos, 1961.

LUKACS, Georg. Existencialismo ou marxismo. Trad. de José Carlos Bruni. São Paulo, Senzala, 1967.

Lisboa, Presença, s.d.

Teoria do romance. Trad. de Alfredo Margarido. 
LUKACS, Georg. ADORNO, T. W. e outros Polémica sobre realismo. Trad. de Irene L. Cusien e outros. 2. Ed. Buenos Aires, Tiempo Contemporáneo, 1972.

MARCUSE, Herbert. Eros e civilização: uma interpretação filosófica do pensamento de Freud. Trad. de Álvaro Cabral. 8. ed. Rio de Janeiro, Zahar, 1981. (Filosofia)

MARX, Karl e ENGELS, Friederich. Manifesto Comunista. Organização e introdução Osvaldo Coggiola. São Paulo, Boitempo,1998.

NORTE, Sérgio Augusto Queiroz. Bakunin: sangue, suor e barricada. Campinas, Papirus, 1988.

POUILLON, Jean. O tempo no romance. Trad. de Heloysa L. Dantas. São Paulo, Cultrix; Universidade de São Paulo, 1974.

SAID, Eduard W. Cultura e imperialismo. São Paulo, Companhia das Letras, 1995.

SARTRE. Jean-Paul. "O existencialismo é um humanismo". Trad. de Vergílio Ferreira. In: Os Pensadores. São Paulo, Abril Cultural, 1973. V.45. p.7-38.

SEGATTO, José Antônio e outros. PCB: memória fotográfica (1922-1982). 2. ed. São Paulo, Brasiliens, 1982.

SKIDMORE, Thomas. Brasil: Getúlio Vargas a Castelo Branco (1930-1964). Trad. de Ismênia T. Dantas e outros. 6. Ed. Rio de Janeiro, Paz e Terra, 1979.

SOARES, José Arlindo. A frente do Recife e o governo de Arraes: nacionalismo em crise - 1955/1964. Rio de Janeiro, Paz e Terra, 1982.

STEIN, Ernildo. Orfãos de Utopia. A Melancolia da Esquerda. Porto Alegre, Editora da Universidade do Rio Grande do Sul, 1996.

VENTURA, Zuenir. 1968. O ano que não terminou. A aventura de uma geração. Rio de Janeiro, Nova Fronteira, 1988. 